This item was submitted to Loughborough's Research Repository by the author.

Items in Figshare are protected by copyright, with all rights reserved, unless otherwise indicated.

\title{
Irish demons: English writings on Ireland, the Irish and gender by Spenser and his contemporaries
}

PLEASE CITE THE PUBLISHED VERSION

PUBLISHER

(C) University Press of America

VERSION

AM (Accepted Manuscript)

LICENCE

CC BY-NC-ND 4.0

\section{REPOSITORY RECORD}

Fitzpatrick, Joan. 2019. "Irish Demons: English Writings on Ireland, the Irish and Gender by Spenser and His Contemporaries". figshare. https://hdl.handle.net/2134/6240. 
This item was submitted to Loughborough's Institutional Repository (https://dspace.lboro.ac.uk/) by the author and is made available under the following Creative Commons Licence conditions.

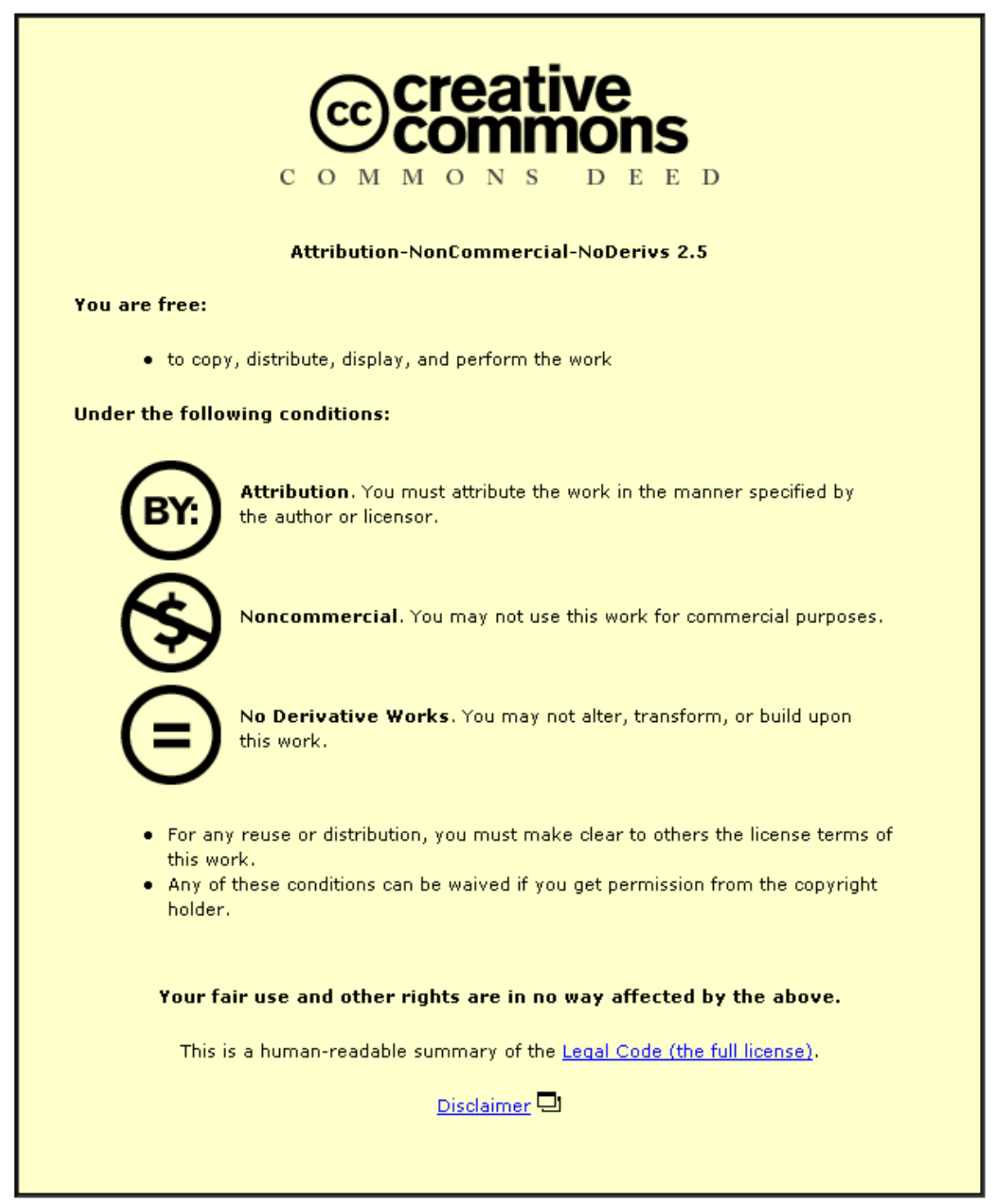

For the full text of this licence, please go to: http://creativecommons.org/licenses/by-nc-nd/2.5/ 


\section{Chapter 1}

Writing of Ireland: The "Supplication" and A View of the Present State of Ireland

Ireland was England's first colony and remains its last. The 800 years since the first English settlements can be divided into two distinct phases: the first incomplete colonization of the island by twelfth-century Anglo-Norman settlers, and the recolonization in the early modern period. The second phase manifested ruthless determination to succeed where the first phase was deemed to have failed.

Plantation as a policy began under Mary 1 with the confiscation of two-thirds of Leix and Offaly, the increasingly lawless regions west of the Pale. ${ }^{1}$ English men were encouraged to settle in Leix and Offaly but were forbidden on pain of forfeiture to sell or lease their land to any of Irish blood or birth. Under Elizabeth 1, however, financial frugality dominated. Like her father before her, Elizabeth was reluctant to undertake an expensive policy of state-funded colonization: it would instead become the enterprize of private speculators and adventurers. Two attempts to colonize parts of Ulster-one by Thomas Smith in 1572 and the other by Walter Devereux, Earl of Essex, the year after-failed miserably. Following the fall of the House of Munster an act was passed in 1586 for confiscation of the Earl of Desmond's estates. Among the New English granted land by the crown was the poet and government official Edmund Spenser. ${ }^{2}$ In 1580 Spenser had gone to Ireland as secretary to the newly appointed Deputy, Lord Arthur Grey de Wilton. When Grey was recalled, due to the excessive brutality and expense of his Irish policies, Spenser stayed in Ireland and wrote The Faerie Queene. Spenser left when the Munster plantation was overthrown in 1598.

Early modern English writings on Ireland frequently display anxieties about gender and use sexual difference as a metaphor for political, ethnic, and religious difference. The demonization of the Irish enemy weaves myths of savagery, including cannibalism, into a matrix of sexual deviance and disease, and transposes this onto the Irish landscape which is figured as menacing. The transition from an uncivilized state to an idealized, subdued condition is imaged as sexual conquest and this movement is evinced in writings by Spenser and his contemporaries. The main chapters of this book explore important ideological concerns at work in The Faerie Queene, concerns that are both reinforced and echoed in a range of early modern English writings on Ireland. As Andrew Hadfield points out "Spenser's life in Ireland does not mark him out as a particularly unusual Elizabethan writer. There are numerous examples of English writers going to Ireland out of necessity or desire" (Hadfield 1997, 20). Amongst those listed by Hadfield who "were connected to the Elizabethan civil service or military, often both" are Barnaby Rich, John Derricke and John Davies whose opinions on Ireland and the Irish feature in this book.

The prose tract $A$ View of the Present State of Ireland (hereafter the View) analyses the parlous state of Ireland and proposes how best to bring it to order 
under English rule. Nicholas Canny has suggested that the opinions expressed in the View are representative of those held by the New English involved in the colonial project in Ireland (Canny 1983, 10-11). It has long been assumed that the View was written by Spenser but recently this has been called into question. ${ }^{3}$ For our purposes, however, milieu supercedes authorship: whether Spenser or some other English colonist wrote the View is less important than the text itself as an example of early modern English opinion on Ireland.

Some time in the winter months of 1598 a New English planter penned an extraordinarily vehement attack against the Old English and Native Irish denouncing their brutality against the New English settlers in Ireland. "The Supplication of the Blood of the English most Lamentably Murdered in Ireland, Cryeng out of the Yearth for Revenge" (hereafter the "Supplication") was written during the Nine Years War, after the overthrow of the Munster plantation. Although the View was not published until 1633 it was probably written in 1596 and circulating in manuscript before its publication. Presumably the "Supplication" would also have been circulated in manuscript because, like the View, it would have aroused the interest of colonial groups in Ireland as well as associated parties in London. The "Supplication" is anonymous but, given the unclear initials at the end of the manuscript (apparently ' $T$. C.') and peculiarities of style and handwriting, its transcriber, Willy Maley, suggests that it may have been written by Thomas Cartwright, an Elizabethan puritan. Yet as Maley points out, and as with the View, the question of authorship is less important than "the general drift of New English Ideology" that the "Supplication" betrays (Anon. 1995, 10). This ideology is of particular interest to readers of Spenser. If the "Supplication" can be shown to consider the same issues at work in The Faerie Queene then we can perhaps see the degree to which Spenser shares the mind-set of other early modern colonists in Ireland.

The author of the "Supplication" speaks with the collective voice of the New English settlers. Like Spenser, T. C. was a resident of Cork who was forced to flee his land and property during the Munster rebellion. Both the "Supplication" and the View advise the queen on how best to deal with the conflict in Ireland during the 1590s and both display what Maley refers to as a barely submerged resentment of Elizabeth couched in frequent protestations of loyalty (Anon. 1995, 8). The View may have been censored because of the severity of opinions expressed in it and although we cannot tell whether the "Supplication" was intended for publication we can assume that had it been offered for immediate publication it would certainly have been considered dangerous material.

Maley calls the "Supplication" an early example of "English atrocity literature, rehearsing the myths of massacre which were to turn radical English thought resolutely against the Irish in the 1640s". As such it disseminated certain "planter myths, cultivated by a dominant minority at crucial historical moments, and intended for popular consumption in England and Ireland" (Anon. 1995, 7). Maley goes on:

This is no real mine of information for the social historian, or for the historian of contemporary politics and policies, but rather a rich seam of sources for intellectual and literary historians, eager to reconstruct the mental world of the Elizabethan planter. (Anon. 1995, 10) 
Analysis of the "Supplication" in the context of The Faerie Queene and the View suggests that it is possible to at least partially "reconstruct the mental world of the Elizabethan planter" by identifying the psycho-textual strategies of planter myths.

The attitude towards the landscape of Ireland and its inhabitants in the "Supplication" is typical of much of the planter rhetoric during this period in its ambivalence toward the former and hostility toward the latter. In the "Supplication" the land is represented variously as submissive, inherently wicked, bloodthirsty, wounded, and infected. At times T. C. claims that the land itself is malevolent, sometimes its inhabitants are the problem, and sometimes both conspire against the English. Throughout the "Supplication" there are references to the land and the Irish as cursed. The land is also presented as a victim, a passive receptacle for the savage Irish. If the land could be freed of the Irish people, T. C. asserts, "The curse of the one, will vanishe $w^{\text {th }}$ the distruction of the other" (Anon. 1995, 72). In the View Irenius tells Eudoxus that it is said of Ireland

that no purposes whatsoeuer are mente for her good, will, prosper or take good effecte, which wheather it proceed from the very Genius of the soile, or influence of the starres, or that Allmighty god hathe not yeat Appointed the tyme of her reformacion or that he reserueth her in this vnquiet state still, for some secrete skourge, which shall by her Come vnto England it is harde to be knowen but yeat muche to be feared (Spenser 1949, 43-44)

Eudoxus answers that this is superstition and that Ireland's problems are not the result of any supernatural agency but "proceed rather of the vnsoundnes of the Counsells and plottes, which youe saie haue bynne often tymes laied for her reformacions or of faintnes in followinge and effectinge the same ..." (Spenser 1949, 44).

In the "Supplication" there are ritualistic overtones to the spilling of English blood on Irish soil which may allude to the Catholic belief in transubstantiation: "for they thinke that land unhalloed, that hath not droncke of the bloode of $o^{\text {re }}$ poore Contrimen" (Anon. 1995, 32). The narrator recalls that Elizabeth's "noble and valiant" ancestors were suspicious of Ireland

least the soile should alter them; lest $y^{e}$ corruption of the Contry should infecte them as it hath done mightyly (so provident were they to for see that $\mathrm{w}^{\mathrm{ch}}$ should many yeares fall out after) They erected Castelles to Comaund the Citties to keepe them in obedience and awe ... (Anon. 1995, 41)

The country's Irish inhabitants are also said to be infectious and the narrator praises Lord Deputy Burowe (or Burgh) who, had he not met an untimely death, would have kept them under control: "They had been kepte $w^{\text {th }}$ in the limittes of their owne holdes and fastnes. They had not crawled out of their owne desertes, out of the bedde of their owne venime, to infecte other places $w^{\text {th }}$ poyson" (Anon. 1995, 20). Yet elsewhere T. C. tells Elizabeth "Yo ${ }^{\text {re }}$ estate in Ireland is nowe a bleeding: if yo" will upholde it, seeke in time to it" (Anon. 1995, 20). That the land is imagined to consume but also lose blood is indicative of the ambivalence toward Ireland in English writings from the period which regularly construct the land as both aggressor and victim. 
Agricultural metaphors pervade New English rhetorical solutions for the Irish 'problem' in the early modern period. Of course the employment of such metaphors can be explained by the reality that land was Ireland's most valuable resource and as such was fully exploited by the colonizers. In A Discovery of the True Causes Why Ireland was Never Entirely Subdued John Davies describes the Protestant planter as husbandman, Ireland as a land which must be broken before it can be cultivated, and the New English planters as good seeds which should replace Irish weeds:

For, the Husbandman must first breake the Land, before it bee made capeable of good seede: and when it is thoroughly broken and manured, if he do not forthwith cast good seed into it, it will grow wilde againe, and beare nothing but Weeds. So a barbarous Country must be first broken by a warre, before it will be capeable of good Gouernment; and when it is fully subdued and conquered, if it bee not well planted and gouerned after the Conquest, it wil eft-soones return to the former Barbarisme. (Davies 1612, B1v-B2r)

The sexual connotation of casting seed is typical of much of the planter rhetoric of this period in its fusion of agricultural and sexual metaphor. In the View Irenius claims that reformation should begin with the eradication of the rebellious Irish, here figured as unwanted vegetation:

for all those evills muste firste be Cutt awaie by a stronge hande before anie good Cane be planted, like as the Corrupte braunches and the vnholsome boughes are firste to be pruned and the foule mosse clensed and scraped awaye, before the tree cane bringe forth anye good fruite (Spenser 1949, 148)

Throughout the "Supplication" T. C. refers to the Irish as weeds that must be uprooted, or at least suppressed, if the English Planters are to survive:

Weedes they are O Queene, the naturall plants of theire owne soyle; the earth of Irland is their naturall mother, a stepdame to us: you can never soe cherishe us, what care soe ever $\mathrm{yo}^{\mathrm{u}}$ take about our plaintinge, unlesse yo $\mathrm{u}^{\mathrm{u}}$ seeke to supplant them, or at the least to keepe them downe from theire full groweth, but that they will overshadowe us, but $y^{t}$ they will keepe the warmethe of the sonne from us. (Anon. 1995, 38)

The land is here figured as malevolent for it has a strong familial and nurturing relationship with the rebellious Irish. When T. C. instructs Elizabeth on how best to put down rebellion her troops are imagined as farmers and, as in the View, the metaphor urges extreme measures: "Out wth yore mowers: geve them sythes in their handes: lett them make smothe worke; cutt downe all before them: for all that are lefte are weedes" (Anon. 1995, 71). The author goes on to announce that Ireland will be an ideal nursery for England once the weeds have been destroyed:

Lett the feete of $\mathrm{yo}^{\mathrm{re}}$ forces treade and trample downe these bryars, that will not suffer $\mathrm{yo}^{\text {re }}$ plantes to prosper: Lett them weare $\mathrm{w}^{\text {th }}$ their heeles the very rootes out of the earth that they springe no more: soe shall yo ${ }^{u}$ make Ireland a florishinge nursery for England, able to yeald yo ${ }^{u}$ if neede should requier, graftes to supply gappes in 
England, if ever there should be any made: as we pray god, there never may be, and hope in Christ there never shalbe . . . (Anon. 1995, 72)

The land might be cultivated were it not for the Irish: "The land is a blessed land, were the people themselves blessed, could they be brought either by perswasion, or compulsion, that god might bless them" (Anon. 1995, 72). In contemporary religious thinking, of course, the Irish are 'unblessed' because they are not Protestant. These 'weeds' must be uprooted if the colonists are to plant strong and healthy roots in Ireland:

If it be weeded it wilbe a florishinge cuntry: If it be reformed (as it only ought to be), from the heade to the foote, in godes matters, as well as in mans (for $w^{\text {th }}$ out the reformation begine from thence, that $w^{\text {ch }}$ follows can not happely $p[$ ro]ceede) it wil no doubte be a blessed comon welthe. (Anon. 1995, 72)

Those who will bring about the Reformation of Ireland are husbandmen who will tend the soil in order to make it healthy and who will cut down stubborn Irish Catholics as a matter of course. The notion that Ireland must be husbanded carries the kind of sexual associations fully explored by Luke Gernon in his A Discourse of Ireland (1620): "It is nowe since she was drawne out of the wombe of rebellion about sixteen yeares, by'rlady nineteen, and yet she wants a husband, she is not embraced, she is not hedged and diched, there is noo quicksett putt into her" (Falkiner 1904, 349-50). ${ }^{4}$ The trope of the colonizer as husbandman and the reference to enclosure is a punning link between the cure of a 'husband' and 'husbandry' as a synonym for farming and careful management.

Gender is crucial to New English rhetoric about Ireland. In the "Supplication", and as we shall see later in The Faerie Queene, land is imagined as female and the metaphor of husbandry is utilized with its various connotations of married manhood, careful management, and tilling of the soil. T. C.'s appeal to national loyalty depicts England as a good mother. The Old English have not only forgotten their English natures but also the loyalty they owe to Mother England:

They were in the former tymes, as wee are now, meere Englishe in habite, in name, in nature. They nowe retaine nothinge of that they were but the bare name. Our apparell is scorned of them; $o^{\text {re }}$ nature hated; o ${ }^{\text {re }}$ selves abhorred. And why? because the blood of theire Irishe mothers, hathe wasted away the naturall love they bare to theire mother England; the aleagance they swore to theire prince; the dewtie they ought to god. (Anon. 1995, 33)

Allegiance to England and Elizabeth is as important as allegiance to God and to turn away from either constitutes an abandonment of religious faith. Ireland is a bad mother who nurtures the strength of her wayward children and behaves like a wicked stepmother to the English. Linked to the blame levelled at a female Ireland is the notion that Irish mothers are seditious and encourage disobedience to country, prince, and god. The Irish nurse is said to transmit her seditious nature to the children of the English who "suckte theire conditions from the teates of their Irish nurses" (Anon. 1995, 33). Irish women are blamed for the conflict between England and Ireland which is presented as a conflict between two women. T. C. calls upon 
Elizabeth to ensure the future security of England-the mother of all English men and women including Elizabeth herself-before she dies:

our humble suite $\ldots$ is, that $\mathrm{yo}^{\mathrm{re}}$ motherly affection wilbe such towards yo ${ }^{\mathrm{re}}$ contry, and ours; towards the Comon mother of us all, as that the foundacon of her prosperitie and flourishinge estate, may by you in yo ${ }^{\text {re }}$ glorious and memorable raigne, be soe surely layed, that noe storme may ever be able to overthrowe hir, no tempest to shake her. (Anon. 1995, 56)

England is also referred to as a nursing mother in the View when Eudoxus expresses astonishment that the Old English should want to adopt Irish surnames: "Coulde they euer Conceaue anye suche divillishe dislike of theire owne naturall Contries as that they woulde be ashamed of her name and bite at the dug from which they sucked liffe" (Spenser 1949, 116).

In New English rhetoric on Ireland, negative gendering co-exists with depictions of Ireland as vulnerable, marking a transition from land-as-enemy to land-as-victim. The representation of England as a mother suggests nurturing, security, and loyalty. No doubt the shape and juxtaposition of the two land masses-which on a map appear like child and embracing parent-aided this metaphor. ${ }^{5}$ The construction of Ireland as a sister to England similarly casts a positive light on the relationship and suggests familial fidelity as a strong bond between the two. T. C. warns that if Elizabeth does not follow his advice then she cannot rely on the loyalty of Ireland and will forego the strong familial bond that should exist between them: "Your crowne of Ireland shall never stand steedye upon yore head: nor England shall never stand assured to have Ireland a faithfull neighbour: much lesse a kinde and lovinge sister" (Anon. 1995, 71). A similar feminization of the land occurs in Thomas Blenerhasset's A Direction for the Plantation in Ulster with his plea to Prince Henry that English subjects colonize the desolate county of Ulster:

Dispoyled, she presents her-selfe (as it were) in a ragged sad sabled Robe . . . Fayre England, she hath more people then she can well sustaine: goodly VIster for want of people vnmanured, her pleasant fieldes and rich groundes, they remaine if not desolate, worsse. (Blenerhasset 1610, A2r-A2v)

Again, as evident in the "Supplication", the View, and Davies's A Discovery of the True Causes, Ireland is depicted as a country full of potential which could be harnessed by cultivation. In conclusion, Blenerhasset makes "an exortation to England" that she help Ulster, the daughter of her sister Ireland:

Fayre England, thy flourishing Sister, braue Hibernia, (with most respectiue termes) comendeth vnto thy due consideration her yongest daughter, depopulated VIster: not doubting (for it cannot but come vnto thy vnderstanding) how the long continuance of lamentable warres, haue raced \& vtterly defaced, whatsoeuer was beautifull in her to behold . . . (Blenerhasset 1610, D1v)

As well as stressing the importance of the familial duty and fidelity England must show Ireland, representing Ulster as a younger niece suggests that the county is vulnerable. As a result of her disfigurement by the warring Irish, Ireland needs the 
Fitzpatrick, Joan. 2000b. Irish Demons: English Writings on Ireland, the Irish and Gender By Spenser and His Contemporaries. Lanham. University Press of America.

protective influence of England as a stronger and more experienced entity to govern her.

Whilst for Blenerhasset England is powerful and prosperous, the author of the "Supplication" depicts England as a female victim of Irish sexual aggression:

Weepe England, mourne, lament, not the losse of us, but the losse of thy honor; not $\mathrm{o}^{\text {re }}$ destruction but thine owne disgrace. Thow that wast woonte to checke mightie monarches, art nowe almost mated and maistered by a roote of base trators . . . (Anon. 1995, 21)

Dishonoured, "mated" and "maistered", England has fallen from colonial ruler to sexually-dominated subject. Anxiety about social control and miscegenation is also evident in the View where Irenius condemns fostering and marriage between the Old English and Native Irish because the relationships transgress sexual, political, and ethnic boundaries. This anxiety runs through The Faerie Queene and underlies the analysis undertaken in the following chapters.

In early modern English writings on Ireland the process of colonialism is often described using sexual metaphors but literal union of colonizer and colonized is always denounced. Real sexual relations threaten the balance of power: the 'penetration' must remain metaphorical. Related to the notion of England as a mother is that of Elizabeth as mother of the English Church and people. ${ }^{6}$ Although T. C. appeals to the "motherly affection" of Elizabeth toward her English subjects the barely submerged hostility against her, detected by Maley, is evident in the criticism that Elizabeth has not always been a good mother.

Many New English in Ireland saw the Munster rebellion coming but "These feares we neglected, these daungers wee adventured upon the assurance of yore princely care and motherly affection towardes us, upon the assurance of yore royall power and readie will to protect us" (Anon. 1995, 12). Elizabeth is criticized for what is perceived as neglect of the New English because the motherly protection and attention they deserve has been squandered on their enemies: "Yore facilitie $O$ Queene, hath ben too much abused, to the strenghtninge of yore enemies, to the discoraginge of yore subiects" (Anon. 1995, 13). Similarly in the View Elizabeth is implicitly criticised for being too ready to show compassion to the Irish, as when she recalled Lord Grey and so interrupted the process of Reformation:

He noble Lord eftsones was blamed the wretched people pittied . . . all former purposes weare blanked, the governour at a baye and not onelye all that greate and longe Chardge which she had before bene at quite loste and Cancelled, but allso all that hope of good which was even at the dore put backe and Cleane frustrate. All which wheather it be trewe or not your selfe Cane well tell (Spenser 1949, 160)

Fairyland, like Ireland, is a place under the direct influence of a powerful woman who should not be so elusive. Although Elizabeth's presence was conspicously lacking in Ireland it pervades Spenser's poem. It is not too fanciful to hear in 'faerie' a pun on 'very' since The Faerie Queene is a poem about 'the very queen'. 
Elizabeth's monarchial femininity is further underlined when God is presented as a father or lover of Elizabeth "whoe hath kepte you as his onely dearlinge, as the apple of his eye, under his wynges, even in the most desperat resolutions of wicked traytores" (Anon. 1995, 49). The urging of political loyalty, via allusions to sexual fidelity, raises the possibility of Elizabeth's infidelity-to God and by extension to English Protestantism—which might be considered an insult to the queen.

Irish women are particularly dangerous enemies because, like Duessa and Acrasia in The Faerie Queene, they use their sexuality to corrupt men who would otherwise be faithful subjects. At the very least the English have made themselves degenerate by their intermarriage with Irish women, which "matches make yore selves slaves unto them that should be slaves to you: undoe yore Contriemen; hazard the whole estate of the Comon wealthe" (Anon. 1995, 32). The sexual enslavement of the English makes them politically impotent. The implication is that although all women should be socially subordinate to their husbands, Irish women should be doubly subordinate because of their religious and ethnic inferiority. Irenius and T. C. put the burden of guilt onto the women. Irenius asks "how cane suche matchinge but bringe forthe an evill race seinge that Comonlye the Childe takethe moste of his nature of the mother . .." (Spenser 1949, 120) and T. C. reasons that it is Irish women who have metamorphosed these Englishmen: "what hath turned them from Englishe wch they sounde in name, to Irishe wch they appeare in nature? from men to monsters? but theire Irishe matches?" (Anon. 1995, 33). Like the malevolent females in The Faerie Queene, Irish women achieve their goals by sexual seduction and subterfuge:

They are professed patronesses, O Queene, for all ofenders: intollerable is the husbandes life, yf their desire be not satisfied: They lye in the bosomes of $o^{\text {re }}$ greate men, to maintaine the cuttinge of $o^{\text {re }}$ throats; to prevent the devises of $o^{\text {re }}$ governors; to hinder the cutting of $o^{\text {re }}$ enemies. (Anon. 1995, 32).

They are figured as demons because of the change they effect in English men, transforming them "from men to monsters" (Anon. 1995, 33).

Anxiety about the sexual power of Irish women who are capable of transforming men into monsters is part of a general fear of the Irish expressed in texts of the period via a paradigm of sexual relations. T. C. is particularly severe in his condemnation of the rebel Rory Oge (Rory Óg O'More of Leix):

how happy had England been, if he had ben distroyed in his cradell (for past it, he was not in his fathers rebellion) yo $^{\text {re }}$ highnes had avoyded halfe this troble by the death of that one whelpe, who then sucked milke, nowe suckes bloode: The Cuttinge of, of him in his Swadlinge cloutes, had nowe cutt yo ${ }^{\text {u }}$ of halfe yo ${ }^{\text {re }}$ charge: The distruction of that one bratt of a traytor, at that tyme, had spared yo ${ }^{u}$ now ten thowsand men. (Anon. 1995, 60)

The infant fed on Irish breast milk will be weaned on English blood. Like many New English texts on the Irish the "Supplication" uses metaphors of generation and nurture gone awry. T. C. warns Elizabeth that "There be a greate many brattes of greater daunger nowe springine" that will cost her the lives of many men (Anon. $1995,60)$. Irish women figure large in this fantasy of perverted nature: 
Shee that at night suckes from yo ${ }^{\text {re }}$ bosome, what soever the store house of yo ${ }^{\text {re }}$ harte containeth, laboreth in the morninge (as if she were $w^{\text {th }}$ childe) untill she have delivered it either to her brother, her sonne in lawe, or some of her kinsmen. (Anon. $1995,30)$

Here information—presumably military and/or political—is unnaturally sucked by the Irish witch/babe and delivered to the enemy. The ability of breast milk to transmit nature and character from mother to child is a great concern for Irenius in the View. He denounces the practice of breast feeding and fostering by Irish women as "two moste daungerous infeccions" and claims that in the act of suckling, English children will "drawe into themselues togeather with theire sucke even the nature and disposicion of theire nurses" (Spenser 1949, 119). References to Irish breast feeding and childbirth in the "Supplication" suggest that Irish women produce a monstrous and uncontrollable progeny which will continue to rebel against New English Protestants. The land is a 'mother' to any colonist in that it is expected to provide sustenance, and their fantasies of good and bad nursing can usefully be related to Melanie Klein's work on infantile splitting of 'good' and 'bad' breast as a consequence of unsatisfying or anxious feeding. ${ }^{7}$ The power of threatening metaphor reaches a peak in T. C.'s description of the son of the Earl of Clancare (McCarthy Mór) as a "man-devouring beast" and as we shall see later suggestions that the Irish are cannibals or vampires pervade New English writing of the period.

In the "Supplication" the author's claim that allegiance to England and Elizabeth is the same as allegiance to God positions God as an English Protestant. The English Protestants should have known, says T. C., that those who had rebelled against God would also rebel against the English (Anon. 1995, 22). God is on Elizabeth's side and the Reformation of Ireland is "godds cause" (Anon. 1995, 18). Furthermore, God has brought this destruction upon the New English Protestants because they were not severe enough in the implementation of Protestant Reform in Ireland: "We have contemned his honor, and therefore hath he most iustlie throwen $\mathrm{o}^{\text {re }}$ honor in the duste for the feete of $o^{\text {re }}$ enemies to trample on" (Anon. 1995, 22). The Munster rebellion is seen not as a victory by the Irish over the English but rather as a lesson sent by God from which the English can learn. The Irish rebellion is here given biblical proportions and, like the story of Satan's fall, is imparted to humanity by divine revelation. Appropriate revenge is also conceived in biblical terms: Elizabeth wields the sword of justice with a mandate from God himself to avenge the deaths of the English (Anon. 1995, 12). The author speaks with the collective voice of the New English victims of the Munster rebellion who

humblie Craveth at the hands of yo ${ }^{\text {re }}$ sacred Ma: ${ }^{\text {tie }}$ (unto whom god hath comitted the sword of lustice to punishe the offender, and upon whom he hath imposed a care and charge for the mainten[a]nce and defence of the innocent) To revenge the monstrous rapes of many poore forlorne widdowes, and the bloody murders of many yo ${ }^{\text {re }}$ faithfull subiects ... (Anon. 1995, 12)

According to T. C. papists are inherently incapable of serving God or Elizabeth: "The divell will never be a true servant to god; nor an Irish papist (upon whom the naturall hatred of his Contry, and the old inveterate hate of his religion setts an edge) a true subiect to Queene Elizabeth" (Anon. 1995, 52). Because the Irish are "the professede champions of the Pope" T. C. urges Elizabeth to be "the ever vowed 
Champion of god, to defend his honor and his cause, that ever defended you and yores" (Anon. 1995, 50). The Catholic Irish, T. C. claims, know that religion is political:

in theire irreligious assemblies, and wicked prayers, they pray for the strenghtninge of the Popes forces, of them that fight for the faith (as they tearme it) and for the confusion of the Queene of England ... (Anon. 1995, 42)

Just as the Irish are roused to rebellion by their priests with "their mutinous mutteringes, their uproares, their disorders" (Anon. 1995, 68), so the English troops will have divine guidance: "God will direct their counsells; protect their personnes, effect their devises" (Anon. 1995, 71). There is a hint here of the chivalrous knight directed by God and by the justice of his cause. In contrast, the Irish are considered to be more barbaric than the infidel:

Never shall yo ${ }^{u}$ reade in the stories of the Gothes and Vandalles, in the recordes of the Turkes and Infidells, in the most barbarous and cruell warres that ever were, suche brutishe crueltie, such mounsterous outrage. $\mathrm{O}$ that $\mathrm{yo}^{\mathrm{re}}$ highnes might $\mathrm{w}^{\text {th }}$ out hazard to yo ${ }^{\text {re }}$ royall person have seen the demeanour of those savage beasts, for men we can not call them, whose doinges shewe such Contrarietie to manhoode. (Anon. 1995, 18)

As Richard McCabe comments of Book 5 of The Faerie Queene "The Christian/Paynim dichotomy provides Spenser with a means of organising his political allegory. The 'pagans' of romance fiction are the Catholics of reformed politics" (McCabe 1989a, 112). The same connection is made by Irenius in the View: "they are all Papistes by theire profession but in the same so blindelye and brutishly enformed for the moste parte as that ye woulde rather thinke them Atheists or infidels" (Spenser 1949, 136). By associating Irish Catholics with non-believers and Muslim enemies both the "Supplication" and the View marginalize them as religious aliens.

The notion of Protestantism as truth and Catholicism as falsehood permeates the "Supplication". The author implores God that the rebellion of the Irish may be sufficient warning for the English "to be more zealous hereafter in the erecting of true religion" (Anon. 1995, 52). T. C. urges that preachers denounce Catholicism in the pulpit:

O yee preachers; bestowe yo ${ }^{\text {re }}$ eloquence herein; it is gods cause, and therefore yo ${ }^{\text {re }}$ business to sett it forward; They pretended religion; $\mathrm{p}$ [ro]voke yee $\mathrm{yo}^{\mathrm{re}}$ hearers to the maynte[na]unce of true religion: (Anon. 1995, 58)

All good order, loyalty, and duty depend upon Irish Catholic conformity to the Protestant faith and ensuring this should be the first task of Elizabeth: "Begine you to bend them to god, and god will make them simply in singlenesse of harte to bowe to you" (Anon. 1995, 65). Only by securing the Protestant religion in Ireland can Elizabeth be confident of the security of her state and the destruction of her enemies. The Protestant religion is the only true religion and as such is God's cause: "Yore zeale shall drawe god from heaven to fight for you, as their contempt of him, and his word hath drawen his vengeance uppon themselves, and us" (Anon. 1995, 66). The 
enemies of Protestants are considered the enemies of truth: "They that have ever been defacers of the truthe, defacers of the gospell, will never lifte hand for the defence either of truthe, or gospell" (Anon. 1995, 70).

According to T. C. Ireland was a gift from God to the New English Protestants so they could assert the gospel and defeat Roman Catholicism, but they failed him by not asserting the true faith strongly enough:

We did not in $o^{\text {re }}$ Government seeke his glorie; in $o^{\text {re }}$ reformations we leaste attempted the reformation of his house, of his Churche: wee halted our selves $w^{\text {th }}$ the infidells in religion. . . . God gave us the land to erect therein the Gospell: he sett us up and threwe downe them, to the ende he would by us pull downe their idolatrie: He gave us the sword to swaye that his word might beare sway amongst them. (Anon. 1995, 21-22)

God's main aim, it seems, was to defeat Catholic idolatry. In the opening paragraph of the "Supplication" the crimes of the Irish are listed and they are denounced as "that faithlesse, unmercifull, Idolatrows, and unbeleving nation" (Anon. 1995, 12). T. C. warns that "Untyll you ridd Idollatry out of the Contry . . . never looke to banishe rebellion" (Anon. 1995, 65). It is not only the rebels who should be sought out and punished but all the Irish, broadly characterized as idolaters. English troops should "scoure the cuntry, beate downe Idolatrye (for Idolators they are all) . . . if one be a subiect amongest them, ther is never a rebell" (Anon. 1995, 71). In the commentary to the May eclogue of The Shepheardes Calender the trappings of Roman Catholicism are dismissed by E. K., probably a Spenser persona, as "trifles . . . the reliques and ragges of popish supersition" and Catholics themselves condemned as superstitious papists who "put no smal religion in Belles: and Babies .s. Idoles: and glasses .s. Paxes, and such lyke trumperies" (Spenser 1943,58$).^{8}$ T. C. advocates justice, warns against mercy, and encourages the destruction of idolatry at its source. Since he believes that idolatry is inherent to the Irish, there is no hope of reforming them:

Yo $^{\text {re }}$ mercy will not change theire manners; yo ${ }^{\text {re }}$ benefitts be they never soe aboundantly powred upon them, will never wash away the corruption of their nature; nor the blessings of god . . . cannot move them to forsake the rebellion that buddes from their supersticious Idolatry. It is the fruite of their religion: God hath in his lust ludgm $^{\mathrm{t}}$. geven it leave to growe to this height, because yo ${ }^{\text {re }}$ ministers never endevoured to plucke up the roote. (Anon. 1995, 51)

Only force offers the solution of compelled conversion on pain of death:

let them feele the force of such compulsion, that either they may be forced to come to the true god for a refuge, or els for their rebellious hartes to perishe $\mathrm{w}^{\text {th }}$ Idoll. (Anon. 1995, 72-73)

In A New Description of Ireland Barnaby Rich describes the Irish as "rude, vncleanlie, and vnciuill, so they are very cruell, bloudie minded, apt and ready to commit any kind of mischiefe" (Rich 1610, D4r). This conception of the Irish as savage permeates the "Supplication" and can also be traced through much of the 
Fitzpatrick, Joan. 2000b. Irish Demons: English Writings on Ireland, the Irish and Gender By Spenser and His Contemporaries. Lanham. University Press of America.

English writing on Ireland of the period. Rich thinks that Irish savagery is due not to their inherent nature but rather to

their education, that they are trained vp in Treason, in Rebellion, in Theft, in Robery, in Superstition, in Idolatry, and nuzeled from their Cradels in the very puddle of Popery. (Rich 1610, D4r)

A fusion of Irish culture and Roman Catholicism has encouraged rebellion against Elizabeth and her representatives, yet the primary evil is Catholicism:

This is the fruits of the Popes doctrine, that doth preach cruelty, that doth admit of murthers and bloudy executions; by poisoning, stabbing, or by any other maner of practice howsoeuer: the pope teacheth subiects to resist, to mutinie, and to rebel against their Princes. (Rich 1610, D4r-D4v)

In his introduction to the "Supplication" Maley claims that unlike the View, which focuses its attack primarily on the Old English community, the "Supplication" is an attack against both the Old English and the Native Irish (Anon. 1995, 3). Maley also claims that whilst Spenser "displayed a remarkable indifference in matters of religion during his discussion of Irish reform", T. C. "places religious difference in a position of supreme prominence in his tirade against all things Irish, or, in his eyes, hibernicised" (Anon. 1995, 4-5). Although the View certainly aims its attack at the Old English, their fault is their association with all things Irish and Catholic. The attitude toward Irish Catholics evident in the "Supplication" can be found in The Faerie Queene, the View, and other contemporary writings on Ireland. These texts reveal prejudices against the Catholic Irish, women in general, and Irish women in particular. Although T. C. screams for revenge against the savage enemy and writers like Rich explicitly condemn them, Spenser's allegorical attack is more subtle and arguably more invidious.

Why should the "Supplication", an anonymous prose tract written in the late 1590s, be of interest to readers of The Faerie Queene? The answer is that the "Supplication" provides a fascinating insight to the opinions-albeit some of the most extreme opinions - held by a New English planter in Ireland and that Spenser belonged to this embattled class of aliens. There are similarities in the overall ideological thrusts of The Faerie Queene, the View, and the "Supplication". All are preoccupied with a sense of mutual alienage between English and Irish political, ethnic, and religious norms and all are imbued with anxiety about women. Commentary on Irish women, who being Catholic Irish and female are doubly suspicious, is evident in all these as is the figure of Elizabeth, whose troubling presence is pervasive. Both Spenser and the author of the "Supplication" had settled in Cork but were ousted from their homes in the Munster rebellion. Both the "Supplication" and the View urge the reluctant queen to subdue Ireland, and in both there is a barely submerged hostile edge to the pleading. If we attune our ears to particular parts of the poetic allegory of The Faerie Queene it is possible to hear the same concerns being voiced in an artistically displaced yet quite discernably urgent form.

Since Freud's discovery of the unconscious, and more especially since poststructuralism's analysis of the inflated 'author function', the survival of a poet's 
explanation of his work has been held to be something of a mixed blessing. Without mining Spenser's comments on his own work for too much detail, we may at least note that Spenser assumed his readers would read his poetry as allegory: there is usually a parallel story running alongside, and perhaps just beyond sight of, the narrative surface. In a letter to his friend Walter Raleigh, Spenser refers to the allegory of The Faerie Queene as a "darke conceit" and tells Raleigh that some will criticize him for his use of allegory:

To some I know this Methode will seeme displeasaunt, which had rather haue good discipline deliuered plainly in way of precepts, or sermoned at large, as they vse, then thus clowdily enwrapped in Allegoricall deuises. (Spenser 1977, 737)

Spenser reveals "the general intention and meaning" of his poem to his friend because he is keen to avoid "gealous opinions and misconstructions" but his disclosure cannot be more detailed precisely because allegory is used by Spenser to cloak his commentary on sensitive political issues.

In a dedicatory sonnet to Lord Burghley it is clear that Spenser expects Burghley to read his allegory and explicate its 'deeper sense' which is hidden from the 'common view':

Vnfitly I these ydle rimes present, The labor of lost time, and wit vnstayd; Yet if their deeper sence be inly wayd, And the dim vele, with which from comune vew Their fairer parts are hid, aside be layd. Perhaps not vaine they may appeare to you. (Spenser 1977, 741)

In another dedicatory sonnet addressed to the Earl of Ormond and Ossory, Spenser emphasizes his poem's savage origins. The Faerie Queene is a "wilde fruit, which saluage soyl hath bred" (Spenser 1977, 742). Here Spenser himself suggests that a literary work is conditioned by the environment in which it has been produced. If this environment is remarkable-and Ireland was remarkably alien to any Englishman in the early modern period - then its presence will surely make itself felt.

This book will argue that Spenser's observations of the world around him-his geographical, political, and cultural environment-suffuse his allegory and that he expected the politically astute to read his poem with this in mind. Part of Spenser's milieu was undoubtedly his classical education and critics have rightly paralleled episodes and themes in The Faerie Queene with their ancient analogues. But Spenser brought his head full of classicism to one of the wildest areas directly under his monarch's jurisdiction, and we ought to attend to the ways in which his experiences shaped-consciously, and probably unconsciously too-his overtly classical epic. Moreover, we ought to read The Faerie Queene against other texts produced within the same cultural context. By attending to the writings of his fellow planters and to his experiences in Ireland we may better understand Spenser's relation to, and poetic transformation of, the "savage soil" of Ireland. 
Postcolonial thinking about Spenser and Ireland tends to privledge the nonclosure of colonial projects, the failure to resolve tensions, and especially the disruption of identity which colonialism entails. ${ }^{9}$ This book is by no means an attempt to provoke a debate using evidence for and against Spenser's hybridity and the fluidity of cultural boundaries because that would be an entirely different project. However, I would like to sound a word of caution: while we should be alert to ambivalences, blurred boundaries, and nuances in early modern English writings on Ireland by Spenser and his contemporaries these ambivalences should not blind us to the colonial agenda and the victories of the colonizers. Willy Maley has referred to "the genocidal actions of English forces" in Munster between 1580 and 1583. During these years approximately thirty thousand people living in the Munster area were eradicated in order to make way for around four thousand New English settlers. Maley comments: "The English euphemism for the settlement which followed in the wake of this act of genocide, 'repeopling', hardly begins to tell the story of that horrific depopulation" (Maley 1997, 61). In the light of the reality of such victories, the rhetoric of the "Supplication" should remind us that, despite our efforts to become ever more nuanced and sophisticated readers, some texts will not allow us to get very far.

\section{Chapter 2}

Religious Conflict: Truth, Error, and Duplicity

Traditional interpretations of Spenser's allegory, both moral and historical, have tended to identify Una as 'Truth', specifically the truth of the Reformed Church. Duessa, her opposite, has been identified as the whore who symbolizes Roman Catholicism, whilst Error has been interpreted as religious error, the enemy of the true word (heresy), or more generally as falsehood and $\sin ^{10}$ This chapter explores 
Spenser's demonization of the Catholic Irish in The Faerie Queene and the View. By no means do all the demons in The Faerie Queene represent Irish Catholics, but there is evidence of a particularly Irish Catholic dimension to Spenser's depiction of Duessa and Error.

In Book 1 of The Faerie Queene images of beauty are used by Spenser to endorse the status of Elizabeth 1 as head of the Protestant church and grotesque images are used to demonize the enemies of that church, and of Elizabeth. Spenser builds on the figure of Elizabeth as divine representative of Protestant reform to endorse his militant Protestant position throughout Book 1. In his delineation of the grotesque physical appearance of Una's enemies, Spenser illustrates the contemporary demonization of two groups: women and the colonized Irish (including Irish women), both constructed as the Other. Such demonization is explicit in the View and is a feature of other colonialist writings. Spenser depicts the evil which he believes threatens the English Protestant state as sexually and morally degenerate.

It is now generally accepted that in Book 1 of The Faerie Queene Spenser alludes to the New Testament Revelation of St. John. In his Observations on the Faerie Queen of Spenser (1762), Thomas Warton identified such allusions and dismissed them as impious $(1762,101)$. The Variorum edition of Spenser's works does not, however, include the Revelation amongst its list of the sources of Book 1 (Spenser 1932, xi-xii). Josephine Waters Bennett in The Evolution of The Faerie Queene (1942) was the first to suggest the primacy of this source for Book 1, both structurally and allegorically. She showed that the Revelation was interpreted in the Renaissance as a prophecy of Protestant Reformation and an allegory of conflict with the Roman Catholic church (Bennett 1942, 108-23). ${ }^{11}$ Such an interpretation is evident in the commentary of the 1560 edition of the Geneva Bible, which Spenser certainly would have known. This was the most popular English version of the Bible from 1576 until the outbreak of the Civil War in $1642 .^{12}$

Religious conflict provides the overall structure which organizes Book 1. Una is identified by Spenser as "Truth" (1.2.argument) and her function is to demonstrate the Neoplatonic ideal of womanhood. Her beauty is a manifestation of her moral and spiritual goodness but in the context of historical allegory she can also represent the figure of Elizabeth, the representative of Protestant truth. Her name suggests oneness; she stands for the one true religion and must defend it from the duplicity of the Roman Catholic church. Of course Queen Elizabeth as defender of the Protestant faith against the Papists is an obvious parallel. Her motto was Semper Eadem, a Latin phrase meaning 'Always the same', and a translation of an English motto 'Be always one' (Rosinger 1968,13$).{ }^{13}$ Una is also a common Irish name (Smith 1935, 917) and thus Elizabeth's authority in Ireland, or the lack of it, is brought into focus. Una represents the Protestant church and state which, by the agency of Elizabeth's representatives, must free Ireland from the grip of Roman Catholicism. Redcrosse represents Holiness but he also personifies England and as an allegory of Saint George, Book 1 is a reminder that Elizabeth is the divine representative of Protestant reform.

When Una first appears she is not named but is described with great attention to iconographical details: 
A louely Ladie rode him faire beside,

Vpon a lowly Asse more white than snow,

Yet she much whiter, but the same did hide

Vnder a vele, that wimpled was full low,

And ouer all a blacke stole she did throw,

As one that inly mournd: so was she sad,

And heauie sat vpon her palfrey slow;

Seemed in heart some hidden care she had,

And by her in a line a milke white lambe she lad.

$(1.1 .4 \cdot 1-9)^{14}$

She is strongly associated with whiteness, denoting virginity and purity, which is another link with Elizabeth, the 'Virgin Queen'. Una is dressed in white and black which were, as Roy Strong has shown, Elizabeth's personal colours, worn by her champions in the tiltyard and by dancers in court masques (Strong 1987, 21). Una is also the ideal Petrarchan lady_fair skinned with fair hair-and is a source of physical lightness and brightness throughout Book 1 . She is compared to the physical brightness of the sun: "The blazing brightness of her beauties beame, I And glorious light of her sunshyny face" (1.12.23.1-2) but is also a source of spiritual light: "Her angels face / As the great eye of heauen shyned bright, / And made a sunshine in the shadie place" (1.3.4.6-8). This similarly is a link with the Woman Clothed with the Sun in the Revelation: "And there appeared a great wonder in heauen: A woman clothed with the sunne, \& the moone was vnder her feete, and vpon her head a crowne of twelue starres." (12:1). As Helen Hackett notes, contemporary Protestant commentators identified Elizabeth with the Woman Clothed with the Sun and she cites Edward Hellwis who in A Maruell, Deciphered, his commentary on chapter 12 of the Revelation, indicates that he regards the Woman Clothed with the Sun to be both Elizabeth and the Church of England (Hackett 1995, 135-36; Hellwis 1589). The nationalistic identification can be taken further. In Spenser's depiction of Una there are connotations of purity which remains uncontaminated by the darker elements that attempt contamination throughout Book 1.

Una's association with the land of Eden, via her parents Adam and Eve, prefigures Irena as a personification of Ireland in Book 5. To a degree Una also is an idealized allegorical representation of Ireland. Critical discussion of Spenser's allusions to Ireland in The Faerie Queene usually focuses on Book 5 where Artegall, the knight of Justice, frees Irena from the grip of Grantorto, the giant who represents Catholic power. Irena is an anagram of Ierna which, according to William Camden, was the Classical name for Ireland (Camden 1971,963$).{ }^{15}$ It is also important to note that Irenius, the masculine form of Irena, is generally considered to be Spenser's spokesman in the View. ${ }^{16}$ If Una can be said to denote the actual land in some way then what occurs is a sexualizing and gendering of the colonized landscape. There is an emphasis on Una's white clothes, her white horse and lamb, and her pale skin. A pale complexion, which could give the impression of a green tinge, was often identified with green sickness, an anaemic disease commonly attributed to a virgin's sexual fantasies which manifested itself through an unhealthy pallor and could only be cured by a sexual encounter (Williams 1994, 621-24). In Luke Gernon's A Discourse of Ireland, Ireland itself is conceptualized as a young woman suffering from this ailment. Although later than The Faerie Queene, Gernon's gendered 
personification of the colonized land is illuminating for the connection it draws between the act of appropriating land and the construction of that land as young, female, pale, and very beautiful:

This Nymph of Ireland, is at all poynts like a yong wenche that hath the greene sicknes for want of occupying. She is very fayre of visage, and hath a smooth skinn of tender grasse. Indeed she is somewhat freckled (as the Irish are) some partes darker than other. Her flesh is of a softe and delicat mould of earthe, and her blew vaynes trayling through every part of her like ryvoletts. . . . Her bones are of polished marble, the grey marble, the blacke, the redd, and the speckled, so fayre for building that their houses shew like colledges, ... . Her breasts are round hillockes of milkyeelding grasse, and that so fertile, that they contend wth the vallyes. And betwixt her leggs (for Ireland is full of havens), she hath an open harbor, but not much frequented. . . . It is nowe since she was drawne out of the wombe of rebellion about sixteen yeares, by'rlady nineteen, and yet she wants a husband, she is not embraced, she is not hedged and diched, there is noo quicksett putt into her. (Falkiner 1904, 349-50)

Ireland's harbour being "not much frequented" suggests that it has been visited at least once before, by the Anglo Normans in the twelfth century. Yet the land is still not conquered and so, like a virgin, it has yet to be husbanded. The "yong wenche" suffering from green sickness needs the controlling influence of a husband, and Ireland is penetrated with a Protestant sword in an attempt by the English to impose control on it. Spenser identifies Una with the physical land of Ireland and at the same time, as a surrogate of Elizabeth, she is the rightful ruler of that land. The fusion of ruler and land to be ruled was made explicit in the naming of the colony of Virginia which identified the land with Elizabeth, the virgin queen, and simultaneously asserted her right to govern it. Elizabeth's motto Semper Eadem (always one) implies fusion in her royal body of the separate and typically gendered identities of land as female and monarch as male ruler of that land.

The woman-as-land trope is not peculiar to Ireland, being also evident in colonialist discourse of the New World. An important distinction between the colonial experience in Ireland and in the New World was that the latter was seen as virgo intacta. Whilst Ireland's harbour is said to be "not much frequented", the harbours of the New World had not been frequented at all. The land as a green-sick virgin ripe for penetration is evident in Raleigh's famous description of Guiana as "a Countrey that hath yet her Maydenhead" (Raleigh 1596, sig. N4v). Louis Montrose points out that Raleigh's metaphor of Guiana's maidenhead "activates the bawdy Elizabethan pun on countrey, thus inflaming the similitude of the land and a woman's body, of colonization and sexual mastery" (Montrose 1993, 188). In the late sixteenth century, allegorical personifications of America as a female nude appeared in paintings and engravings, and on maps and title pages of books throughout Western Europe (Montrose 1993, 179). Other examples of colonized land represented as a naked female can be found in Ripa's book of moral emblems, Iconologia, which depicts a female America and Africa as "almost naked" whilst significantly Europe, also personified as female, is richly clothed (Orgel 1976). ${ }^{17}$ Of course the process of colonization informed literary works. Donne's Elegy 19 "To his Mistress Going to Bed" uses the metaphor of exploration, of the ownership of land and the wealth of land, to articulate the sexual: 
Licence my roaving hands, and let them go,

Before, behind, between, above, below,

O my America! my new-found-land,

My Kingdom's safest, when with one man man'd.

My Myne of precious stones: My Emperie,

How am I blest in thus discovering thee?

(Donne 1669, 98)

A radical implication of the woman-as-land trope is evident in some twentieth-century literature exploring colonialism. In "Act of Union" Seamus Heaney depicts colonized Ireland as a victim of rape. Ireland is female and the voice of the poem is male and English, speaking of invasion in terms of sexual penetration (Heaney 1975, 49).

Una's land is terrorized by the dragon of Roman Catholicism and Redcrosse as the English St. George must free her from its influence. This is Protestant appropriation of the Irish Catholic myth of St. Patrick eradicating snakes from Ireland. In Redcrosse is conflated the roles of St. Patrick and St. George, both of whom cleansed the land of the serpent/dragon. For Spenser the land belongs to Elizabeth, idealized here as the beautiful pale young lady. The fiend Satan, that is the Roman Catholic church, is her enemy and is manifested in the actions of her rebellious Irish subjects supported by Catholic Europe.

By contrast with Una, who is associated with light, the figure of Error constitutes all that is dark and menacing. Error is both physically and morally repulsive and it takes the brightness of Redcrosse's Christian armour to illuminate her dark den:

By which he saw the vgly monster plaine, Halfe like a serpent horribly displaide, But th'other halfe did womans shape retaine, Most lothsom, filthie, foule, and full of vile disdaine.

(1.1.14.6-9)

Evidence for Error's gross sexual appetite can be found in her monstrous brood:

Of her there bred

A thousand yong ones, which she dayly fed, Sucking vpon her poisonous dugs, eachone Of sundry shapes, yet all ill fauored:

(1.1.15.4-7)

The depiction of Error and her young seems to be indicative of negative English attitudes toward Ireland and the Irish. Ann Rosalind Jones and Peter Stallybrass refer to the English writers Fynes Moryson and Barnaby Rich who saw snake-like slipperiness and deception in the attempts by the Irish to conceal themselves from the colonists. This concealment occurred on many levels: in the Irish landscape, through language, and through literal concealment of the body by way of the glib and the mantle (Jones \& Stallybrass 1992, 164-65). ${ }^{18}$ From Aesop came warnings that the serpent was "Evil for Good" and "Cursed Above all Cattle", and admonitions against "Cherishing a Viper" (Aesop 1964, 55, 56, 89). In Richard 2 Shakespeare invoked the association of the Irish foot-soldiers, or kerns, 
with serpents: "We must supplant those rough rugheaded kerne, / Which liue like venome, where no venome else, / But onely they haue priuiledge to liue" (Shakespeare 1597, D1r). ${ }^{19}$

In England's Eliza Richard Niccol identified Error's brood as Catholics who presented a threat to English national security: not the Irish but rather those Catholics sent to England by the Pope and Spain (Niccols 1610, Fff6v). Spenser's portrayal of Error and her brood betrays a dread of the progeny of the Other, and a fear that they will continue the fight against the true church.

The writings of some early modern English commentators on Ireland betray hostility directed specifically toward Irish women and childbirth with anxiety about their progeny demonstrated in an uneasiness about emissions from women's bodies. In the View Irenius says that the Irish language was learnt by the Old English, descendants of the Anglo-Normans, through the practice of fostering and intermarriage with the Native Irish. He uses the metaphor of the mother's milk to illustrate the infectious spread of the Irish language: "for firste the Childe that suckethe the milke of the nurse muste of necessitye learne his firste speache of her, the which beinge the firste that is envred to his tounge is ever after moste pleasinge vnto him" (Spenser 1949, 119). The danger is situated in the foster mother's breast and she transmits not only her language but also her seditious nature to the child: "they moreouer drawe into themselues togeather with theire sucke even the nature and disposicion of theire nurses" (ibid.). William Camden similarly disapproves of the Irish custom of fostering and attacks the supposed sexual promiscuity of Irish nurses who "think it worth whoring at any time, to have suckling of an infant" and will influence the sexual behaviour of the children by "bring[ing] them up to all manner of lewdness". He suggests that the custom of nursing disrupts natural familial bonds because foster children who have sucked from the same breast have a greater sense of loyalty to each other than those who are biologically related (Camden 1971, 1044). Camden locates all blame for the supposed moral degeneration in Ireland on the custom of fostering and the actions of Irish nurses: "the corruption and debauchery of Ireland are, tis believed, to be imputed to no other cause than this method of nursing" (Camden 1971, 1044). In A New Description of Ireland Barnaby Rich refers to Irish childbirth with disgust: "I will not speak of those affairs belonging to childbearing women, that are no less uncivil than uncleanly in many their demeanors belonging to those businesses" (Rich 1610, E4v). Fynes Moryson, secretary to Lord Deputy Mountjoy, comments on the unnatural ease of Irish childbirth:

Some say that commonly the women have little or no pain in child-bearing . . . they have such easy deliverance, and commonly such strange ability of body presently after it, as I have never heard any woman in the world to have the like . . . (Falkiner 1904, 318) $^{20}$

Error bears the tail of a serpent but "th'other halfe did womans shape retaine" (1.1.14.8), so presumably she has the breasts, face, and hair of a woman. The serpent that tempted Eve was often represented with the face, and sometimes the upper body, of a woman. Roland Mushat Frye shows that the image of the hybrid female-serpent can be traced back to the late twelfth century where "we encounter for the first time what was to become an immensely popular and 
persistent representation - the combination of a serpent's body with a woman's head or torso" (Frye 1978, [103]). ${ }^{21}$ The presence of a hybrid female-serpent in The Faerie Queene points to a tradition of associating beautiful women with evil and identifying the evil which may lurk within beauty through that part of the creature's body which is not human. ${ }^{22}$ This makes for easy identification of Error's degenerate nature, which is more difficult in the case of Duessa because the signs of her degeneracy are not easily read.

The appearance of Error is similar to that of Echidna in Book 6 who possesses the face and front of a beautiful young woman:

Echidna is a Monster direfull dred,

Whom Gods doe hate, and heauens abhor to see;

So hideous is her shape, so huge her hed, That euen the hellish fiends affrighted bee At sight thereof, and from her presence flee: Yet did her face and former parts professe A faire young Mayden, full of comely glee; But all her hinder parts did plaine expresse A monster Dragon, full of fearefull vglinesse. (6.6.10.1-9)

It is her "hinder parts", the anal/genital area, that arouse the most disgust. Similarly the monster parented by Typhaon and Echidna that accompanies Geryoneo in Book 5 is described in a way that anticipates the description of its mother:

A huge great Beast it was, when it in length

Was stretched forth, that nigh fild all the place,

And seem'd to be of infinite great strength;

Horrible, hideous, and of hellish race,

Born of the brooding of Echidna base,

Or other like infernal furies kinde:

For of a Mayde she had the outward face,

To hide the horrour, which did lurke behinde,

The better to beguile, whom she so fond did finde.

(5.11.23.1-9)

Again, the face of a young woman is used to hide sin, recalling Duessa, and the beast is serpent-like, recalling Error. As with Error there is a dread of the progeny of the Other, the fear that a vile monster is generating children who will continue the fight against the true church. The monster is "of hellish race" (5.11.23.4), evoking similar claims about the native Irish such as those in the View where Irenius attempts to prove lineage between the Irish and the Scythians (Spenser 1949, 82-97). Richard McCabe has referred to Spenser's efforts to stigmatize the culture of the Irish through "a pseudo-anthropological investigation into its barbarous 'Scythian' origins", ignoring their common Briton antecedents (McCabe 1993, 100).

The notion of Irish savagery is further emphasized in the actions of Error's children who feed from the blood of their dying mother. This corresponds to Pliny's description of the end of the viper's gestation: 
After two days she hatches the young inside her uterus, and then bears them at the rate of one a day, to the number of about twenty; the consequence is that the remaining ones get so tired of the delay that they burst open their mother's sides, so committing matricide. (Pliny 1940, 10.82.171-176)

Stories of the savage Irish nature with its supposed history of cannibalism or near cannibalism and love of blood, are evident in the writings of English commentators on Ireland. Concerning the ancestors of the Native Irish, Edmunde Campion in $A$ History of Ireland (1571) relates that

Strabo, the famous geographer, who florished under Augustus and Tiberius Caesar more than fifteen hundred yeares agoe, tellethe (without asseveration) that the Irishe weare great gluttons, eaters of mans fleshe, and counted yt honourable for the parentes deceased to be eaten up of theire children, and that in open sight theye medled with theire wyves, mothers and doughters, which is the less incredible considering what St. Hierom avouchethe of the Scotes, theire ofspring and alies, and what all histories doe witnes of the Scithians, theire auncient founders. (Campion 1963, [21], f. 18v) ${ }^{23}$

Writing on Ireland in Holinshed's Chronicles, John Hooker reported that after the defeat of the Papal force in 1580 the people of the area surrounding Smerwick ate the bodies of dead men washed up on shore from a shipwreck, so severe was the extent of the famine after the Desmond rebellion (Holinshed 1587, Rjv-Rijr). The extenuating circumstances of the famine become obscured by the fulfilment of what the English suspected all along, that the Irish are savages. In the View Irenius refers to a scene he has witnessed which endorses this opinion:

... at the execucion of A notable Traitour at Limericke Called murrogh Obrien I sawe an olde woman which was his foster mother take vp his heade whilste he was quartered and sucked vp all the blodd rvnninge theareout Sayinge that the earthe was not worthie to drink it and thearewith allso steped her face, and breste and torne heare Cryinge and shrikinge out moste terrible/ (Spenser 1949, 112)

O'Brien was executed in 1577 so Spenser was probably in Ireland at this time and therefore able to witness the execution, or at least hear about it. There is a marked similarity between the execution in Limerick and the action of Error's brood:

Her scattred brood, soone as their parent deare

They saw so rudely falling to the ground, Groning full deadly, all with troublous feare, Gathred themselues about her body round, Weening their wonted entrance to haue found At her wide mouth : but being there withstood They flocked all about her bleeding wound, And sucked vp their dying mothers blood, Making her death their life, and eke her hurt their good. (1.1.25.1-9) 
It may be that Spenser recalled what he witnessed at O'Brien's execution when he came to write about Error and her brood. In both passages blood is consumed after decapitation.

In Renaissance iconography familial consumption of blood recurs in the figure of the pelican which was reputed to pierce her breast in order to feed her young. In an emblem by George Wither an explicit connection is made between the pelican and Christ to show that he shed blood to provide spiritual sustenance for humankind (Wither 1975, 3.XX.Y2v). Roy Strong claims that the pelican was used as a symbol of Elizabeth's relationship to her people. In the famous 'Pelican' portrait by Nicholas Hilliard (which is, Strong claims, the earliest evidence we have of her use of that emblem), a pelican is suspended from a jewelled necklace worn by the Queen (Strong 1987, 79-83). The symbol of the pelican thus appeared in both religious and political contexts, functioning as a figure of spiritual nourishment.

We might well ask why it is that the consumption of blood depicted as repugnant in the Error episode is utilized as a metaphor in praise of Elizabeth. Shakespeare's use of the pelican is an interesting and representative example of the way in which the pelican functioned as a symbol. He refers to the pelican in three plays: King Lear, Richard 2, and Hamlet. It is mentioned only once in each play. In King Lear Goneril and Regan are represented as unnatural offspring by Lear: "Is it the fashion that discarded fathers, / Should haue thus little mercy on their flesh, / ludicious punishment twas this flesh, / Begot those Pelicane daughters" (Shakespeare 1608, G2r; 3.4.68-71). In Richard 2 John of Gaunt positions the pelican as an unnatural and cannibalistic glutton and, railing on Richard, declares: "Oh spare me not my brothers Edwards sonne, / For that I was his father Edwards sonne, / That bloud already like the Pellican, / Hast thou tapt out and drunkenly carowst"

(Shakespeare 1597, C4v-D1r; 2.1. 125-28). Later, in a possible reference to the pelican, Bolingbroke, having received news that his order to kill Richard has been carried out, expresses his regret that he should receive sustenance from blood and so benefit from murder: "Lordes, I protest my soule is full of wo, / That bloud should sprincle me to make me grow" (Shakespeare 1597, K2r; 5.6.45-46). Only in Hamlet is the pelican depicted in a positive light. Laertes, having learnt about the death of Polonius from Claudius, affirms that he will have revenge only on his father's enemies, not his friends: "To his good friends thus wide l'le ope my armes, I And like the kind life-rendring Pelican, / Repast them with my blood" (Shakespeare 1604, L1v; 4.5.145-47). The above examples from Shakespeare suggest that while the adult pelican was always represented as altruistic, her young were often portrayed as gluttonous. This is also evident in two Latin emblems by Andreas Alciatus (91 and 96) in which the pelican is associated with a full belly so as to illustrate gluttony (Daly, Callahan \& Cuttler 1985). Spenser's disgust is directed toward Error's young who greedily suck, and significantly they suck upon the blood of their dying mother so the emphasis is not on the generosity of the parent but on the gluttony and cannibalism of her offspring.

Some contemporary English accounts of Irish cannibalism describe a people not naturally disposed to anthropophagy but reduced to such actions through the brutality of war. In the View Irenius describes the starving Irish in Munster as "Anotomies of deathe" that "did eate the dead Carrions, happie wheare they Coulde finde them, Yea and one another sone after, in so muche as the verye carkasses 
they spared not to scrape out of theire graves" (Spenser 1949, 158). Such accounts-although they explain the act of cannibalism as a response to an exceptional occurence rather than an everyday event-nevertheless contribute to English perceptions of Irish Catholics as capable of savagery. Often the associations drawn between the Irish and cannibalism are by reference to the act as a metaphor for barbarism. Yet sometimes it can be difficult to distinguish metaphor from report, for example in A Discoverie of the True Causes Why Ireland was Never Entirely Subdued John Davies says of the Irish: "they were little better then Canniballes, who doe hunt one another; and hee that hath most strength and swiftnes, doth eate and deuoure all his fellowes" (Davies 1612, Y2v-Y3r). Accounts of natives indulging in cannibalistic orgies were also reported by those returning from expeditions to the New World, but specific reference to Irish cannibalism may also be a veiled allusion to the Eucharist and the Catholic belief in transubstantiation.

Error's den is situated in the Wandring Wood but it is more than just a geographical location. The word "error" derives from the Latin errare, "to wander", and points to the dangers of straying from the path of truth. For Spenser the woods represent danger and the hero's virtue is tested in such an environment. Richard McCabe draws a parallel between Redcrosse's entry into the wood of Error and Spenser's first experience of the Irish campaign: Lord Grey's defeat in the woods of Glenmalure by the O'Byrnes and O'Tooles, whose names Spenser believed signified 'woddye' and 'hillye' (McCabe 1993, 83). Whilst the English landscape familiar to Spenser was undergoing extensive deforestation, Ireland was still covered by a considerable amount of woodland which provided shelter for Irish rebels and wild animals and presented a great obstacle to the colonizers (Quinn \& Nicholls 1976, 36). As we shall see in chapter 5 , colonisation brought enormous changes to the Irish countryside and the destruction of woodland not only made the interior more accessible but acted as an inducement to potential settlers.

When Una is led into a forest and almost raped by a pagan knight she is rescued by the creatures who inhabit the woodland to which she has been brought. The Saluage Nation are described as "A rude, misshapen, monstrous rablement" (1.6.8.7) and it is their gruesome appearance that scares away the would-be rapist. Their reaction to Una is the same as all other reactions to her throughout Book 1: "All stand astonied at her beautie bright, / In their rude eyes vnworthie of so wofull plight" (1.6.9.8-9). Her beauty has the power to transfix her observers and because of it she is worshipped by the Saluage Nation: "The woodborne people fall before her flat, I And worship her as Goddesse of the wood" (1.6.16.1-2). This seems to be an allusion to the Roman Catholic practice of venerating icons. Una must teach the ignorant woodland folk that their worship of her is profane: "her gentle wit she plyes, I To teach them truth, which worshipt her in vaine, I And made her th'Image of Idolatryes" (1.6.19.5-7). The creatures are ignorant and worship with "feeble" eyes which indicates that they do not understand the truth she represents. Correction takes time: "But when their bootlesse zeale she did restraine / From her own worship, they her Asse would worship fayn." (1.6.19.8-9). Spenser creates a fantasy of truth, the English Protestant church and state, being welcomed by friendly savages who are ignorant of the correct means of worship. They are unable to recognize the truth of Protestantism, but are nevertheless eager to listen and willing to learn. Una's encounter with this Saluage Nation locates her as the learned teacher 
Fitzpatrick, Joan. 2000b. Irish Demons: English Writings on Ireland, the Irish and Gender By Spenser and His Contemporaries. Lanham. University Press of America.

among the savages. An alien in this environment, she is accepted nonetheless as their educator.

The demonization of Irish Catholics evident in Spenser's presentation of Error and her brood is also apparent in his construction of Duessa as one of Una's most dangerous enemies. In his analysis of the relationship between Una and Duessa, Frank Kermode explains that Una represents Elizabeth as the head of a church which claimed to inherit the powers of the primitive Eastern church of the Constantinian Empire. Una is the daughter of a king whereas Duessa's false description of her father as an emperor "alludes to papal usurpations on the imperial power, a constant source of Protestant complaint". Spenser presents Duessa as "a representative of a religion not only anti-Christian but also anti-imperialist, antiuniversalist. Duessa's very name accuses her of schism" (Kermode 1971, 42-43). Via Duessa, Spenser manipulates the strength of feeling against victims (mostly women) of witch-hunts throughout Europe and, by associating her with Catholicism, exploits anti-Catholic feeling in sixteenth-century England. Duessa is more dangerous than Error because it is more difficult to penetrate the mask of beauty within which she hides a rotten interior. When Duessa first appears she is in the company of a "faithlesse Sarazin" (1.2.12.6) and in this way Catholicism is associated with the infidel. This is further evidence of the Christian/pagan dichotomy noted by McCabe $(1989 a, 112)$ that exists throughout the poem whereby Roman Catholics are figured as pagans and the Reformed Church is the only true Christian religion. The description of Duessa is a close parallel to that of the Whore of Babylon:

He had a faire companion of his way, A goodly Lady clad in scarlot red, Purfled with gold and pearle of rich assay,

And like a Persian mitre on her hed She wore, with crownes and owches garnished, The which her lauish louers to her gaue; Her wanton palfrey all was ouerspred With tinsell trappings, wouen like a waue, Whose bridle rung with golden bels and bosses braue. (1.2.13.1-9)

The Revelation describes the Whore of Babylon as: "araied in purple \& skarlat, \& guilded with golde, \& precious stones, and pearles, [with] a cup of golde in her hand, ful of abominations, and filthines of her fornication" (17.4). The allusion to Duessa as the Whore of Babylon is further extended when Duessa becomes the mistress of Orgoglio (1.7.16-18). The Geneva Bible commentary represents the Catholic/Protestant religious debate in terms of gender: "Antichrist is cõpared to an harlot because he seduceth $y^{\mathrm{e}}$ worlde with vaine wordes, doctrines of lies, \& outwarde appearace", and explains that "This woman is the Antichrist, that is, the Pope with $\mathrm{y}^{\mathrm{e}}$ whole bodie of his filthie creatures . . . whose beautie onely standeth in outwarde pompe \& impudencie and craft like a strumpet" (Anon. 1560, GGg4r notes $b$ and $f)$.

The Pope as head of the Catholic church, a position which is strictly male, is figured as a whore, an epithet which is strictly applied to the female. D. Douglas 
Waters has pointed to a widespread tendency in the Protestant religious writings of Elizabethan England to use witchcraft and the figure of the whore as a generalized metaphor for Roman Catholic seduction. He gives as an example Henry Bullinger's A Hundred Sermons vpon the Apocalipse (trans 1561) in which Bullinger states that by the "inchauntmentes" of Rome, "all nations have been seduced"; similarly Augustine Marlorat in A Catholike Exposition upon the Reuelation of Sainct John (trans. 1574.) refers to Rome as the scarlet whore or Antichrist and her "sorcerie, which betokeneth hir superstitous religion, hir whorish doctrine, and hir miracles wrought by diuelish practices . .." (Waters 1966, 281-82). ${ }^{24}$ Although Alan MacFarlane claims that "there is no convincing evidence that witchcraft prosecutions were linked to an attack on Roman Catholics" he concedes a correlation between witches, witchcraft, and Catholicism, acknowledging that "papists were sometimes generally termed 'witches' and even reading the psalms was termed conjuration . . ." (MacFarlane 1970, 188). MacFarlane thus acknowledges that witchcraft and Catholicism were connected "in a general way" (MacFarlane 1970, 190n14). Diane Purkiss also notes that opponents of Catholicism tended to conflate it with witchcraft:

It was common to decry popery and mass as witchcraft, or simply to fail to make distinctions between them. For the godly, papists were witches; indeed, anyone ungodly who practised traditional ritual might be viewed as trafficking with Satan. (Purkiss 1996, 154)

Duessa is physically beautiful and, like the Roman Catholic Church with its use of pageant and spectacle, she is visually seductive. According to its critics, the outward appearance of Roman Catholicism hid an inherent moral degeneracy. The identification of Duessa with Roman Catholicism was made by James 6 of Scotland who read Book 5 as an indirect attack on himself via his mother, Mary Queen of Scots, and called for the arrest and punishment of the poet. Spenser went unpunished but the distribution of the second part of The Faerie Queene was banned in Scotland (McCabe 1987, 224). McCabe believes that this was a sensitive issue for James during the succession problem and notes that once established on the English throne James did nothing to prevent the publication of the 1609 folio edition of The Faerie Queene (McCabe 1987, 224).

Duessa is the opposite of Una whose outward beauty is a manifestation of inner goodness. As a witch she is an agent of the devil and, as A. C. Hamilton notes, her name suggests that she is two-faced, a "Double Being" whose beauty masks a rotten interior (Spenser 1977, 52). Roland M. Smith makes a convincing case for 'Duessa' being an English corruption of an Irish name, a compound of Dub, 'black' and Ésa, a woman's name which features in Irish legends and was associated with vice (Smith $1935,918)$. Duessa's promise of moral integrity is only "seeming" (1.2.37.2), that is, she presents a false appearance and because her appearance is a lie she is an enemy of truth. When Duessa first meets Redcrosse she does not reveal her true self but rather lies about her name. She calls herself Fidessa, which is ironic because, according to Hamilton, it denotes 'being faith' from the Latin fides (faith) and esse (being) (Spenser 1977, 50). Her nominal faithfulness, like her beauty, is a pretence and she carefully manipulates outward signs of virtue in order to deceive Redcrosse. 
Duessa's true nature is revealed in the inset story of Fradubio and his lady Fraelissa. Fradubio exhibits moral weakness when he begins to compare the physical appearance of Duessa with that of his own lady:

So doubly lou'd of Ladies vnlike faire, Th'one seeming such, the other such indeede, One day in doubt I cast for to compare, Whether in beauties glorie did exceede;

A Rosy girlond was the victors meede:

Both seemde to win, and both seemde won to bee,

So hard the discord was to be agreede.

Fraelissa was as faire, as faire mote bee,

And euer false Duessa seemde as faire as shee.

$(1.2 .37 .1-9)$

In this beauty contest Fradubio betrays his arrogance and thus his vulnerability to the guile of Duessa. Both Redcrosse and Fradubio judge by appearances only, which stimulates their lust thus making them weak and morally confused. By abandoning Una in the mistaken belief that she is wanton and becoming Duessa's companion, Redcrosse rejects truth in favour of falsehood and this is mirrored in Fradubio's desertion of the morally upright Fraelissa. It may be that this is an allegory of the English experience in Ireland. The Old English, descendants of the Anglo-Normans who settled in Ireland in the twelfth century, were often accused by the New English of 'going native', of being seduced and contaminated by Native Irish culture. This was viewed by the New English in Ireland as a betrayal of their supposedly superior English nature. In the View Irenius says that "the moste parte of them are degenerated and growen allmoste meare Irishe yea and more malitious to the Englishe then the verye Irishe themselves" (Spenser 1949, 96). When Duessa's rotten interior is imaginatively cast onto the exterior of the truly beautiful Fraelissa her 'forged beauty' (1.2.36.1) usurps Fraelissa's natural, and therefore God-given, beauty which identifies her as a surrogate for Una, the symbol of English Protestant truth.

Duessa constantly changes sexual partners and this sexual promiscuity is not only indicative of her fallen moral nature and lack of spiritual faithfulness, but also suggests venereal disease. Her evil is contagious, spreading its influence amongst the wholesome and corrupting the good. The figure of the whorish witch as a generalized metaphor for Roman Catholic seduction is again brought into play as a threat to good Christians like Redcrosse and Fradubio. As Alan McFarlane points out, envy and lust were both associated with the witch in Tudor and Stuart England (MacFarlane 1970, 215). These vices are evident in Duessa's contrary physical states: lust in the beautiful form she adopts so as to lure her victims and envy when she appears as she really is, and as a typical witch, old and ugly. Fradubio describes Duessa in her true shape:

Her neather partes misshapen, monstruous, Were hidd in water, that I could not see, But they did seeme more foule and hideous, Then womans shape man would beleeue to bee. 
She is "a filthy foule old woman" ((1.2.40.8), a "diuelish hag" (1.2.42.1), and her voluntary stripping here anticipates the humiliation of her public stripping later which draws upon the stripping of the Whore of Babylon in the Revelation (17.16). Fradubio's revulsion is centred on Duessa's anal/genital area and so his disgust toward the old woman is one of sexual loathing. Significantly, 'devil marks' were often found on a witch's breasts or genital area (Robbins 1959, 135-37). The old woman is the antithesis of the idealized young woman and just as youth is a necessary corollary to beauty so a lack of youth implies ugliness.

Spenser presents Una as an idealized surrogate of Elizabeth as 'Truth', the head of the English Protestant Church and people. Yet Una is also an idealized allegorical representation of Ireland which allows Spenser to show both the colonizer and the colonized landscape itself endorsing the subjugation of the Irish. The depiction of Error and her young constructs the Irish as snake-like and reveals a dread of the savage progeny of the Other. Similarly Duessa as the enemy of truth and the whorish witch represents the threat of contamination and seduction by Roman Catholicism of good Protestant knights.

In Book 1 of The Faerie Queene Spenser demonstrates an aesthetic of beauty and/or grotesqueness which reveals an anxiety about the Other. This anxiety is manifested in images of threatening and unpredictable female sexuality and it provokes attempts at containment within images of the Neoplatonic ideal. In Spenser's allegory ugly female forms represent the malevolent whilst beautiful women represent either spiritual and moral goodness or else spiritual and moral depravity. Female beauty cannot of itself be trusted for it is potentially deceptive and only the faithful can read the signs. If women cannot be trusted, English colonial writings seem to say, neither can the Irish. Spenser's anxiety about the potentially deceptive nature of female beauty, an anxiety concerning female sexual power, is related to anxieties about the power of the Irish Catholic enemy. By drawing parallels between Spenser's poem and other writings from this period we may raise questions concerning contemporary attitudes toward demonized groups, the Irish and women, and the role of the beauty metaphor in a work that is both imaginative and political.

\section{Chapter 3}


Acrasia, Ruddymane, and the Red Hand of Ulster

In Poetic Freedom and Poetic Truth Harriet Hawkins considers Guyon's violence in the Bower of Bliss (2.12.83) and asks a crucial question: "Why does Guyon go so far? The source of all the danger in the garden, the sorceress Acrasia, has already been captured" (Hawkins 1976, 72). Perhaps the answer to this question, which has long been asked by critics, lies in the narrator's justification for Guyon's violence in the Bower of Bliss, expounded at the beginning of the book in the Ruddymane episode and overlooked by critics such as Hawkins. ${ }^{25}$ In the Ruddymane episode (2.1.35-61) the strong visual and emotional impact of a child's hands soaked in his mother's blood is used by Spenser to justify the violence perpetrated by Guyon in the Bower of Bliss. In his eighteenth-century edition of The Faerie Queene, John Upton twice remarks that the red hands of the babe allude to the emblem of the powerful Gaelic family of O'Neill (Upton 1987a, 378, 397). This chapter will enlarge upon Upton's suggestion and consider Ruddymane within the context of the political struggle in Ireland.

In his comments on the Ruddymane episode Upton cites the View where Spenser, in his inventory of Irish customs supposedly inherited from the Scythians, refers to Irish war-cries: ". . . at theire ioyninge of Battell they likewise Call vppon theire Captaines name or the worde of his Auncestours As they vnder Oneale crye Landargabo, that is the bloddie hande which is Oneles badge" (Spenser 1949, 103). Although Upton is right to make this connection with the Red Hand of Ulster his interpretation of the episode is unconvincing:

This wicked witch had slain the parents of young Ruddymane, the bloody-handed babe: - plainly alluding, I think, to the rebellion of the Oneals, whose badge was the bloody-hand, and who had all drank so deep of the charm and venom of Acrasia that their blood was infected with secret filth. [emphasis as original] (Upton 1987a, 378)

Given that the episode is about the seduction of "The gentlest knight . . . the good Sir Mordant" (2.1.49.8-9) it is strange that Upton should think it is the Native Irish O'Neills who have been infected. If Upton's reading of the allegory is correct then we might ask what group or individual Acrasia is meant to represent and who or what has infected the blood of the O'Neills.

The figure of Acrasia was undoubtedly influenced by Spenser's reading of classical myth and Italian Romances. Like Duessa, she is a descendant of Homer's Circe (The Odyssey), Ariosto's Alcina (Orlando Furioso), and Tasso's Armida (Gerusalemme Liberata). However, as well as the influence of ancient myth and Romantic epic there are also strong parallels between Spenser's whorish witches and contemporary depictions of Roman Catholics. As we saw in the previous chapter some Protestant religious writings of the early modern period used witchcraft and the figure of the whore as a metaphor for Roman Catholic seduction with the Mass itself being personified as a witch and whore. Due to the prominence of her role in the Ruddymane story it seems likely that the figure of Acrasia similarly 
alludes to Irish Catholicism. In Ireland political rebellion by its Catholic inhabitants was repeatedly described in terms of licentious behaviour. There was a real fear that virtuous New English men would be seduced and made degenerate by the Catholic Mass just as their Old English counterparts had been by Irish culture. Like Duessa, Acrasia is a fusion of the figure of the whorish witch and the Irish Catholic rebel. Anxieties about the political, religious, ethnic, and sexual alien are projected onto Acrasia and she becomes a justification for Guyon's violence in the Bower of Bliss. His actions imply approval of the violence of the New English colonists in Ireland and prefigure the violence of Artegall and Talus in Book 5.

The O'Neills, a Native Irish family, cannot be said to have been seduced by Irish culture, rather it was the Old English who had embraced Native Irish customs, including the Irish language. It is therefore probable that Mortdant, like Fradubio in Book 1, represents the Old English seduced, or infected, by a witch who is a representative of the Native Irish. The degeneration of the Old English is explained in sexual terms in the View. Irenius states that the Old English "are now muche more Lawles and Licentious then the verie wilde Irishe" and have become degenerate "thoroughe licentious Conuersinge with the Irishe or marryinge and fosteringe with them or lacke of mete nourture" (Spenser 1949, 113, 117). The politically subversive is figured as sexual with the word "licentious" carrying connotations of sedition as well as sexual promiscuity. Richard McCabe points out that Lord Grey referred to the Irish as sensual and licentious and John Derricke warned colonialists to avoid bewitchment by Celtic women (McCabe 1993, 86). ${ }^{26}$

The OED records frequent use in the sixteenth century of the adjective 'red hand', meaning 'red-handed' ("In the very act of crime, having the evidences of guilt still upon the person" OED red-handed a. 1). This legal term is pertinent to the Ruddymane story where the guilt of Acrasia has been projected onto the hands of the child Ruddymane. His bloody hands may also signify the wider violence of the colonial struggle in Ireland by evoking the resistance of the Gaelic O'Neills of Ulster and other Native Irish clans. Richard McCabe notes that Guyon's inability to clean blood from Ruddymane's hand recalls the description of Irish baptismal rites in Holinshed's Chronicles: "In some corner of the land they vsed a damnable superstition, leauyng the right armes of their infantes vnchristened (as they terme it) to the intent it might giue a more vngratious \& deadlie blowe" (McCabe 1993, 85; Holinshed [1577], D4v). A link between bloody hands and Irish aggression is also made by the author of the "Supplication" who claims that even those Irish in the pay of Elizabeth, if angered, "will threaten presently the bathinge of their bloody handes in the bloode of $o^{\text {re }}$ hartes" (Anon. 1995, 57).

In the View Irenius identifies the bloody hand as "Oneles badge" (Spenser 1949, 103) but Art J. Hughes notes that just before 1690 there was "an internal Gaelic controversy as to which clan could most strongly lay claim to the heraldic emblem of the Red Hand" (Hughes 1988, 85). Central to this dispute were the Gaelic poets. There are four extant poems from the dispute of the Red Hand which claim the emblem variously for different clans. Ownership of the emblem was contested by poets representing the Magennis clan of Iveagh, O'Neill of Tyrone, and Mac Dhomhnaill of the isles of Scotland (Hughes 1988, 83-86). That this emblem was the cause of dispute approximately one hundred years after it was mentioned in the 
View and alluded to in The Faerie Queene is evidence of its cultural and political potency. That competing clans took pride in the emblem indicates its force as a disconcerting symbol for the New English attempting to eradicate Gaelic power.

If we allow that Mortdant represents the Old English and his seductress Acrasia the Native Irish then we need to consider perceived links between Irish Catholics and the figure of the witch. Spenser follows the Continental conception of the witch as religious, political, and cultural alien: she is 'foreign', and because her foreigness is that of Catholic Europe she connotes the papacy. In the late Middle Ages it was thought that a witch got her powers via a pact with the devil. The European concept of witchcraft as devil-worship supposedly involved a verbal or written contract with Satan, signed with the blood of the executor (Summers 1926, 65-70). It was primarily the Roman Catholic church that introduced this concept of witches as followers of Satan and it was recognised as a central part of witchcraft only in mainland Europe. As Keith Thomas points out, this belief meant that witchcraft had become primarily a Christian heresy and the social malevolence of the witch was a secondary concern. The reverse was true in England where witchcraft continued to be prosecuted primarily as an anti-social activity rather than a heresy (Thomas 1971, 436-38). ${ }^{27}$ The English witch was usually suspected of frustrating everyday domestic tasks, and causing injury to, or killing, farm animals or people (Thomas 1971, 436-37). Her continental counterpart however, given her close relationship with the devil, was more sinister. It would appear that for Spenser this diabolical connection and her foreignness, associated with papacy, made the continental witch a more malevolent figure than her English sister. In The Faerie Queene Duessa and Acrasia are guilty of crimes which Thomas claims were "comparatively rare" in England but common on the mainland of Europe, that is, "interfering with the weather" 28 and "frustrating sexual relations between human beings" (Thomas 1971, 437). Spenser's witches are responsible for raising mists to defeat their opponents $(1.2 .38 .5,2.12 .34 .5)$ and coming between good knights and their ladies. Acrasia frustrates the chaste love between Amavia and Mortdant just as Duessa had that of Una and Redcrosse and that of Fradubio and Fraelissa.

In Book 2 of The Faerie Queene Ruddymane is a symbol of the harm done by witches to children. On the Continent accusations of cannibalism levelled at witches reveal anxieties about unnatural women preying on, rather than nurturing, the young. In his Compendium Maleficarum (Milan 1608) Francesco Maria Guazzo cites an extract from Sebastien Michaëlis's Pneumalogie (Paris 1587) which refers to the supposed crimes of a group of witches listed in a sentence passed at Avignon in 1582. Amongst their alleged victims were children:

many of them with your own knowledge and consent, you did with those magic spells suffocate, pierce, and kill . . . and cut off their heads, hands, and feet, and did cook and stew their trunks, and sometimes roast them, and at the bidding of your aforesaid evil Father [Satan] did eat and damnably devour them. (Guazzo 1970, 136)

Guazzo provides other reports of witches indulging in cannibalism: in Berne and Lausanne witches allegedly killed and ate their own children and in Berlin they supposedly cooked the child of a neigbour, presumably planning to eat it later had the mother not interrupted them (Guazzo 1970, 91). The association between witchcraft and cannibalism appears to have been a particularly Continental 
phenomenon. C L'Estrange Ewen points out that there are no accusations of the use of human flesh in English records until the time of James 1 and even then it was supposedly bones that were sought rather than flesh (Ewen 1933, 77). ${ }^{29}$ Like their continental counterparts, Irish witch-figures were also accused of cannibalism. In his Itinerary Fynes Moryson reports:

Captaine Treuor \& many honest Gentlemen lying in the Newry can witnes, that some old women of those parts, vsed to make a fier in the fields, \& diuers little children driuing out the cattel in the cold mornings, and comming thither to warme them, were by them surprised, killed and eaten, which at last was discouered by a great girle breaking from them by strength of her body, and Captaine Treuor sending out souldiers to know the truth, they found the childrens skulles and bones, and apprehended the old women, who were executed for the fact. (Moryson 1617, Bbb2r)

For Spenser, the behaviour of foreign witches who are religiously, politically and ethnically alien, is worse than that of English witches; the English witch is vile but, because English, she is restrained. The sacrifice of children was also attributed to Muslims. In "How the West Saw Medieval Islam" Malcolm Barber reprints a scene from Duc de Berry's fifteenth-century Livre des Merveilles du Monde to support his claim that "Child sacrifice was one of a variety of sordid pursuits attributed to idolatrous Eastern worshippers and luridly visualised in Western depictions throughout the Middle Ages" (Barber 1997, 46). We should remember that in The Faerie Queene and in the View Catholicism is often associated with unbelievers.

In early modern English culture there was a clear association between demonic Catholic figures and the shedding of Protestant blood. In chapter 17 verse 6 of the New Testament Revelation of St John the Whore of Babylon is described as being "drunken with the blood of Saintes, \& with the blood of the Martyrs of lesus", and was interpreted by some Protestant commentators, such as those who annotated the 1560 Geneva Bible, as the Antichrist, that is, the Pope (Anon. 1560, GGg4r). In Book 1 Duessa appears as the whore of Bablyon riding Orgoglio's "manyheaded beast", although in Spenser's text it is the creature rather than the whore that is described as being "bloudie mouthed with late cruell feast" (1.8.6.5). The association of the papist whorish witch with menstrual blood in particular is evident in Ben Jonson's The Alchemist where the puritan Tribulation Wholesome refers to "the menstruous cloth, and rag of Rome" (3.1.33). The editor of the Revels edition of the play, F. H. Mares points out that

The surplice was the rag of rome to puritans, satirically compared to a female garment, and as Rome is the 'Scarlet Woman' of Revelation, xvii, 'drunken with the blood of the saints and with the blood of the martyrs', the cloth stained with menstrual discharge becomes an apt—if revolting—metonomy. (Jonson 1967, 95n33)

An association between the Catholic enemy and menstrual blood is also evident in Thomas Gainsford's chapter describing Ireland in The Glory of England. He asserts that when the Irish have disputes amongst themselves and English officials attempt intervention they turn their complaints upon the English: 
then haue they stood on their guard and taken indirect occasions to condemne our vsurpation, whereby their odious and hatefull repinings, like a menstrous cloth, have made their disobedience loathsome and brought upon them such miseries as a calamitous warre and angry Prince inflicteth turbulent people withall. (Gainsford 1618, L3r)

Once again, Political rebellion is figured in gendered terms and described as something these male writers find entirely disgusting: the menstrual cloth.

As well as being responsible for the spilling of Protestant blood the Catholic witch figure supposedly used her own blood to further her demonic aims. The English belief in the familiar, an imp or devil in the shape of an animal who was fed on the witch's blood in return for services performed on her behalf, was informed by the Continental belief in the diabolical pact. In fact, it was often thought that the familiar had been given to the witch by the Devil himself (Thomas 1971, 445-46). As Thomas points out, this belief was associated with the English notion of the witch's mark which "was sometimes thought of as a teat from which the familiar could suck the witch's blood as a form of nourishment" (Thomas 1971, 446). Deborah Willis notes that the feeding of a familiar was a demonic version of the natural process of breast feeding: "Mothers were believed to provide food for their infants by converting their blood into breast milk" and the feeding of imps by witches "inverted that process, providing blood as a substitute for milk" (Willis 1995, 52-55). ${ }^{30}$ Such diabolical suckling evokes negative English reactions to Irish Catholic nursing. As we saw in the previous chapter, the Irish nurse supposedly transmitted her seditious nature to the child she fed and she was blamed by Camden for all the social problems in Ireland. In The Faerie Queene the process of malevolent feeding is inverted when Acrasia feeds upon Verdant:

And all that while, right ouer him she hong, With her false eyes fast fixed in his sight, As seeking medicine, whence she was stong, Or greedily depasturing delight:

And oft inclining downe with kisses light, For feare of waking him, his lips bedewd, And through his humid eyes did sucke his spright, Quite molten into lust and pleasure lewd; Wherewith she sighed soft, as if his case she rewd. (2.12.73.1-9)

In his Britannia William Camden discusses the Irish diet and claims that they enjoy consuming the blood of animals:

When they are sharp set [hungry], they make no bones of raw flesh, after they have squeez'd the blood out; to digest which, they drink Usquebaugh. They let their cows blood too, which, after it is curdled, and strew'd over with butter, they eat with a good relish. (Camden 1971, 1048) ${ }^{31}$

Camden's description of the Irish appetite for blood concurs with what Richard Stanyhurst writes in Holinshed's Chronicles: 
Fleshe they deuour without bread, and that halfe raw: the rest boyleth in their stomackes with Aqua vitæ, which they swill in after such a surfet by quartes \& pottels: they let their cowes bloud, which growne to a gelly, they bake and ouerspread with butter, and so eate it in lumpes. (Holinshed [1577], D4r)

Moryson claims that famine, caused by the tactical destruction of their corn by the English, has forced the people to adopt an unnatural diet: "they besides fed not onely on Hawkes, Kytes, and vnsavourie birds of prey, but on Horseflesh, and other things vnfit for mans feeding" (Moryson 1617, Bbb2r). He further reports that a group of commanders of the forces, returning home from an expedition against the rebel Brian Mac Art, came across "a most horrible spectacle of three children (whereof the eldest was not aboue ten yeeres old), all eating and knawing with their teeth the entrals of their dead mother" (Moryson 1617, Bbb2r). Like the people of Smerwick, discussed in the previous chapter, the children have been driven to cannibalism (if we can believe the report to be true) by the trauma of famine but the cause of the cannibalism becomes lost in the description of its consequences and the overall effect of the report is to perpetuate notions of Irish barbarity. In the View Irenius claims that the Irish, like the Scythians before them, indulge in blood rituals:

Allsoe the Scythyans vsed when they would binde anie solempe vowe of Combinacion to drinke a bowle of blodd togeather vowinge theareby to spende theire laste blodd in that quarrell, And even so do the wilde Scottes as ye maie reade in Buchannan and some of the Northern Irishe likewise. (Spenser 1949, 108)

It is significant that the taboo ritual is said to be celebrated by the Northern Irish, recognised in this period as the most obdurate in their enmity toward the New English.

In Holinshed's Chronicles John Hooker gives his opinion on "The nature of the Irishmen":

And here may you see the nature and disposition of this wicked, effrenated, barbarous, and vnfaithful nation, who (as Cambrensis writeth of them) they are a wicked and peruerse generation, constant alwaies in that they be alwaies inconstant, faithfull in that they be alwaies vnfaithfull, and trustie in that they be alwaies trecherous and vntrustie. They doo nothing but imagin mischeefe, \& haue no delite in anie good thing. They are alwaies working wickednes against the good, and such as be quiet in the land. Their mouths are full of vnrightousnesse, and their toongs speake nothing but curssednesse. Their feet swift to shed blood, \& their hands imbrued in the blood of innocents. (Holinshed 1587, Ffr)

Apart from the obvious paradox that the Irish are constantly inconstant, what is apparent in Hooker's tirade is a fusion (and confusion) of the enemy as political, religious, and sexual alien. The infidelity of the Irish in political terms, that is rebellion against Elizabeth, is reconstructed in sexual terms as licentiousness. Throughout The Faerie Queene chastity and truth are under attack from inconstancy and treachery is associated with the enemies of the good Protestant knight and his lady. What we might call 'political licentiousness' is a central feature of the stories of Duessa and Acrasia and in Hooker's description of the Irish we can detect a fusion of 
the kind of negatives attributed to certain women throughout the poem. Acrasia and Duessa, and the hags Occasion (2.4), Ate (4.4), Envy and Detraction (5.12) encourage the enemies of the true knights and curse the representatives of Protestant goodness. In his images of "feet swift to shed blood" and "hands imbrued in the blood of the innocents" Hooker nods towards the resistance of the O'Neills, anticipating the guilt of Acrasia and the innocence of Amavia symbolized by the blood that stains the hands of Ruddymane.

In Holinshed's Chronicles Richard Stanyhurst writes that the English have been seduced by the Irish: "Againe, the verie English of birth, conuersant with the sauage sort of that people become degenerat, and as though they had tasted of Circes poisoned cup, are quite altered" (Holinshed [1577], D4v). Temptation and seduction are central to the depiction of Acrasia, the Circe figure in book 2 of The Faerie Queene. It is with a charmed cup that Acrasia caused the death of Mortdant (2.1.55). Excess also offers Guyon a cup of gold when he enters Acrasia's Bower: "So she to Guyon offred it to tast; / Who taking it out of her tender hond, / The cup to ground did violently cast" (2.12.57.1-3). Acrasia's attempts to drug her victims parallel those of Circe in Book 10 of The Odyssey:

She brought them in and made them sit on chairs and seats, and made for them a potion of cheese and barley meal and yellow honey with Pramnian wine; but in the food she mixed baneful drugs, that they might utterly forget their native land.

(Homer 1919, 361, lines 232-236)

Living amongst the Irish has an effect similar effect upon the English as Circe's magic has upon Odysseus' men: they are bewitched and home is forgotten. However, like the heroes Odysseus and Guyon, some men do not allow themselves to be seduced. The difference between Odysseus's men and Grille is that although the former "had the heads, and voice, and bristles, and shape of swine" they remained mentally unaffected, "their minds remained unchanged even as before" (Homer 1919, 363, lines 241-242). Grille, on the other hand, is a hog not only in his outer form but also has a "hoggish mind" (2.12.87.8). Whereas Odysseus's men are aghast at their transformation, Grille enjoys his degenerate state and when restored "Repined greatly and did him miscall, / That had from hoggish forme him brought to naturall" (2.12.86.8-9). It would appear that, although influenced by Homer's metamorphosis of men into swine, Spenser is informed to a greater extent by contemporary English disapproval of the degenerate English in Ireland.

While Spenser's depiction of Acrasia was clearly influenced by Classical myth he seems also to have been interested in the demonization of female Catholic rulers. We have already seen in the previous chapter that Spenser was responsible for the depiction of Mary Queen of Scots as the whorish witch Duessa. In John Stubbs' The Discovery of a Gaping Gulf (1579) a Catholic female ruler, Catherine de Medici, is portrayed as a witch, surrounded by familiars (Purkiss 1996, 185). ${ }^{32}$ Stubbs' book was prompted by negotiations for Elizabeth's marriage to the Catholic Duke of Anjou which was a cause of great concern for Leicester and his faction who feared Catholic toleration and a Catholic heir. Wallace MacCaffrey recounts that Elizabeth was so furious with the publication of The Discovery of a Gaping Gulf that she had the work banned, all copies confiscated, and both Stubbs and his bookseller severely punished. Both men had their right hands chopped off and Stubbs was held 
in prison until 1581 (MacCaffrey 1993, 202-03). As MacCaffrey points out, Spenser was also involved in protest against the proposed marriage: "Spenser's Shepheardes Calender (printed in 1579 but circulating in manuscript earlier) echoes the Protestants' fears in two of the eclogues; Mother Hubbard's Tale has a complex alegory involving Anjou, Burghley, and the Queen herself" (MacCaffrey 1993, 203).

If Acrasia can be identified with Catholic queens demonized in Protestant propaganda as whorish witches then her enemies in Book 2, Alma and Medina, can be read as Protestant flattery of Elizabeth. Alma not only represents the feminine soul of the male Body Politic but, like Una, is also a surrogate for Elizabeth, at one point explicitly referred to as being "like a virgin Queene most bright" (2.11.2.6). The monstrous "incontinent" mob that attacks Alma's castle is placed in direct opposition to her "sober government" (2.9.1.4). Once again political rebellion is constructed in terms of sexual rebellion, or licentiousness, as the virgin Alma resists penetration. Just as the physically deformed mob are denounced so Alma's ideal beauty is praised:

For she was faire, as faire mote euer bee, And in the flowre now of her freshest age; Yet full of grace and goodly modestee, That euen heauen reioyced her sweete face to see. (2.9.18.6-9)

Again like Una, she is not only beautiful but young and pale:

In robe of lilly white she was arayd, That from her shoulder to her heele downe raught, The traine whereof loose far behind her strayd, Braunched with gold and pearle, most richly wrought, And borne of two faire Damsels, which were taught That seruice well. Her yellow golden heare Was trimly wouen, and in tresses wrought, Ne other tyre she on her head did weare, But crowned with a garland of sweet Rosiere. (2.9.19.1-9)

Obviously white denotes virginity (Una wears it in 1.12.22.6- 7) and Alma possesses the traditional blonde hair woven into tresses to indicate her continence. Her physical attributes also suggest a religious and political dimension since Alma is linked to both Elizabeth 1 and the Virgin Mary by the pearls and roses she wears, motifs of both figures (Yates 1947, 74). ${ }^{33}$ As we have seen before, sexual purity is synonymous with beauty and truth in The Faerie Queene just as licentiousness is synonymous with ugliness and falsehood.

Before we learn the details of Alma's appearance, indication is given of her social position: "Yet was she woo'd of many a gentle knight, / And many a Lord of noble parentage, / That sought with her to lincke in marriage" (2.9.18.3-5). This may be another reference to Elizabeth but is primarily significant because it indicates that Alma is inherently superior to the "villeins" who attack her castle (2.9.13.2).

Spenser's justification for violence against the native inhabitants of Britain before the 
coming of Brutus was that their ancestry was not known whereas Brutus was "From royall stock" (2.10.9.7). The same ruthless logic applies here as throughout the View: the socially inferior or degenerate must submit themselves to the judgement of their social superiors and if they refuse to do so violence against them is justified.

Near the beginning of Book 2 Guyon is told by Amavia that Acrasia is responsible for the seduction and death of Mortdant, and therefore indirectly for her death which leaves their child an orphan (2.1.47-56). In the next canto Guyon tells Medina that the Palmer sought help in Gloriana's court:

There this old Palmer shewed himselfe that day, And to that mighty Princesse did complaine Of grieuous mischiefes, which a wicked Fay Had wrought, and many whelmd in deadly paine, Whereof he crau'd redresse.

$(2.2 .43 .1-5)$

The details of one of Acrasia's "grieuous mischiefes" have already been established in Amavia's story. The retelling by Guyon is an attempt by Spenser to emphasize the seriousness of Acrasia's crimes and give substantial motive to Guyon as a revenger of wrongs. Like Alma, Medina is a virgin antithetical to the promiscuous Acrasia. The contrast between Medina and Acrasia is most apparent in their relationship to Ruddymane: Acrasia is responsible for the death of his parents and her guilt has been projected onto his hands and Medina fulfils the role of good foster mother, an ironic inversion of Irish foster mothers vilified by early modern writers. The virgin as mother is significant because of its apparent contradiction: the hymen has not been broken, so blood, signifying the end of virginity, has not been spilled nor has the pain of bloody childbirth occurred. This contrasts with the bloody hands of Ruddymane which not only suggest violent bloodshed but are also signs of the sexual sin that surrounds him: infidelity, lust, and the sin of suicide. The virgin as mother also evokes the Virgin Mary and Queen Elizabeth as virgin mothers. In the previous chapter we saw that Elizabeth and England were constructed as good mothers in contrast to Irish mothers who were considered to be corrupt. Ruddymane is left an orphan as a direct result of his father's infidelity which in turn led to Amavia's suicide. The virgin Medina, however, presents no risk of infidelity because, unlike her sisters, she has no paramours. She is therefore a suitably chaste and temperate foster mother for Ruddymane.

In the fight between Huddibras, Sansloy, and Guyon, Medina is presented as a peace maker, which is a role Elizabeth would have identified with in relation to Ireland:

Whilst thus they mingled were in furious armes, The faire Medina with her tresses torne, And naked brest, in pitty of their harmes, Emongst them ran, and falling them beforne, Besought them by the womb, which them had borne, And by the loues, which were to them most deare, And by the knighthood, which they sure had sworne, Their deadly cruell discord to forbeare, 
And to her iust conditions of faire peace to heare.

$(2.2 .27 .1-9)$

Medina seeks peace by evoking the concept of motherhood, befitting her imminent role as Ruddymane's foster mother and evoking Elizabeth as mother of the English church and people. It is significant that Medina's sisters, in perhaps a veiled allusion to Mary Tudor and Mary Stuart, attempt to thwart her efforts to bring about concord:

But her two other sisters standing by,

Her lowd gainsaid, and both their champions bad

Pursew the end of their strong enmity,

As euer of their loues they would be glad.

(2.2.28.1-4)

Medina's plea for peace incorporates the main concern of the Ruddymane story when she refers to "bloodguiltiness":

And were there rightfull cause of difference,

Yet were not better, faire it to accord,

Then with bloud guiltinesse to heape offence,

And mortall vengeaunce ioyne to crime abhord?

O fly from wrath, fly, O my liefest Lord:

Sad be the sights, and bitter fruits of warre,

And thousand furies wait on wrathfull sword;

Ne ought the prayse of prowesse more doth marre,

Then fowle reuenging rage, and base contentious iarre.

(2.2.30.1-9)

Her entreaty sets her apart from her wrathful sisters, and her superiority is unmistakable when Guyon chooses to tell her the story of Ruddymane and entrusts the child to her care:

Then taking Congé of that virgin pure, The bloudy-handed babe vnto her truth Did earnestly commit, and her coniure, In vertuous lore to traine his tender youth, And all that gentle noriture ensu'th:

And that so soone as ryper yeares he raught, He might for memorie of that dayes ruth, Be called Ruddymane, and thereby taught, T'auenge his Parents death on them, that had it wrought. (2.3.2.1-9)

For the first time the child is named and, once again, the juxtaposition of virginity and blood is symbolic. The emphasis on Medina's virginity and the reference to her as "truth" evokes Una as Truth and the virgin of Book 1. That Ruddymane is supposed to "auenge his Parents death on them, that had it wrought" is at first puzzling because Guyon carries out this revenge when he captures Acrasia and destroys the Bower of Bliss. The double function of Ruddymane only becomes clear by the end of 
the book: his role is to be a justification for Guyon's violent action without pity in the Bower of Bliss and an emblem of the innocence of Amavia and of the guilt of Acrasia.

In Renaissance Self-Fashioning Stephen Greenblatt recognises an Irish dimension in Book 2 and finds motive for the destruction of the Bower of Bliss in the perceived threat of absorption which demands identification and destruction of the demonic Other (Greenblatt 1980, 178). The ever present threat of seduction partly explains the ferocity of Guyon's actions. As Greenblatt states "Pitiless destruction is here not a stain but a virtue" (Greenblatt 1980, 187). Though not stressed by Greenblatt, there is a strong link between Guyon's aggression and the violence without pity perpetrated by Talus and condoned by Artegall in Book 5. Critical consensus tells us that Book 5 is the Irish book but the aggressive actions of Guyon prefigure the behaviour of Artegall's servant, Talus:

But all those pleasant bowres and Pallace braue, Guyon broke downe, with rigour pittilesse;

Ne ought their goodly workmanship might saue Them from the tempest of his wrathfulnesse, But that their blisse he turn'd to balefulnesse: Their groues he feld, their gardins did deface, Their arbers spoyle, their Cabinets suppresse, Their banket houses burne, their buildings race, And of the fairest late, now made the fowlest place. (2.12.83.1-9)

As we shall see later, the excessive violence of Guyon in the Bower is mirrored in Book 5 by the savage death of Munera (5.2.25-27), the attack on Radigund's women (5.4.44.1-9) and other acts of brutality perpetrated by Talus. Spenser's apology for the violence of Artegall (Lord Grey) who controls Talus might be extended to Guyon also. ${ }^{34}$ The principle that justice and vengeance must not be undermined by pity is evident in the View and A Brief Note where flattery only thinly veils criticism of Elizabeth's compassion for her Irish subjects. In the View Eudoxus expresses concern that such pity will halt the progress of the tactical famine proposed by Irenius to starve the Irish into submission:

if it shall happen that the state of this miserye and lamentable image of thinges shalbe tolde and felingelye presented to her sacred maiestye beinge by nature full of mercye and Clemencye whoe is moste inclynable to suche pittifull Complaintes ... then shee perhaps for verye Compassion of suche Calamities will not onelye stopp the streame of suche violence and retorne to her wonted mildenes, but allso con them litle thankes which haue bene the Aucthors and Counsellours of suche blodye platformes. (Spenser 1949, 159)

Both Irenius and Eudoxus praise Lord Grey, criticized by some for his savagery against the Irish people: "He noble Lord eftsones was blamed [and] the wretched people pittied . .." (Spenser 1949, 160). Similarly in A Brief Note Elizabeth is told that her clemency has been misplaced because the Irish are not worthy of pity: "Whereas your Maiestie as you haue hitherto made your selfe through all the worlde a gloriouse example of mercie and Clemencye and euen vnto these vile Catifes 
Fitzpatrick, Joan. 2000b. Irish Demons: English Writings on Ireland, the Irish and Gender By Spenser and His Contemporaries. Lanham. University Press of America.

(though moste vnworthie thereof) . .." (Spenser 1949, 241, lines 224-226). Elizabeth is called upon to take violent action against those who have abused her compassion:

So nowe by extending vpon them the terror of your wrath in avengement of there continuall disloyalltie and disobedience you shall spreade the honorable fame of your lustice and redeeme both your owne honour and allso the reputacion of your people ... (Spenser 1949, 241, lines 226-230)

As in the "Supplication" this call for vengeance fuses the political and sexual concepts of loyalty, honour, and reputation. The Irish have been unfaithful to their queen and must be punished. At the same time, Elizabeth is constructed as a mother figure who must discipline her wayward children for their disobedience.

As well as echoing aspects of the political situation in early modern Ireland the Ruddymane episode suggests a connection with Shakespeare. This chapter will conclude with a consideration of the Ruddymane episode and the Murrogh O'Brien episode from the View and consider the relevance of these bloody episodes upon Shakespeare's Macbeth.

The Ruddymane episode in Book 2 of The Faerie Queene and Shakespeare's Macbeth share a Gaelic context in their explication of a supposed Gaelic barbarism. In his nineteenth-century edition of The Faerie Queene H. J. Todd compares Guyon's inability to clean blood from the hands of Ruddymane with Macbeth's remark after he has murdered Duncan ("Will all great Neptunes Ocean wash this blood / Cleane from my Hand?", Shakespeare 1623, mm3r; 2.2.58-59) and Lady Macbeth's soliloquy in the sleep-walking scene: "Out, damned spot . . . What will these hands ne're be cleane?" (Shakespeare 1623, nn2v; 5.1.41). Yet Todd does not consider the Ruddymane episode as a whole, nor the episode and play together in any detail and he does not come to any conclusions about Shakespeare's debt to Spenser. Furthermore, Todd's remark is buried in an edition of the poem which is not readily available (Todd 1805, 262) and in the Spenser variorum, unseen by most Shakespeare scholars (Spenser 1933, 196).

Andrew Hadfield suggests that the description of the actions of Murrogh O'Brien's foster mother in Spenser's View (c. 1596)—which as we saw in the previous chapter endorsed English opinion of the Irish as savages-bears remarkable resemblance to an anonymous account of the execution of the martyred Jesuit, Robert Southwell. Hadfield compares the dipping of handkerchiefs in Southwell's blood by members of the attendant crowd with the drinking of O'Brien's blood by his foster mother (Hadfield 1999). A link can also be made between the episode featuring O'Brien in Spenser's View and the Ruddymane episode. In the View Irenius tells Eudoxus that at the execution of O'Brien in Limerick

... I sawe an olde woman which was his foster mother take vp his heade whilste he was quartered and sucked vp all the blodd rvnninge theareout Sayinge that the earthe was not worthie to drinke it and thearewith allso steped her face, and breste and torne heare Cryinge and shrikinge out most terrible/ (Spenser 1949, 112).

Of course the Ruddymane episode also features a bloody mother and child: 
Pittifull spectacle of deadly smart,

Beside a bubbling fountaine low she lay,

Which she increased with her bleeding hart,

And the cleane waues with purple gore did ray;

Als in her lap a louely babe did play

His cruell sport, in stead of sorrow dew;

For in her streaming blood he did embay

His litle hands, and tender ioynts embrew;

Pitifull spectacle, as euer eye did view.

(2.1.40.1-9)

If we agree that the Ruddymane episode is echoed in the episode featuring O'Brien in the View it is entirely possible that Shakespeare was influenced not only by the episode featured in The Faerie Queene but by a similar passage in the prose text. Although the View was not published until 1633 it was certainly circulating in manuscript and would have been entirely appropriate preparatory reading for Shakespeare's play about Gaelic savagery. Despite Jean Brink's suggestion that Spenser did not write the View, similarities between the bloody mother and child in the View and the bloody mother and child in The Faerie Queene suggest a single author (Brink 1994). At the very least the parallel indicates that the Ruddymane episode influenced whoever was responsible for the composition of the View.

Spenser's familiarity with the Red Hand as a signifier of Gaelic pride and resistance undoubtedly led him to present it in the Ruddymane episode as a symbol of sin. That Shakespeare too would have been interested in Irish symbols when writing Macbeth is entirely possible. Spenser perceived a common ancestry between the Irish and the Scots: in the View Irenius tells Eudoxus that both the Scots and the Irish are derived from the barbarous Scythians who arrived first in Ireland and later proceeded into Scotland (Spenser 1949, 83).

It seems that Shakespeare, like Spenser, was particularly interested in the symbolic potency of hands stained with blood. In the Ruddymane episode water carries a spiritual significance in that it will not permit its pollution by blood. Like Guyon, Lady Macbeth thinks that washing the blood from her hands is a practical matter-"A little water cleares vs of this deed" (Shakespeare 1623, mm3r; 2.2.65) only to discover that physical cleanliness is no index of absolution. Macbeth's anxiety that the blood on his hands will entirely pollute the water-"Making the Greene one, Red" (Shakespeare 1623, mm3r; 2.2.61)—echoes the Ruddymane episode in imagining symbolic guilt as transferable and indelible. Shakespeare took the notion of blood that will not wash off and used it for psychological metaphor. The unseen force that keeps the blood on the hands of Ruddymane is the force that keeps Macbeth and Lady Macbeth restless. Initially, but only temporarily, the Macbeths succeeded in transferring suspicion of guilt by besmirching Duncan's innocent attendants with blood. In both stories children are the victims of the bloody violence initiated by witches and are the provocation for promises of retribution: by Guyon (2.1.60-61) and Macduff (4.3.232-237). Of course 'blood' also connotes lineage, a primary concern for Spenser in both The Faerie Queene and the View and crucial to the ambitions of Macbeth. 
In his section on the analogues to Macbeth under the heading 'Bloodstained Hands', Geoffrey Bullough does not mention the Ruddymane episode despite its obvious parallels with Shakespeare's play (Bullough 1973, 523-26). The precedence of Spenser's poem makes Shakespeare the borrower: the first edition of Books 1-3 of The Faerie Queene was published in 1590 and Macbeth is thought to have been composed in 1606, although not published until 1623 in the First Folio (Wells et al. 1987, 128-29).

The aggressive retributive actions of Guyon against Acrasia, a symbol of supposed Catholic corruption in Book 2, prefigures the violent impulses directed toward the Catholic Irish in Book 5 of The Faerie Queene and throughout the View. Bloody violence, in the context of Gaelic barbarism and its links with witchcraft, rebellion, and murder reverberates through Macbeth and suggests an important debt Shakespeare owed to Spenser in his retelling from Holinshed of this tale of Celtic bloodshed.

\section{Chapter 4}

Gendered Histories: Nicolas Sander, Shakespeare, and the PostReformation Propaganda War

In his Letter to Raleigh (1589) Spenser asserts that Elizabeth is "a most vertuous and beautifull Lady" and will be represented in his poem by Belphoebe (Spenser 1977, 737). In the proem to Book 3 the narrator presents Elizabeth as a paragon of virtue who can see herself in more than one mirror: "But either Gloriana let her chuse, / Or in Belphobe fashioned to bee: / In th'one her rule, in th'other her rare chastity" (3.1.Proem.5.7-9). Gloriana is mentioned three times in the poem but never actually appears, her insubstantiality suggesting that Spenser wished to emphasize the private chastity of Elizabeth as Belphoebe, thus making the queen's sexual purity a symbol of her power. ${ }^{35}$ The depiction of Belphoebe is typical of one kind of rhetoric 
surrounding Elizabeth, but existing alongside encomiums of her virtue was antiProtestant polemic denouncing both the queen and her parents as villains. Much of this material centred on the defense of the Catholic Mary Stuart. ${ }^{36}$ John Leslie's defence of Mary was published anonymously in 1569 and revised in 1571 with a more hostile attitude toward England and Elizabeth. Adam Blackwood's account of the martyrdom of Mary was published in the year of Mary's death. ${ }^{37}$ James Emerson Phillips argues that these works were the principal sources for future pro-Marian historians (Phillips 1964, 100-07). Blackwood also appears to have been primarily responsible for the preparation of a series of poems written by Catholic propagandists on the death of Mary. ${ }^{38}$

An influential example of the kind of anti-Protestant polemic which denounced Elizabeth and her parents is Nicolas Sander's Rise and Growth of the Anglican Schism (De Origine ac Progressu Schismatis Anglicani). Sander's book, which had been left unfinished due to his death in 1581, was edited and published in Latin, first in one volume by Edward Rishton in 1585, then in three volumes by Robert Persons in 1586. Sander demonstrates little of the reserve evident in the works of Leslie and Blackwood, as James Emerson Phillips points out: "Where Leslie and even Blackwood were cool but cautious in their references to the English Queen, Sander makes her the chief villain of the piece" (Phillips 1964, 110). In a survey of printed sources of Elizabethan religious polemic Peter Milward says of Sander's work: "It rapidly became the most popular book on England in sixteenth- century Europe, going into fifteen editions-including translations into French, Spanish, Italian and German—within ten years of its first appearance" (Milward 1977, 71). Phillips notes that Sander was probably the first propagandist to print the story that Elizabeth was conceived unlawfully:

He publishes for the first time, and as fact, a mixture of fact, legend, and conjecture about her that was to become basic material in much of the literature produced by Mary's apologists after her execution. He was, for example, probably the first propagandist to print the story that Elizabeth was the child of a union that was not only adulterous, as all Catholics have held Henry's connection with Anne to be, but bigamous and incestuous as well. (Phillips 1964, 110)

Sander claimed that Elizabeth's father, Henry, had an affair with Anne Boleyn's mother, Elizabeth, wife of Thomas Boleyn, whilst still married to Katherine of Aragon. This meant that he was guilty not only of adultery but subsequently incest by having sexual intercourse with his own daughter, Anne, the result of this liaison. These charges were used by Sander to defend his claim that Elizabeth Tudor was illegitimate and the result of an incestuous relationship.

Sander, the papal legate, was amongst the Spanish and Italian party that landed at Smerwick in 1579 to support the Munster rebellion. The invading force was defeated, and they surrendered, but all, apart from the officers, were slaughtered. The order to kill those who pleaded for mercy came from Lord Deputy Grey who subsquently denied claims that they had been promised their lives. He further asserted that the party was not a legitimate army and thus did not deserve any mercy. Grey ordered that any Irish, including women, discovered in the fort should be hanged. One of the victims, according to Pauline Henley, was a servant of Sander (Henley 1928, 27). Sander was not killed at Smerwick but died in Ireland a 
short time after, no one is quite sure exactly when. At the time of the massacre Spenser was employed by Grey as his secretary and Grey's actions at Smerwick are defended by Irenius in the View who claims that "theare was no other waie but to make that shorte ende of them which was made" and asserts that Grey is a "most iuste and honorable personage" (Spenser 1949, 161-62). In a thinly veiled allusion to the circumstances surrounding Grey's recall from Ireland he is similarly defended against Detraction and Envy in Book 5 of The Faerie Queene (5.12.27-43). Given its popularity and reputation it is unlikely that Spenser was unaware of Sander's work which appeared in Latin five years before the publication of Books 1-3 of The Faerie Queene. The logic behind this chapter is that Spenser was encouraged by the kind of anti-Protestant rhetoric evident in Sander's history to launch a counter-attack in defence of Elizabeth.

Sander's pejorative depiction of Elizabeth and her mother Anne Boleyn can be fruitfully compared with Spenser's literary depictions of these women as Belphoebe and Chrysogone in The Faerie Queene in order to understand how female sexuality is used for political purposes. In this light, Spenser's poem can be seen as a contribution to the post-Reformation propaganda war through which he answers the propagandists' defamation. As we shall see later, Shakespeare's depiction of Anne Boleyn in All is True (King Henry 8$)^{39}$ is another example of literary biography which answers the defamation of Elizabeth's mother although Shakespeare was not above defamation himself, as his positively anti-Catholic depiction of Joan La Pucelle in 1 Henry 6 demonstrates. ${ }^{40}$

When reporting the history of Belphoebe the narrator states that she was blessed before her birth by the position of the heavens as they bestowed upon her the gifts of grace and chastity. Chastity defines the nature of both Belphoebe and Amoret, her twin. Most significantly, they have been conceived without the act of sexual intercourse and so are without the taint of original sin:

Her berth was of the wombe of Morning dew, And her conception of the ioyous Prime, And all her whole creation did her shew Pure and vnspotted from all loathly crime, That is ingenerate in fleshly slime. (3.6.3.1-5)

The flesh of humanity, regarded as sinful by the Christian Church, has been avoided by both twins who have absorbed the chaste nature of their mother Chrysogone whose name translates from the Greek as 'golden-born' (Draper 1932, $100)$, suggesting her impregnation by the sun. The story has unmistakable classical and religious resonances, suggesting the myth of Danae-where Jove transformed himself into a shower of gold in order to have sex with her (Spenser 1977, 355)—and the Graeco-Roman myth of Latona, the lover of Jupiter and mother of the twins Apollo and Diana. In "Amoret and Belphoebe: Fairy Tale and Myth" Linda Woodbridge claims that Spenser's story is adapted from one of the older versions of Sleeping Beauty which is itself a variant of the myth of Latona (Woodbridge 1986, 340). Woodbridge notes that one of Apollo's titles is 'Chrysocomes' which means 'of the golden locks' and this may have suggested the name to Spenser (Woodbridge 1986, 341). In From the Beast to the Blonde Marina Warner describes the system of 
Fitzpatrick, Joan. 2000b. Irish Demons: English Writings on Ireland, the Irish and Gender By Spenser and His Contemporaries. Lanham. University Press of America.

values that operate around fairness and the blondness of hair and cites the Greek romance of Aethiopica by Heliodorus:

. . . the plot turns on a lost daughter, the child who was born fair-skinned to her royal Ethiopian parents after her mother during her conception contemplated a painting of the classical, blonde Andromeda. Much is made of the improbability of her belonging to them, until her unique birthmark is recognized and the right cradle tokens brought forth. (Warner 1995, 364-65) ${ }^{41}$

Spenser was probably familiar with this popular tale which had been translated into English in 1587 (three years before the publication of Books 1-3 of The Faerie Queene). In the western tradition, female beauty is typically identified with fair skin and fair hair, which are attributes possessed by Una (1.1.4). Physical fairness implies sexual purity and, as with Petrarchan rhetoric, that which is constituted as morally or spiritually valuable is conveyed through analogy with what is economically valuable: the fair-haired woman is said to have 'golden' locks . ${ }^{42}$

Chrysogone's moral value is demonstrated in her chastity, allowing for a deeper symbolism of her name which reflects that moral value. The story of Belphoebe's conception also carries strong religious resonances, recalling as it does the traditional emphasis placed on virginity by the Christian Church. In Alone of all her Sex: The Myth and the Cult of the Virgin Mary Marina Warner explores the history of the concept of Mary's Immaculate Conception whereby it was claimed that Christ's mother was not only a virgin but was herself preserved from original sin from the moment of conception (Warner 1990, 236-54). Like the Virgin Mary, Chrysogone as a virgin mother is said to have conceived without pleasure and given birth without pain (3.6.27.1-3). With its contradictory emphasis on the value of both virginity and motherhood, the story of Belphoebe's conception echoes the Protestant construction of Elizabeth as both Virgin Queen and mother of her people. As we saw in chapter 1, Elizabeth was often constructed as mother of the English church and people.

Helen Hackett disputes the view that a cult of Elizabeth simply replaced the cult of the Virgin Mary, traditionally the figure who embodied the contradictory qualities of virginity and motherhood. ${ }^{43}$ She challenges the theory that Elizabeth became a Protestant substitute for the Virgin Mary "filling a post-Reformation gap in the psyche of the masses, who craved a symbolic virgin-mother figure" $(1995,7)$. Moreover, she asserts that the representation of Elizabeth as nursing mother draws not only on Marian iconography but also Isaiah 49:23, "a key biblical text for the Protestant reformers" 44 Yet although Hackett denies that one cult simply replaced another, she admits that Spenser's description of Belphoebe "comes closest to echoes of Mariology" and his account of her conception and birth "like that of Elisa in the 'April' Eclogue, draws on the idea of the Immaculate Conception" (Hackett 1995, 141). As we saw in the previous chapter, Medina is another example of a virginal mother figure who, in contrast to the seductive Acrasia, cares for the child Ruddymane.

'Belphoebe' comes from the Latin for 'handsome' and the Greek for 'pure, radiant' (Draper 1932, 100). Her chastity is evident in the brightness emanating from her person, an inner beauty which can be perceived in her physical beauty. For those who can read the signs, the physical beauty of degenerate figures, such as Duessa and the False Florimell, lacks this brightness because they are not chaste. In 
accordance with Neoplatonic tradition the physical beauty of Belphoebe and Amoret is a manifestation of their spiritual and moral goodness:

These two were twinnes, and twixt them two did share

The heritage of all celestiall grace.

That all the rest it seem'd they robbed bare

Of bountie, and of beauty, and all vertues rare.

(6.4.6-9)

Their beauty and their virtue are equally stressed because, for Neoplatonists, true beauty depends on virtue.We know that Spenser intended Belphoebe to be a compliment to the beauty of Elizabeth, yet the compliment goes beyond mere physical description: it is a declaration of her chastity which indicates her moral goodness and thus her strength to lead the Protestant people. To compliment Elizabeth's beauty, allegorized in the beauty of Belphoebe and the story of her virgin birth, is to emphasize the exceptional nature of Elizabeth as female ruler.

Neoplatonic theory states that physical beauty, as an indication of spirtual 'goodness', would encourage the viewer to consider divine beauty, that is, God. This is particularly pertinent in the case of Elizabeth because she was Supreme Governor of the True Church. Contemplation of the queen's beauty takes the Neoplatonic theory one step further than is usual for in the depiction of Belphoebe, the reader contemplates God's sole representative on earth.

In his 1758 edition of The Faerie Queene John Upton denies any possiblity that Chrysogone might represent Anne Boleyn: "Belphoebe is Q. Elizabeth; if we carry on the allusion Chrysogone should be Anna Bullen: but this will not hold true, no more than Amorett is Queen Mary, because said here to be sister of Belphoebe" (Upton 1987b, 718). Upton is quite wrong to claim that Chrysogone cannot represent Anne Boleyn although he is correct in his assertion that Amoret in no way represents Elizabeth's sister Mary. Why Spenser should present Belphobe (Elizabeth) as a twin is not clear but the thrust of the allegory is to depict Elizabeth (Belphoebe) born of a virtuous mother as a general compliment to Elizabeth via Anne Boleyn. The allegory at this point does not extend to Mary or to her mother Katherine of Aragon.

Argante and Ollyphant, the second set of twins in Book 3, are antithetical to Belphoebe and Amoret. Just as chastity is the overall defining aspect of the nature of Chrysogone's offspring, so incest can be said to be the overall defining aspect of these twins. It is significant that the antithesis between the sets of twins is underlined etymologically: the Latin derivation of 'incest' is given in the OED as "from in- (IN-3) + castus chaste, pure", thus impure, unchaste. We hear a detailed account of the conception and birth of the incestuous twins from the Squire of Dames, which is ironic given that the Squire himself is associated with lechery. ${ }^{45}$ The squire relates that Argante is the daughter of a Titan and her birth was the result of an incestuous union between mother and son:

Her sire Typhoeus was, who mad through merth, And drunke with bloud of men, slaine by his might, Through incest, her of his owne mother Earth Whilome begot, being but halfe twin of that berth. (3.7.47.6-9) 
According to $\mathrm{W}$. Arens, incest between a mother and her son is generally regarded as the most extreme violation of the incest taboo: "Mother-son incest is an expression of the breakdown of all rules, and thus chaos. As such, it is unimaginable in some societies, while in others it is an indication of madness-a personal chaos" (Arens 1986, 145). We should note that Typhoeus, as a Titan, had taken part in an insurrection against heaven, an endeavour to subvert the proper social order; Catholics would have considered Henry 8 to have done the same. In the preface to The Rise and Growth of the Anglican Schism, Sander is unequivocal in his accusations that Anne was guilty of sexual promiscuity and incest. Like Argante, her lust recognizes no boundaries: "Anne Boleyn had sinned with many before marriage, and after her marriage with the king she sinned with her own brother" (Sander 1877, cxlvi). Moreover, her sexual exploits began at an early age:

At fifteen she sinned first with her father's butler, and then with his chaplain, and forthwith was sent to France ... Soon afterwards she appeared at the French court, where she was called the English mare, because of her shameless behaviour; and then the royal mule, when she became acquainted with the King of France. (Sander 1877, 25-26)

Anne's behaviour is associated with her nationality, the use of the term 'English mare' allowing a fusion of national and sexual epithets which reveal the politicial dimensions of the sexual labelling. Before the Reformation, the application of Marian iconography to royal women was not unusual and was used in honour of Anne Boleyn at her coronation. ${ }^{46}$ Sander inverts allusions to the Virgin Mary by demonizing Anne. He juxtaposes the traditional virginity of Christ's mother with the alleged sexual experience of Anne and the traditional modesty of the Virgin Mary with Anne's supposedly flirtatious nature:

The more the king sought her, the more she avoided him, sanctimoniously saying that nobody but her husband should find her alone; nevertheless she did not think there was any want of modesty in talking, playing, and even in dancing with the king. In this way she so fed the fires of the king's passion that he became more and more determined to put away Catherine his wife, and to put a woman of such admirable modesty in her place. (Sander 1877, 26)

Like Duessa and Acrasia, Anne is a seductress who hides behind feigned modesty in order to lure and destroy unsuspecting men. In contrast, Spenser depicts Chrysogone and Belphoebe (Anne and Elizabeth) as pure and bright, connoting all that is virtuous.

In an attempt to discredit Elizabeth, Sander characterizes her father as lascivious and undiscriminating in his choice of sexual partners:

Meanwhile Henry was giving the reins to his evil desires, and living in sin, sometimes with two, sometimes with three of the queen's [Catherine's] maids of honour, one of whom, Elizabeth Blount, gave birth to a son, whom Henry made duke of Richmond. (Sander 1877, 8)

Sander implies that it was Henry's lascivious nature, his lust for Anne Boleyn rather than a pricked conscience about marrying his brother's wife, that resulted in his 
insurrection against the Catholic Church, viewed by Sander as a subversion of the proper social and religious order: "Henry then, in order to marry this woman, put away Catherine, and apostatised from the Roman Church" (Sander 1877, cxlvi). Henry is characterized by Sander as a liar:

Henry, therefore, who, against the law of nature in a certain sense, dared to marry the daughter of the mother he had defiled, was simply shameless when he pretended that he durst not keep his wife Catherine because he feared to sin against God; shameless also when he feigned to believe that it was not in the power of the Pope to sanction his marriage with Catherine. (Sander 1877, 99)

Given that Typhoeus is the father of the extreme enemy of chastity, Spenser appears to be ascribing to Elizabeth's enemies the very qualities that polemicists like Sander ascribed to her and her parents. If Elizabeth's enemies are unchaste and evil it serves to highlight her chastity and goodness, and therefore her fitness to reign.

The squire of Dames outlines the incestuous behaviour of Argante and her male twin Ollyphant in their mother's womb:

These twinnes, men say, (a thing far passing thought)

Whiles in their mothers wombe enclosd they were, Ere they into the lightsome world were brought, In fleshly lust were mingled both yfere, And in that monstrous wise did to the world appere. (3.7.48.5-9)

The foetuses are apparently marked by the degenerate behaviour of their parents and behave likewise. Sander claimed that Elizabeth was tainted not only because the marriage of Henry and Anne Boleyn had been declared unlawful by Clement 7 (Sander 1877, 229) but also because Anne Boleyn was actually Henry's daughter:

It is clear from what we have already said that Henry was told in no doubtful way that Anne Boleyn was his own child, and yet he married her ... We further declare by the same sentence that the children, born or to be born of that marriage, are and have always been bastards. (Sander 1877, 99-103)

Elizabeth was, according to Sander, not only the illegitimate result of a fraudulent marriage but also the product of an incestuous relationship. Furthermore, Edward Rishton, who completed Sander's history by the addition of a fourth book published with Sander's in 1585, implied that Elizabeth had inherited the lustful nature of her father and mother. This lustfulness was evident in her decision not to marry which allowed her to indulge in "this pretence of a single life" (Sander 1877, 288). Spenser challenges such allegations against Elizabeth by presenting the enemies of chastity as degenerate and so answers any improper allegations against Elizabeth by Catholic polemicists such as Sander. A similar process is evident in Sander's claim that, as a punishment from God, Henry's children (even the Catholic Mary) were destined to be childless: "It was the will of God that Henry VIII., for his sins and for the schism, should be thus severely punished; for though when he died he left three children living-Edward, Mary, and Elizabeth-yet of none of them might a child be born and reared" (Sander 1877, 229). Even though Elizabeth's 
childless state was interpreted by enemies like Sander as divine punishment, Elizabeth and her supporters managed to present it in a positive light by depicting her as a more devoted (because single) wife and mother to the English Church and people.

As giants, Argante and Ollyphant are physically grotesque and their incestuous behaviour is an indication of their moral corruption. The proverbial bond between twins is here made obscene by their perverse behaviour in the womb which is envisaged as dark and sinister, a secretive place where the most secretive of acts can occur. The incestuous twins compound their sin by continuing their unnatural behaviour beyond the womb: "So liu'd they euer after in like sin, / Gainst natures law, and good behauioure" (3.7.49.1-2). Dark acts in dark places by grotesque figures recall Error and the actions of her brood in her womb-like cave (1.1.13-15). The act of incest is not only a deviation from the laws of nature but also breaks a strong social taboo and so the incestuous twins are guilty of social rebellion. Yet it is the female twin Argante who, according to the squire, is the most degenerate of the two. Throughout the poem sexual promiscuity is gendered. The most threatening figures in previous books have been sexually promiscuous women: the whorish witches Duessa and Acrasia. Argante not only violates the incest taboo but indulges in bestiality. Worst still, she is a manifestation of that most terrifying of male fears, the sexually insatiable female:

But greatest shame was to that maiden twin, Who not content so fowly to deuoure Her natiue flesh, and staine her brothers bowre, Did wallow in all other fleshly myre, And suffred beasts her body to deflowre:

So whot she burned in that lustfull fyre, Yet all that might not slake her sensuall desyre. (3.7.49.3-9)

Argante's lack of chastity manifests itself in masculine aggression as she travels Fairyland seeking young men to satisfy "her flaming thrust". The language is phallic, the "flaming thrust" describing not only her sexual strength but also her inversion of the male/female hierarchy:

Whom so she fittest finds to serue her lust, Through her maine strength, in which she most doth trust, She with her brings into a secret lle, Where in eternall bondage dye he must, Or be the vassall of her pleasures vile, And in all shamefull sort him selfe with her defile. (3.7.50.4-9)

The Catholic Irish-who similarly wish to subvert what are deemed divinely ordained hierarchies-were often accused of being licentious and even incestuous by early modern English commentators. As Nicholas Canny points out: "Incest was said to be common among them, and Gaelic chieftains were accused of debauching the wives and daughters of their tenants ..." (Canny 1976, 127). 
Incest has often been associated with another 'savage' activity: cannibalism. W. Arens suggests two reasons for the cannibalism-incest equation: firstly, both indicate a lack of culture and so those accused of being cannibals were also accused of having no incest taboo; secondly, in many cultures there is what Arens calls "a symbolic equation between sex and eating" so that the idea of one family member devouring another is horrific (Arens 1979, 146-47). The Squire of Dames claims that Argante's father, Typhoeus, was "mad through merth, / And drunke with bloud of men, slaine by his might" (3.7.47.6-7) when he committed incest with his mother and although Typhoeus's drinking of blood might be metaphorical it suggests

cannibalism. Argante's sexual exploits similarly evoke cannibalism: Who not content so fowly to deuoure / Her natiue flesh, and stain her brothers bowre, / Did wallow in all other fleshly myre" (3.7.49.4-6). Her incestuous and bestial activities place Argante beyond social and cultural boundaries. As Arens points out, the construction of social groups as barbaric and cannibalistic denies them their humanity because it "sweeps them outside the pale of culture and places them in a category with animals" (Arens 1979, 140). Fynes Moryson and Barnaby Rich compared the Irish to beasts. In his Itinerary, Moryson claimed that "these wild Irish are not much vnlike to wild beasts" (Moryson 1617, Sss3v) and in A Short Survey of Ireland Barnaby Rich denounced the Irish as "more brutish in their customes and demeanures, then in any other part of the world that is knowne" (Rich 1609, B1v).

The third pair of twins is constructed rather than born and differ from the chaste twins and the incestuous twins in that the pair are opposites of each other. The chaste Florimell is the antithesis of the False Florimell who is her malevolent double. Florimell is also the physical and spiritual opposite of the forester who pursues her in an effort to rape her. She is described as a great beauty who flees from his lust:

All suddenly out of the thickest brush, Vpon a milk-white Palfrey all alone, A goodly Ladie did foreby them rush, Whose face did seeme as cleare as Christall stone And eke through feare as white as whales bone: Her garments all were wrought of beaten gold, And all her steed with tinsell trappings shone, (3.1.15.1-7)

The description of her beauty-which contrasts with the repulsive appearance of the "griesly" forester (3.1.17.2) —not only recalls the description of Una's whiteness (1.1.4), but also Petrarchan images of precious stones and metals common in the rhetoric praising Elizabeth. A further link with Elizabeth is made when Florimell, like Una (1.1.5), is described as being "Royally clad" (3.5.5.2), reminding us that Una "from Royall lynage came / Of ancient Kings and Queenes, that had of yore / Their scepters stretcht from East to Western shore" (1.1.5.3-5). The possibility that Florimell is also a symbol of the New English, as representatives of Elizabeth, under threat of violence from a savage woodland dweller, is considered in the next chapter.

The False Florimell, also called the Snowy Florimell, is a monstrous parody of the real Florimell and thus her enemy. Its creation is a parody of the 'natural' and divinely ordained act of conception and birth because it is conceived by a witch with her sprites and brought forth via black magic. The materials used to construct the False 
Florimell are similarly parodies of what constitutes ideal beauty in

Petrarchan rhetoric, just as the Catholic church was considered by some Protestants to be a parody of the true religion. Its body is made from "purest snow" tempered with mercury and virgin wax mingled with vermillion (red sulphide) to create the perfect complexion. The artifice of the creation is emphasized:

In stead of eyes two burning lampes she set

In siluer sockets, shyning like the skyes,

And a quicke mouing Spirit did arret

To stirre and roll them, like a woman's eyes;

In stead of yellow lockes she did deuise,

With golden wyre to weaue her curled head;

(3.8.7.1-6)

The traditional motif of the lady's eyes as stars or bright lights, used repeatedly for example in Sidney's Astrophel and Stella, is inverted: instead of having eyes like lamps the creature has lamps like eyes, instead of having hair like golden wire it has wire like golden hair. It is an embodiment of an inverted Petrarchan poem and suggests a mistrust of artifice that attempts to mimic nature.

Although the False Florimell is a copy of Florimell, the witch cannot exactly reproduce her beauty because art falls short of nature: "Yet golden wyre was not so yellow thrise / As Florimells faire haire" (3.8.7.7-9). The onus is on the viewer to reach beyond the mortal senses to perceive whether apparent beauty is genuine or a counterfeit, that is, whether the virtue on which true beauty depends is present. ${ }^{47}$ The shape from which the witch builds her counterfeit, and into which the sprite will breathe life, is referred to as a dead carcass: it does not have a soul and so is morally defunct. It is significant that the False Florimell is referred to as an "idole" (3.8.11.2) invoking the idolatry of which Catholicism was frequently accused and recalling the profane worship of Una by the Saluage Nation in Book 1, discussed in chapter 2.

R. W. Church asserts that the False Florimell connotes Mary Stuart "stirring up strife, and fought for by the foolish knights whom she deceives, Blandamour and Paridell, the counter parts of Norfolk and the intriguers of 1571" (Church 1887, 128). This identification is consistent with the poem's repeated allusions to Catholicism, yet the twin motif suggests that the False Florimell may also represent Elizabeth's sister, Mary Tudor. England was temporarily ruled by Mary, the Catholic imposter, and this temporary usurpation of the true faith is allegorized in Book 5 when Braggadochio claims that the False Florimell is superior to the true Florimell. The people have been deluded for some time by a 'false queen':

As when two sunnes appeare in the azure skye, Mounted in Phoebus charet fierie bright, Both darting forth faire beames to each mans eye, And both adorn'd with lampes of flaming light, All that behold so strange prodigious sight, Not knowing natures worke, nor what to weene, Are rapt with wonder, and with rare affright.

So stood Sir Marinell, when he had seene 
Fitzpatrick, Joan. 2000b. Irish Demons: English Writings on Ireland, the Irish and Gender By Spenser and His Contemporaries. Lanham. University Press of America.

The semblant of this false by his faire beauties Queene.

(5.3.19.1-9)

Artegall declares the False Florimell a fraud and when judged by Artegall against the true Florimell, the imposter disappears into thin air:

Then did he set her by that snowy one, Like the true saint beside the image set, Of both their beauties to make paragone, And triall, whether should the honor get.

Streight way so soone as both together met, Th'enchaunted Damzell vanisht into nought: Her snowy substance melted as with heat, Ne of that goodly hew remayned ought, But th'emptie girdle, which about her wast was wrought. (5.3.24.1-9)

Just as the False Florimell is a demonic parody of the true Florimell, so the Catholic queen Mary was considered merely an "image" of the true queenship evident in the reign of Elizabeth, considered a "true saint" by the Protestant faithful.

Sander presents Mary in much the same light as her mother, Catherine of Aragon, whom he describes as a saint-like figure devoted to her Catholicism. Stressing the chastity of Catherine, Sander denounced the licentiousness of Henry: "Catherine's life was one of soberness and modesty, that of the King one of levity and wantoness" (Sander 1877, 11). Sander, like the Catholic Church, recognized the validity of the marriage of Henry and Catherine and therefore Mary's right to the throne $(1877,10)$. Elegizing the death of Mary, he states:

God had raised up this most saintly woman, and placed her in the midst of the Anglican schism as a faithful sign, to the great consolation of the Catholics, that they might not be discouraged and crushed under the burden of heresy. . . . Then came the hour of Satan, and the power of darkness took possession of the whole of England. (Sander 1877, 232-33)

For Sander, Elizabeth is the devil and Mary a saint. The concept of twin Florimells allows Spenser to reverse the deification of Mary, evident in Catholic propaganda, and to demonize the Catholic enemies of the True Church, just as Sander demonized Protestantism and it adherents.

In order to demonstrate that historical portraits are politically biased depending on the sympathies of the writer in question, and that some writers use sexuality in order to praise or denounce their subjects, it is worth comparing different representations of Anne Boleyn. The process of constructing the mother of Elizabeth as a modest virgin is evident in Shakespeare's nostalgic All is True. Although compassion is demonstrated toward Katherine-for example Norfolk compares her to a jewel and underlines her loyalty (Shakespeare 1623, v1r; 2.2.30-36) and Henry speaks approvingly of her in the trial scene (Shakespeare 1623, v2r-v3r; 2.4)-emphasis is placed upon the physical beauty and moral goodness of Anne throughout the play. In the conversation between Anne and the Old Lady, strategically positioned before Katherine's trial scene, Anne is sympathetic to Katherine's plight. When the Lord 
Chamberlain inquires about the content of their private conversation Anne replies: "My good Lord, / Not your demand; it values not your asking: / Our mistris Sorrowes we were pittying", to which he replies "It was a gentle businesse, and becomming / The action of good women, there is hope / All will be well" (Shakespeare 1623, v2r; 2.3.51-56). Shakespeare's depiction of Anne's compassion for the queen is in stark contrast to Sander's report of her behaviour upon hearing of Catherine's death:

instead of putting on mourning on the day of Catherine's funeral, [Anne] put on a yellow dress; and on being congratulated on the removal of her rival, replied, 'No, I am sorry, not indeed because she is dead, but because her death has been so honourable'. (Sander 1877, 131-32)

Although Sander claims that Anne's sexual liaison with the king brought her promotion, Shakespeare presents an entirely different picture. In All is True, Anne is told by the Lord Chamberlain that it is her virtue that has brought reward:

You beare a gentle minde, \& heau'nly blessings

Follow such Creatures. That you may, faire Lady

Perceiue I speake sincerely, and high notes

Tane of your many vertues; the Kings Maiesty

Commends his good opinion of you, to you; and

Doe's purpose honour to you no lesse flowing,

Then Marchionesse of Pembrooke; to which Title,

A Thousand pound a yeare, Annuall support,

Out of his Grace, he addes.

(Shakespeare 1623, v2r; 2.3.57-65)

While Catholic propagandists such as Sander insisted that Anne was malicious and unchaste, Shakespeare's Anne is a modest, religious, and loyal subject:

An[ne]. I doe not know

What kinde of obedience, I should tender;

More than my All, is Nothing: Nor my Prayers

Are not words duely hallowed; nor my Wishes

More worth, then empty vanities: yet Prayers \& Wishes

Are all I can returne. Beseech your Lordship,

Vouchsafe to speake my thankes, and my obedience,

As from a blushing Handmaid, to his Highnesse;

Whose health and Royalty I pray for.

(Shakespeare 1623, v2r; 2.3.65-73)

Anne's reply alludes to that made by the Virgin Mary to the Angel Gabriel at the Annunciation: "Beholde, the seruant of the Lord: be it vnto me according to thy worde" (Luke 1:38), an episode that glorifies Mary as the obedient and humble mother of God. ${ }^{48}$ At the conclusion of his meeting with Anne, the Lord Chamberlain predicts that she will be the future mother of the Virgin Queen:

I haue perus'd her well,

Beauty and Honour in her are so mingled,

That they haue caught the King: and who knowes yet 
But from this Lady may proceed a lemme,

To lighten all this lle.

(Shakespeare 1623, v2r; 2.3.75-79)

In this period both Elizabeth and her father were compared with Christ. As Helen Hackett notes, E.K.'s gloss on the April Eclogue of the Shepheardes Calender shows that Elizabeth is "allegorically represented as fathered by Christ, or the Christian God" and the conception of Elizabeth resembles that of Christ himself (Hackett 1995, 109). ${ }^{49}$ The Petrarchan tradition of female value and beauty described in terms of precious stones is utilized for the unborn Elizabeth just at it is part of the iconography that surrounds her as queen. Anne's physical appearance was a target for Catholic propagandists like Sander because they could comment upon what was supposedly an outward manifestation of her inner corruption. Sander describes Anne as being:

rather tall of stature, with black hair, and an oval face of a sallow complexion, as if troubled with jaundice. She had a projecting tooth under the upper lip, and on her right hand six fingers. There was a large wen under her chin, and therefore to hide its ugliness she wore a high dress covering her throat. (Sander 1877, 25)

As Hackett points out $(1995,130)$, Sander implies that any little beauty Anne may have had was merely a witch-like beauty with charms to attract men: "She was handsome to look at, with a pretty mouth, amusing in her ways, playing well on the lute, and was a good dancer" (Sander 1877, 25). Although the above statements on her beauty are apparently contradictory, Sander leaves us in no doubt as to his consideration of her moral state: "But as to the disposition of her mind, she was full of pride, ambition, envy, and impurity" (Sander 1877, 25). In All is True, after Henry has married Anne, Suffolk commends her beauty and, like the Lord Chamberlain before him, prophesies the birth of Elizabeth:

She is a gallant Creature, and compleate In minde and feature. I persvade me, from her Will fall some blessing to this Land, Which shall In it be memoriz'd.

(Shakespeare 1623, v4v; 3.2.49-52)

The reference to Anne as "compleate / In minde and feature" indicates that the authors were aware of stories about Anne's physical deformities and sexual promiscuity. Again there is an emphasis on Anne's beauty, which is indicative of her moral goodness, and the blessed nature of the conception and birth of her child. Even her enemy Wolsey acknowledges her goodness:

What though I know her vertuous And well deseruing? yet I know her for A spleeny Lutheran, and not wholsome to Our cause, that she should lye i'th'bosome of Our hard rul'd King. (Shakespeare 1623, v4v; 3.2.98-102)

The description of Anne's coronation procession is in keeping with the way she is depicted throughout the play. A gentleman who is present at the procession speaks 
in praise of Anne and his tribute to her includes for the first time in the play a fusion of Petrarchan hyperbole and the woman-as-land trope:

Thou hast the sweetest face I euer look'd on.

Sir, as I haue a Soul, she is an Angell;

Our King ha's all the Indies in his Armes,

And more, and richer, when he straines that Lady,

I cannot blame his Conscience. (Shakespeare 1623, v6v; 4.1.43-47) ${ }^{50}$

When the Second Gentleman describes the scene of Anne's coronation to two other gentlemen he refers to "The beauty of her person" and exclaims that she is also morally beautiful, that is, virtuous: "Beleeue me Sir, she is the goodliest Woman I That euer lay by man" (Shakespeare 1623, v6v; 4.1.70-72). His description of her actions elevates her as a saint, but one who is politically astute and shows respect to the people:

At length, her Grace rose, and with modest paces

Came to the Altar, where she kneel'd, and Saint-like

Cast her faire eyes to Heauen, and pray'd deuoutly.

Then rose againe, and bow'd her to the people,

(Shakespeare 1623, v6v; 4.1.84-87)

The treatment of Anne in the above description prefigures that of Elizabeth in Cranmer's prophecy of the future queen's birth (Shakespeare 1623, x4r-x4v; 5.4.1462). Elizabeth's physical beauty is not explicitly described but is implied in Cranmer's emphasis on the "wisdom and fair virtue" of Elizabeth's "pure soul"

(Shakespeare 1623, x4r; 5.4.24-25). Elizabeth is a saint-like figure who will be counselled by "Holy and Heauenly thoughts" (Shakespeare 1623, x4v; 5.4.29) and a link is made between Elizabeth and the truth of the Reformed church for "Truth shall Nurse her" (Shakespeare 1623, x4r; 5.4.28). While Anne is compared to a remote and colonized land, "all the Indies", Elizabeth is directly linked with England:

This Royall Infant, Heauen still moue about her;

Though in her Cradle; yet now promises

Vpon this Land a thousand thousand Blessings,

Which Time shall bring to ripenesse.

(Shakespeare 1623, x4r; 5.4.17-20)

While Anne is described in terms of passive beauty and goodness, Elizabeth will act to bring about an English Utopia:

In her dayes, Euery Man shall eate in safety, Vnder his owne Vine what he plants; and sing The merry Songs of Peace to all his Neighbours.

(Shakespeare 1623, x4v; 5.4.33-35)

Her reign will be one of "Peace, Plenty, Loue, Truth, Terror" (Shakespeare 1623, $x 4 \mathrm{v} ; 5.4 .47)$ and the Virgin Queen will be sadly missed after her death: "A most vnspotted Lilly shall she passe / To th'ground, and all the World shall mourne her" (Shakespeare 1623, x4v; 5.4.61-62). 
Both The Faerie Queene and All is True utilize the metaphor of beauty as part of a political agenda to celebrate Protestant monarchs. The physical beauty of Elizabeth and her mother is a manifestation of their moral virtue and the hyperbolic descriptions of both women answers their demonization by Catholic propagandists such as Sander. These politically biased historical portraits use sexuality in order to praise their subjects just as Sander used sexuality to denounce his. Stories of the promiscuity of Anne Boleyn, like that promulgated by Sander, are implicitly challenged via her deification by Spenser and Shakespeare which also function as defences of Elizabeth. Anne is praised, or reviled, by reference to her sexual behaviour.

A similar process is evident in the depiction of Joan La Pucelle in Shakespeare's 1 Henry 6. Joan's characterization, which follows the chronicles, is built upon the ironic juxtaposition of Joan as saint and Joan as whore. This is particularly evident in her title of 'La Pucelle' which, as Norman Sanders points out in his edition of the play, connotes both 'Pucelle' (virgin) and 'pussel' (harlot) (Shakespeare 1981, 25-26). ${ }^{51}$ Like Anne, Joan's chastity or promiscuity is dependent upon the political and religious allegiance of her interpreters. In his depiction of Anne Boleyn as a whore Sander was keen to relate that she was known in the French court as 'the English Mare' (Sander 1877, 25), an epithet which he utilizes to imply a link between Protestantism and sexual promiscuity.

When Joan is introduced to the Dauphin Charles by the Bastard of Orléans she presents herself as base-born:

Dolphin, I am by birth a Shepheards Daughter, My wit vntrayn'd in any kind of Art: Heauen and our Lady gracious hath it pleas'd To shine on my contemptible estate. (Shakespeare 1623, k3v; 1.3.51-54)

but this statement contradicts her later denial of lowly origins when she is 'revealed' as a witch:

Decrepit Miser, base ignoble Wretch

I am descended of a gentler blood.

Thou art no Father, nor no Friend of mine.

(Shakespeare 1623, m1r; 5.6.7-9)

Similarly, Joan's report of the appearance of the Virgin Mary "in a Vision full of maiestie" (Shakespeare 1623, k3v; 1.3.58) contrasts starkly with her later conjuration of fiends (Shakespeare 1623, 16r; 5.3). At the beginning of the play Joan is presented as a brave and powerful martial maid and there are only hints of her degeneracyfor example when Charles becomes amorous she implies that she will yield after she has defeated her enemies (Shakespeare 1623, k3v; 1.3.86-95). When Joan proves her strength to Charles the Dauphin he proclaims "Stay, stay thy hands, thou art an Amazon, / And fightest with the sword of Debora" (Shakespeare 1623, k3v; 1.3.8384). Like the biblical Deborah, prophetess and Judge of Israel (Judges 4:4), she is blessed but comparison to the Amazon in the early modern period could be pejorative and is perhaps an indication of her true nature. ${ }^{52}$ 
Joan's beauty is associated with her Catholicism and, as with Duessa in The Faerie Queene, a false exterior hides a morally corrupt interior. The notion of Catholic illusion is evoked when Joan tells Charles the Dauphin that she has been made beautiful by the Virgin Mary who appeared to her in a vision: "And whereas I was black and swart before, / With those cleare Rayes, which shee infus'd on me, I That beautie am I blest with, which you may see" (Shakespeare 1623, k3v; 1.3.6365). Furthermore, Charles's worship of Joan alludes to Catholic veneration of icons: "Bright starre of Venus, falne downe on the Earth, I How may I reuerently worship thee enough?" (Shakespeare 1623, k3v; 1.3.123-124). The brightness of Joan's changed countenance masks a "black and swart" reality, the absence of light in her physical beauty suggesting more sinister undercurrents.

Throughout the play, French comments upon Joan's goodness are constantly undercut by English insults and bawdy insinuations. In all his references to Joan, Talbot denounces her as both a witch and a strumpet. As with Duessa and Acrasia, witchcraft and sexual promiscuity are interrelated and denouncing the enemy for practising both is an effective way to undermine the political, religious and ethnic Other who is also the Sexual Other. Talbot's first reference to Joan is his use of the Pucelle/pussel pun in the scene discussed above: "Frenchmen, Ile be a Salisbury to you. I Puzel or Pussel, Dolphin or Dog-fish, / Your hearts lle stampe out with my Horses heeles, I And make a Quagmire of your mingled braines" (Shakespeare 1623, k4v; 1.6.84-87). Similarly when Talbot and the other English soldiers discuss Joan they doubt that such a warlike maid could be a virgin:

Bur[gundy]. But what's that Puzell whom they tearme so pure?

Tal[bot]. A Maid, they say.

Bed[ford]. A Maid? And be so martiall?

Bur[gundy]. Pray God she proue not masculine ere long:

If vnderneath the Standard of the French

She carry Armour, as she hath begun.

(Shakespeare 1623, k5r; 2.1.20-24)

As we saw with the reference to Joan as an Amazon, there is ambivalence about female military might. If Joan is a witch and a whore then the French fight with the support of the devil whereas Talbot believes that the English have God on their side: "Well, let them practise and conuerse with spirits. / God is our Fortresse, in whose conquering name / Let vs resolue to scale their flinty bulwarkes" (Shakespeare 1623, $\mathrm{k} 5 \mathrm{r} ;$ 2.1.25-27). Similarly in the "Supplication" the author, speaking with the collective voice of the New English Protestants in Ireland, claims God is on their side against the Irish rebels. In contrast to Talbot's denunciation of Joan as a witch and whore, Charles praises her as divine when she succeeds in the rescue of Orléans from the English:

Diuinest Creature, Astrea's Daughter, How shall I honour thee for this successe?

Thy promises are like Adonis garden, That one day bloom'd, and fruitfull were the next. France, triumph in thy glorious Prophetesse, Recouer'd is the Towne of Orleance. 
More blessed hap did ne'er befall our State.

(Shakespeare 1623, k5r; 2.1.4-10)

Allusion to Elizabeth is again evident by reference to Astraea, the just virgin of the golden age, who was often identified with the queen. ${ }^{53}$ Towards the climax of the play Talbot and the other English become more vitriolic in their verbal attacks on Joan, which are shown to be justified when she conjures fiends of the devil (Shakespeare 1623, I6r; 5.3). The same is true of her trial scene where her claim to be pregnant and the references to her many lovers prove her a whore and her curse proves her a witch (Shakespeare 1623, m1r; 5.6.59-91).

The driving force behind 1 Henry 6 as a work of English protestant propaganda is its attack on Joan's claim to virginity and piety. The French are undermined by her promiscuity and witchcraft which is not only alleged by the English but, toward the end of the play, is shown to be true. Like Spenser's depiction of the enemies of Elizabeth, the play functions as an attack upon the political and religious Other via the sexual Other. The depiction of Joan La Pucelle in 1 Henry 6 can illuminate the reading of other gendered histories like that of Anne Boleyn. The writings of Sander, Spenser, and Shakespeare on Anne Boleyn and Elizabeth are histories that reveal the politicizing of women's sexuality. Women's bodies are used as metaphors whereby female chastity and beauty is indicative of political and religious righteousness and female sexual promiscuity signals political and religious corruption. Female chastity or sexual promiscuity is treated as a public issue and, as these histories show, propaganda is written on the bodies of women.

\section{Chapter 5}

Savage Landscapes: Ireland and the Irish Rebels 
In Book 2 of The Faerie Queene Guyon reads from "An auncient booke, hight Briton moniments" (2.9.59.6) a chronicle of Briton Kings from the Trojan Brutus to Uther Pentragon, his father. In this account, royal claims to savage lands are justified by reference to the civilizing influence of Brutus on ancient Britain. Before the coming of Brutus the land was a "saluage wildernesse, Vnpeopled, vnmanurd, vnprou'd, vnpraysd" (2.10.5.3-4). Its few inhabitants were barbaric and lived deep in the interior:

But farre in land a saluage nation dwelt, Of hideous Giants, and halfe beastly men, That neuer tasted grace, nor goodnesse felt, But like wild beasts lurking in loathsome den, And flying fast as Roebucke through the fen, All naked without shame, or care of cold, By hunting and by spoiling liued then; Of stature huge, and eke of courage bold, That sonnes of men amazd their sternnesse to behold. (2.10.7.1-9)

Whilst the reference to "hideous Giants, and halfe beastly men" suggests the kind of fantastic reports evident in travel literature, ${ }^{54}$ Spenser's description of the inhabitants of early Britain also bears resemblance to contemporary descriptions of Ireland and the Irish.

The "saluage nation" of ancient Britain lived "farre in land" a description evoking the early modern Irish interior much of which was off limits for the representatives of Elizabeth's government and so prone to the kind of imaginings other unexplored countries provoked. It is significant that, whilst Elizabeth's ancestry is carefully traced, the origin of Britain's early savages is not known "But whence they sprong, or how they were begot, / Vneath is to assure" (2.10.8.1-2). The narrator asserts Brutus's right to establish the Britons in England by declaring the injustice of the savages' reign, claiming that the land itself suffered from and resented their immorality:

They held this land, and with their filthinesse Polluted this same gentle soyle long time:

That their owne mother loathd their beastlinesse, And gan abhorre her broods vnkindly crime, All were they borne of her owne natiue slime, $(2.10 .9 .1-5)^{55}$

Brutus's claim is justified primarily because he is "From royall stock", which makes him socially as well as morally superior to the savages who inhabit the land. The claim of Una and her parents in Book 1 to the territories held by the dragon are similarly justified by royal blood (1.1.5.3-5). If Una is a representative of Elizabeth, as argued in chapter 2 of this book, then the claim made to savage lands extends to Ireland. Because Brutus is royal the prior claim of the native population is disregarded by the narrator. Further justification for Elizabeth's rule in Ireland is made when the chronicle refers to the reign of Gurgunt and the asylum he provided for Spanish refugees: 
He also gaue to fugitiues of Spayne,

Whom he at sea found wandring from ther wayes,

A seate in Ireland safely to remayne,

Which they should hold of him, as subiect to Britayne.

(2.10.41.6-9)

As Kitchin points out in his nineteenth-century edition of Book 2, "This is a manifesto to shew the right of England over Ireland in the days of Queen Elizabeth, and to justify her severe measures, in which Spenser had necessarily taken some part" (Spenser 1910, 228n41.6). A declaration of the right of Elizabeth's claim to Ireland is also made in Spenser's A Brief Note of Ireland where the address 'To the Queene' refers to Ireland as "your owne iuste and heritable dominion" (Spenser 1949, 236 line 32).

Like the interior of ancient Britain before the civilizing influence of Brutus, much of the landscape of The Faerie Queene is unpredictable and harbours threatening figures who are ever ready to attack the good Protestant knight and his lady. Whilst woodland could be a hostile environment in the literary traditions which informed Spenser's writing, ${ }^{56}$ he was also presumably inspired by his experiences in Munster where woodland provided protection for the Irish rebel and so presented a logistical nightmare to the New English colonist.

According to Eileen McCracken perhaps one-eighth of Ireland was woodland at the end of the sixteenth century but by 1700 most of this had been destroyed (McCracken 1959, 273; 296). The wood was valuable for construction, tanning leather, shipbuilding, pipe and barrel-stave making, and iron smelting. Spenser would have been well aware of the economic potential of the woodland, obviously a primary consideration for the colonists. In his survey of the land and people of Ireland, R. A. Butlin points to extensive cutting, processing and exportation of timber, especially in Munster (Butlin 1976, 165). Yet woodland was also a threat to the colonizers as well as a profitable raw material because in many parts of Ireland it made an area dangerous or even inaccessible. This was particularly true of northern Ireland where impenetrable woodland and bogs acted as safe territories for the Irish but were dangerous areas for the English. As McCracken states, the features of the Irish landscape "had been a serious obstacle to the Tudor conquest and colonization of Ireland. The Irish had resisted the invaders from the shelter of the bogs and the woods whenever possible" (McCracken 1959, 287). Butlin agrees that the woods were literally a site of resistance for the Irish and hostile, unknown areas for the English colonialist: "Inland, there can have been very few roads, and journeys on horseback through the 'straits', passes, and fastnesses were fraught with dangers, both from the enemy and from the elements" (Butlin 1976, 162).

Comments on the impassability of the Irish landscape, because of geographical impediments and dangerous inhabitants, are common in English colonial writings on Ireland. Thomas Gainsford says of Munster: "The grounds adiacent are very fertile ... but more inward they are very barren and mountanous, full of boggs, wood, and other remote places, whose fastnes hath incited the people to ouer-great presumption" (Gainsford 1618, 145). A sense that the landscape colludes with the rebels is evident in Thomas Blenerhasset's comment that "there be two, the chief supporters of al their insolencie, the inaccessable woods, \& the not passible bogs" 
(Blenerhasset 1610, B1r). Similarly Gainsford remarks that "[Ireland is] diuided into such fastnes of mountaine, bogg, and wood, that it hath emboldned the inhabitants to presume on hereditary securirie [sic], as if disobedience had a protection" (Gainsford 1618, 144). The Irish landscape familiar to Spenser is similar to that of The Faerie Queene in many of its features. Arnold Williams' description of Spenser's Fairyland as "rough and dangerous country, unprovided with signposts and road maps" also accurately describes the early modern Irish interior (Williams 1967, 48).

Butlin points out that anxiety about the dangers which lay within the woodland led to inaccuracy about the extent of its coverage. He claims that much of the evidence for the geographical character of Ireland at this time is from the observations of English visitors who were unlikely to be objective. Assessments of geography and climate tended to relate to the conduct of military campaigns: "Woods, bog, and mountain 'fastnesses' were seen by the military as extensive havens of refuge for outlaws and rebels, and accounts of their size were thus prone to exaggeration and contradiction" (Butlin 1976, 142-3). As a consequence, "political decisions were often made on the basis of incomplete or fictitious or mythical notions of geography" (Butlin 1976, 142). Spenser's Fairyland, a fictious and mythical landscape which harbours all kinds of monsters, is perhaps not so far removed from those parts of early modern Ireland that presented such a challenge to the English colonists. The natural landscape of Ireland, with its dense and extensive woodlands and bogs, is evoked throughout the poem, for example in the story of the journey undertaken by Florimell who flees from her pursuers:

So long she trauelled, till at length she came

To an hilles side, which did to her bewray

A little valley, subiect to the same,

All coured with thick woods, that quite it ouercame.

(3.7.4.6-9)

The description of the witch's cottage which Florimell discovers located deep in the woods is similar to cottages throughout contemporary rural Ireland: "There in a gloomy glen she found / A little cottage built of stickes and reedes / In homely wize, and wald with sods around" (3.7.6.1-3). In Ireland, stone was rarely used in the construction of rural dwellings; typically timber, clay, turf sods, and tree boughs were used for the structure which was then covered with turf, straw, and wattles. The roofs were usually thatched though there were also English-style cottages which had tiled gable roofs (Butlin 1976, 157).

Pauline Henley claimed that Spenser's imagination was fired by the beauty of the Irish landscape and she also perceived Irish influence in his depiction of Acrasia's Bower. She considered it possible that Spenser was thinking of the lakes of Killarney, known in the sixteenth century as Lough Lene (Henley 1928, 117). That a poet would use the landscape around him as a source of inspiration is very likely. In the View Irenius reports on the physical beauty of Ireland and its economic usefulness:

... it is a moste bewtifull and swete Countrie as anye is vnder heaven . . . adorned with goodly woodes fitt for buildinge of howsses and shipps . . . Allsoe full of verye good portes and havens openinge vppon Englande and Skotlande as invitinge vs to 
Come vnto them to see what excellente Commodities that Countrye Cane afforde ... (Spenser 1949, 62)

Yet this comment on the beauty of the Irish landscape exists alongside reports of its hostility and inaccessibility, for Irenius claims it is a land full of dense "wodes" and "perillous places" where travellers have been "Robbed and sometimes murdered" (Spenser 1949, 224). The Bower of Bliss, like the Irish landscape, is beautiful but also treacherous. As Stephen Greenblatt points out, the bower must be destroyed because it is a threat to civility (Greenblatt 1980, 173). Similarly Ireland's woods must be destroyed not only because the wood is valuable but because the woodland presents a danger to the colonists. When Amavia tells Guyon her story she refers to the land where Acrasia dwells:

Within a wandring Island, that doth ronne And stray in perilous gulfe, her dwelling is; Faire Sir, if euer there ye trauell, shonne The cursed land where many wend amis, And know it by the name; it hight the Bowre of blis. $(2.1 .51 .5-9)$

The notion of Ireland as a cursed land is expressed throughout the "Supplication" and by Irenius in the View:

they saie yt is the fatall destinie of that Lande that no purposes whatsoeuer are mente for her good, will, prosper or take good effecte, which wheather it proceed from the very Genius of the soile, or influence of the starres. . . it is harde to be knowen but yeat muche to be feared (Spenser 1949, 43-44)

The Bower of Bliss is so called because of its beauty and sensory pleasures but it is also dangerous because of the presence of Acrasia. Similarly parts of Ireland were dangerous because they were inhabited by the Native Irish rebels.

Gainsford announces that although "The countrey is very fruitfull and pleasant, not so mountanous" it is "ill inhabited" (Gainsford 1618, 145). Like the Irish rebels who take full advantage of the landscape which impedes the enemy, Acrasia can also manipulate nature. The journey to the Bower of Bliss is full of physical dangers which the Palmer recognizes are the work of "that same wicked witch, to worke vs dreed, I And draw from on this iourney to proceede" (2.12.26.4-5). Guyon and the Palmer encounter such impediments as the Gulf of Greediness, the Rock of Reproach, the Wandring Islands, the quicksand of Unthriftyhead, and the Whirlpool of Decay (2.12.1-21) all based, as Upton noted, on similar phenomena in the twelfth book of Homer's Odyssey (Upton 1987a, 594). Perhaps the most dangerous of these are the Wandring Islands because of their deceptive nature which the Ferryman outlines to Guyon and the Palmer:

Yet well they seeme to him, that farre doth vew, Both faire and fruitfull, and the ground dispred With grassie greene of delectable hew, And the tall trees with leaues apparelled, Are deckt with blossomes dyde in white and red, That mote the passengers thereto allure; 
But whosoeuer once hath fastened

His foot thereon, may neuer it recure,

But wandreth euer more vncertein and vnsure.

$(2.12 .12 .1-9)$

The physical beauty of the Wandring Islands is illusory, and there is a danger that any good Protestant knight setting foot on the island will suffer a crisis of faith, will become "vncertein and vnsure". The implication is that the land is dangerous because it is strange, unknown, and unmapped. David J. Baker, writing about the cartography of early modern Ireland, points out that the English did not have cartographic control because in this period "A complete and detailed representation of Ireland did not exist" (Baker 1993, 82). In the early modern period maps of Ireland by royal cartographers "were often conjectural and muddled" (Baker 1993, 78). In other words, like the travellers who explore the Wandring Islands, the English colonists also felt "vncertein and vnsure". Baker further considers "what happens to the conceptual topography of colonial power when, quite literally, it can no longer locate itself on the map" (Baker 1993, 77). ${ }^{57}$ Butlin comments on how Ireland's unmapped state affected its governance:

In spite of the increase in surveying and cartography in the late sixteenth century, the English administrators still lacked the detailed geographical data necessary for a rational administrative framework, and thus relying on an imperfect perception of the geography of Ireland failed to achieve their objectives. (Butlin 1976, 167)

Being vulnerable to misdirection and getting lost in an unknown land was a problem for the officials who tried to impose order in Ireland. Baker outlines an incident in the career of Henry Sidney as Lord Deputy when he pursued the rebel sons of the Earl of Clanrickarde in August 1576. Sidney scoured the country in an attempt to track them down but they continued to elude him and Baker concludes:

... the Irishmen he seeks are always elsewhere when the Lord Deputy approaches. Their reluctance to be exactly where the English 'Intelligence' network had put them introduces a randomness into his planned manoeuvres, and disperse both his march and his writing into multiple sorties, feints, and untracked wanderings. (Baker 1993, 85)

The fear that Guyon will become "vncertein and vnsure" if he ventures onto one of the Wandring Islands suggests Spenser's anxiety that the English have lost their way, politically as well as geographically, in the colony.

When Guyon and the Palmer are getting close to the Bower of Bliss Acrasia raises a fog in an attempt to prevent them from reaching her land:

[they] shortly gan descry

The land, to which their course they leueled;

When suddeinly a grosse fog ouer spred

With his dull vapour all that desert has,

And heauens chearefull face enueloped,

That all things one, and one as nothing was, 
And this great Vniuerse seemd one confused mas.

(2.12.34.3-9)

This recalls the "foggy mist" raised by the witch Duessa in the Fradubio episode (1.2.38) and the "darkesome clowd" employed by her against Redcrosse in his battle with Sansloy (1.5.13). Traditionally it was thought that witches could conjure mists but the appearance of the fog carries a more precise geographical allusion. Thomas Gainsford referred to the frequent mists in Ireland: "The continuall showers and mists make the countrey more dangerous to our Nation, debaring the absolute assurance of wholesome aire, and the consequent health" (Gainsford 1618, 148). Although Gainsford here comments on climate, his assertion carries with it a suggestion of spiritual danger. According to Douglas D. Waters "It was commonplace to call the blinding result of Roman false teaching, including the Mass, a 'mist'" and he gives examples from the writings of John Jewel and Richard Hooker to support his claim that the mist conjured by Duessa "may symbolize, in the theological or anagogical allegory, the confusing and blinding influence 'the falsehood of the pope's mass' was thought to have upon the Protestant mind" (Waters 1970,46$).{ }^{58}$ In the fog raised by Acrasia lies the danger of the good Protestant being blinded and confused:

Thereat they greatly were dismayd, ne wist How to direct their way in darkenesse wide, But feard to wander in that wastfull mist, For tombling into mischiefe vnespide. Worse is the daunger hidden, then descride. $(2.12 .35 .1-5)$

Aside from the practical consideration of guerrilla warfare which allows the rebels to remain a hidden danger, the darkness recalls the gloom of Error's cave in Book 1 and the reference to wandering the location of her cave in the Wandring wood. 'Wandering' is used with the same intimation as throughout the poem, that is, to deviate morally and spiritually. Anxiety about the danger that lies hidden within an attractive landscape is linked to anxiety about attractive women like Duessa whose beauty conceals a degenerate interior.

The savages captained by Maleger who lay seige to Alma's castle come from a hostile landscape in order to attack the symbol of temperance:

A thousand villeins round about them swarmd

Out of the rockes and caues adioyning nye,

Vile caytiue wretches, ragged, rude, deformd,

All threatning death, all in straunge manner armd,

Some with vnweldy clubs, some with long speares,

Some rusty kniues, some staues in fire warmd.

Sterne was their looke, like wild amazed steares,

Staring with hollow eyes, and stiffe vpstanding heares.

$(2.9 .13 .2-9)$

Hankins draws attention to the classical association between caves and woodland: "Since the deep cave or spelunca alta of Virgil is part of the forest silva and shares 
its associations with the formlessness of primordial matter, the cave suggests the absence of light, the presence of spiritual darkness, the 'abyss' of Chaos, and the descent to hell" (Hankins 1971, 74). Great emphasis is placed on the demonic appearance and aggression of the villains who attack Alma's castle. They are referred to as fly-like, swarming around Guyon and Arthur (2.9.13.2) and aggravating the two knights "As when a swarme of Gnats at euentide / Out of the fennes of Allan do arise" (2.9.16.1-2), a description explicitly linking them with the Irish by reference to the bog-land of central Ireland. ${ }^{59}$ The reference to the rebellious mob as "Vile caytiue wretches" echoes the description of the rebellious Irish in A Brief Note where they are referred to as "vile Catifes" unworthy of Elizabeth's clemency (Spenser 1949, 241). The word 'vile' is used repeatedly to describe Acrasia.

Before they attack Arthur the "twelue troupes" that are led by Maleger "reard a most outrageous dreadfull yelling cry" (2.11.17.9). In the View Irenius tells Eudoxus about Irish war cries:

the nexte that I haue to treate of is theire manner of the raisinge there crye in theire conflictes and at other troblesome times of vprore The which is verye naturall Scythyan as ye haue red in Diodorus Siculus and in Heroditus . . . (Spenser 1949, 103).

The words chosen for the battle cry are important:

at theire ioyninge of Battell they likewise Call vppon theire Captaines name or the worde of his Auncestors As they vnder Oneale crye Landargabo, that is the bloddie hande which is Oneles badge . . . And to theire ensample the olde Englishe allsoe which theare remaynethe haue gotten vp theire cryes Scithyanlike, as Cromabo and Butlerabo (Spenser 1949, 103)

Using natural imagery with strong biblical overtones (for example see Genesis 7:624) Maleger's mob is compared to destructive water which floods, and so ruins, the land:

And therewith all attonce at him let fly

Their fluttring arrowes, thicke as flakes of snow,

And round about him flocke impetuously,

Like a great water flood, that tombling low

From the high mountaines, threats to ouerflow

With suddein fury all the fertile plaine,

And the sad husbandmans long hope doth throw

A downe the streame, and all his vowes make vaine,

Nor bounds nor banks his headlong ruine may sustaine.

(2.11.18.1-9)

This metaphor utilizes the trope of colonizer as husbandman and manager of the "fertile plaine", that is, the Irish soil. The implication here is that Arthur as "the sad husbandman" is in danger of ruin by the Irish who are figured as a devastating uncontrollable force of nature. As a good Protestant Arthur will carefully cultivate the 
land which, if left to the rebels, will be destroyed. Like Talus with his flail, Arthur "with his sword disperst the raskall flockes" (2.11.19.2).

The references to the natural world continue when Maleger's men are referred to as weeds crushed by Arthur's horse: "And vnder neath him his courageous steed, I The fierce Spumador trode them downe like docks" (2.11.19.6-7). In Book 4 Ate, the malevolent companion of Duessa, stirs up contention by the deliberate sowing of weeds:

Such was her house within; but all without, The barren ground was full of wicked weedes, Which she her selfe had sowen all about, Now growen great, at first of little seedes, The seedes of euill wordes, and factious deedes; Which when to ripenesse due they growen arre, Bring foorth an infinite increase, that breedes Tumultuous trouble and contentious iarre, The which most often end in bloudshed and in warre. (4.1.25.1-9)

As in the "Supplication" the metaphor of the weed is utilized to evoke dissension and, given the relationship between Ate and Duessa, Roman Catholic sedition is implied. Ate is a threat to good plants and planters with her malevolent scattering of weeds, a corruption which is an inversion of the good husbandry and cultivation encouraged by T. C. in the "Supplication" and by Irenius in the View. Just as Ireland is depicted as an inversion of England as a good mother figure in the "Supplication" so Ate is a monstrous mother who nurtures rebellion. Like the witch who creates the False Florimell in Book 3 of The Faerie Queene her actions parody the divinely sanctioned human act of procreation and the notion of a good fertile mother for she sows her rancorous seeds alone and on barren ground.

The appearance of the mob that attacks Arthur prefigures the men transformed by Acrasia in the Bower of Bliss:

The first troupe was a monstrous rablement Of fowle misshapen wights, of which some were Headed like Owles, with beckes vncomely bent, Others like Dogs, others like Gryphons dreare, And some had wings, and some had clawes to teare, And euery one of them had Lynces eyes, And euery one did bow and arrowes beare: All those were lawlesse lustes, corrupt enuies, And couetous aspectes, all cruell enimies. (2.11.8.1-9)

As with Error and Duessa, a monstrous appearance is a manifestation of moral degeneracy. In A Brief Note the distinction between human and animal life is blurred in the call for Elizabeth to take severe action against Irish rebellion and so give succour to the New English Planters: "[we] haue nowe nothing left but to cry vnto you for tymelie aide before we be brought to vtter distruction and our wreched liues 
(which onelie now remaine vnto vs be made the pray of dogges and sauage wilde beastes ..." (Spenser 1949, 241, lines 219-223). It is left unclear, perhaps deliberately, whether the "sauage wilde beastes" are wolves and other animal inhabitants of the Irish interior or the Native Irish rebels who dwell therein.

In Book 3 Florimell rushes out of the wood and is pursued: "Lo where a griesly Foster forth did rush, Breathing out beastly lust her to defile" (3.1.17.2-3). As we saw in previous chapters, the Catholic Irish, closely identified with the woodlands of Ireland, were often accused of being licentious. Consequently, it might be that Florimell, under threat of violence from a savage woodland dweller, is a representative of the New English who feared just such an attack. By making the forester signify lust Spenser here, as elsewhere in The Faerie Queene, represents a political enemy as sexually degenerate. Usually in the poem the sexually degenerate figure is female but enemies of either sex display a voracious sexual appetite.

It is ironic that the would-be rapist chasing Florimell is so closely associated with the woodland in which he lives since the policy of destruction initiated by the New English colonist was effectively an economic rape of the Irish landscape. Here colonial reality is inverted and individualization in the allegory is utilized in order to avoid the real socio-political context. The forester's lustful desire to rape is said to be animal-like, his lust is "beastly" and in this way he is identified with the wolves which, along with the resistant Irish, occupied the woods and plagued the English invaders. As McCracken points out, Blenerhasset described the woodkern, "other suspitious Irish", and the wolf as the most serious dangers confronting British settlers in Ireland (McCracken 1959, 288). ${ }^{60}$ Gainsford claimed that thieves and "the abundance of wolues" forced the Irish "to house their cattle in the bawnes of their Castles" (Gainsford 1618, 148).

Spenser would certainly have been familiar with the threats from rebels and wolves: McCracken claims that in the river Bride valley, twenty miles west of Cork, wolves were a constant annoyance at the time of the Civil Survey. Cromwell forbade the export of Irish wolfhounds in 1652 and in 1653 offered rewards of between 10 shillings and 6 pounds for every wolf killed, depending on its age and sex. In 1656 $£ 3,874$ was paid for the carcases. This slaughter policy and the destruction of the woodlands led to the eventual extinction of wolves around 1770, in England they had been killed off before 1500 (McCracken 1959, 288-89). For men like Spenser the close proximity of wolves and Irish in the woodlands doubtedless contributed to the identification of the Irish as bestial. In 'civilized' countries like England such savage creatures, wolves and wood-dwelling rebels, had long been extinct.

Gainsford claimed that the wars and savagery of the Irish not only resulted in disorder but so terrified the animals and birds of Meath that all the creatures were driven from the area (Gainsford 1618, 145). In this case the Irish are not simply identified as savage but are considered unnatural.

The forester manages to escape from Timias, who seeks to avenge the attempted rape of Florimell, using his "knowledge of those woods where he did dwell" (3.5.14.3). Similarly the Irish used their knowledge of the woodland to escape from or attack the advancing English who, although better organised and in greater numbers, were disadvantaged due to the circumstances of guerrilla warfare. Irish 
bogland, which often existed on the periphery of woodland, thwarted the success of the English military. As Butlin put it:

The widespread existence of both upland and lowland peat bogs is noted by contemporaries, especially in the context of military strategy, and a common complaint of English soldiers was that 'the woods and bogs are a great hindrance to us and help to the rebels', the latter being able, with only a handful of men, to engage in 'ambushcados' and, when necessary, escape with ease. (Butlin 1976, 145)

The Forester is joined by his two brothers and all three lie in wait to spring an attack upon Timias:

Within that wood there was a couert glade, Foreby a narrow foord, to them well knowne, Through which it was vneath for wight to wade; And now by fortune it was ouerflowne:

By that same way they knew the Squire vnknowne Mote algates passe; for thy themselues they set There in await, with thicke woods ouergrowne, And all the while their malice they did whet With cruell threats, his passage through the ford to let. (3.5.17.1-9)

The threat posed by savages who lurk in the woods ready to assault unsuspecting travellers is realized in the behaviour of the forester and his brothers toward Timias who attempts "through the ford to passen" but is prevented:

But that fierce foster, which late fled away, Stoutly forth stepping on the further shore, Him boldly bad his passage there to stay, Till he had made amends, and full restore For all the damage, which he had him doen afore (3.5.18.5-9)

Timias kills them all, having prevented the last surviving brother from retreating into the safety of the wood. Just as the actions of the forester and his brothers prefigure those of Pollente, who accosts travellers attempting to cross his bridge in Book 5 , so the account of the death of the last remaining brother is analagous to that of Pollente whose headless body, following decapitation by Artegall, is carried downstream by the river Lee $(5.2 .18-19)^{61}$

... Timias him lightly ouerhent, Right as he entring was into the flood, And strooke at him with force so violent, That headlesse him into the foord he sent: The carkas with the streame was carried downe, But th'head fell backeward on the Continent. $(3.5 .25 .2-7)$ 
The ambush of Timias by the forester and his brothers dramatizes a tangible danger to the New English in Ireland. Guerrilla warfare afforded the rebels a distinct advantage because they were unseen by their enemy and their actions could not be accurately anticipated. The Irish rebels could quickly appear out of the woods and bogs, attack their enemy, and then fade back into the landscape. In the View Irenius complains of the rebel's tactics: "he still flyethe from his foe and lurketh in the thicke woods and straighte passages, waytinge for Advantages . .." (Spenser 1949, 100-01). Gainsford similarly reveals a fear of ambush:

... the passages are euery way dangerous, both for vnfirmenes of ground, \& the lurking rebell, who will plash downe whole trees ouer the paces, and so intricately winde them, or lay them, that they shall be a strong barracado, and then lurke in ambush amongst the standing wood, playing vpon all commers, as they intend to goe along. (Gainsford 1618, 144)

That the Irish would use fallen trees as part of their defensive military stategy is commented upon in "A Booke of Questions and Answars Concerning the Warrs or Rebellions of the Kingdome of Ireland" where the military tactics of the Gaelic Irish are likened to those of "the valliantest nations" and particularly those of George Scanderbag, Prince of Epirus, against the Turks:

for he did destroy the wayes and passages, that the Turkes had into his Country, and plashed the woodes, and felled down the great trees cross the wayes, that ther could be no entry for the Turks, but such as he must hewe out onely with multitud of pioners; or all fight for yt to his great dammage, where Scanderbag for many yeres together with 12000 men, which was the greatest of his Army, did allwaies incounter with the Turkes huge \& great armyes, that were a hundred or two hundred thousand men, and still put him to the worst. The selfe same do the Irish in all ther warrs. (Morgan 1995, 94) ${ }^{62}$

The Irish "withdrawe themselues into the woodes, mountaines, boges and straights" not because of cowardice but in order to make the best use of their environment (Morgan 1995, 94). The advantage of surprise coupled with knowledge of the landscape meant that the rebels could attack a great number of English soldiers with fewer men and weapons than their enemy. This was recognised by Gainsford:

On the bogg they likewise presume with a naked celeritie to come as neere our foote and horse, as is possible, and then flie off againe, knowing we cannot, or indeed dare not follow them: and thus they serue vs in the narrow entrances into their glins, and stony paths, or if you will dangerous quagmires of their mountaines, where a 100 shot shall rebate the hasty approch of 500; and a few muskets (if they durst carry any) well placed, will stagger a pretty Armie, not acquainted with the terror, or vnpreuenting the mischeefe. (Gainsford 1618, 144)

The fusion of political rebellion and moral depravity is a recurrent motif in The Faerie Queene. The Forester represents the political enemy, the Native Irish rebel, but he is also sexually degenerate, suggested by his desire to rape and sexual disease as his punishment. He may have escaped from Timias but cannot dodge this penalty which constitutes divine retribution: 
... shortly he from daunger was releast, And out of sight escaped at the least; Yet not escaped from the dew reward Of his bad deeds, which dayly he increast, Ne ceased not, till him oppressed hard The heauy plague, that for such leachours is prepard. (3.5.14.4-9)

A. C. Hamilton annotates the 'heauy plague' which is his punishment as "possibly implying syphilis or leprosy" (Spenser 1977, 348). In an earlier note on Lecherie (1.4.26.9) he claims that "Leprosy was widely held to be transmitted venereally and to be a special punishment inflicted by God" (Spenser 1977, 69). As we saw in chapter 2 the notion of sexual disease as the penalty for moral depravity is also evident in the figure of Duessa whose beauty masks a rotten interior which suggests venereal disease. In this period Irish rebellion was often considered in terms of disease or infection. In the View Irenius refers to rebellion in Ireland as a contagion, the Irish nature as infectious, and Ireland as a sick body (Spenser 1949, 63; 119; 163). Similarly in A Brief Note of Ireland Elizabeth is informed that because members of her government conspired against Tyrone and because of divisions in the government the current situation has been brought

to that dangerous condicion that nowe they stand in. ffor from this head through tolleracion and too much temporizing the euill is spred into all partes of the Realme and growne in to so vniuersall a contagion that nothing but a moste violent medecyne will serue to recouer yt. (Spenser 1949, 238, lines 102-106)

In Barnaby Rich's The Anothomy of Ireland (1615), which like the View takes the form of a dialogue, Antodonus laments that "the dysceases of Irelande are many \& the sycknes is growne to that contagyon, that it is allmost past cure" (Hinton 1940, 83). Similarly Fynes Moryson uses the metaphor of infection for what he regards to be the ill effects of the Catholic Native Irish on the Old English, or "English Irish" as he calls them:

Touching the English Irish. . . . It is wonderfull yet most true, that for some later ages they haue beene (some in high some in lesse measure,) infected with the barbarous Customes of the meere Irish and with the Roman Religion so as they grewe not only as aduerse to the Reformation of Ciuill policye and religion, as the meere Irish but euen combyned with them, and shewed such malice to the English nation, as if they were ashamed to haue any Community with it, of Country, bloud, religion, language apparrell, or any such generall bond of amity. (Moryson 1903, 201-02)

Moryson also draws a connection between the Irish diet and a supposed lack of cleanliness which leads to contamination:

Many of the English-Irish, haue by little and little been infected with the Irish filthinesse, and that in the very cities, excepting Dublyn, and some of the better sort in Waterford, where the English continually lodging in their houses, they more retaine the English diet. (Moryson 1617, Sss2r) 
Maleger, the captain of the mob that lays seige to Alma's castle, is described as an horrific kind of walking corpse:

As pale and wan as ashes was his looke, His bodie leane and meagre as a rake, And skin all withered like a dryed rooke, Thereto as cold and drery as a Snake, That seem'd to tremble euermore, and quake:

All in a canuas thin he was bedight, And girded with a belt of twisted brake, Vpon his head he wore an Helmet light, Made of a dead mans skull, that seem'd a ghastly sight. (2.11.22.1-9)

Charles G. Osgood points out that although Maleger has been variously claimed to represent passions, sensuality, death, and deadly sin, the obvious etymological derivation is that Maleger means 'desperately sick', and perhaps 'sick unto death' (Osgood 1931, 504-06). M. M. Gray claims that in the depiction of the seige of Alma's castle Spenser was alluding to the Munster rebellion and the figure of Maleger is "perhaps in some particulars like the starving rebel leaders" (Gray 1930, 416). Gray further suggests that the resilience of Maleger, evident in the difficulty Arthur has in literally crushing his enemy, is a comment upon the resilience of the Irish rebels: "Just the same disconcerting vitality characterised rebellion in Ireland" (Gray 1930, 416).

The savage man in Book 4 continues the motif of salacious savages who inhabit the woodland and threaten to rape the ladies of good Protestant knights. ${ }^{63}$ The parallels between the stories of Serena and Amoret, both assaulted by savage cannibals, have been noted by Donald Cheney $(1966,108-09)$. There are also parallels between the twins Argante and Ollyphant in Book 3 and the savage man in Book 4, referred to in the argument as "greedie lust" (4.7.Argument.1). This monstrous figure appears to be a fusion of the sexually promiscuous degeneracy of the incestuous twins and the appetite for human flesh which is the main feature of the Saluage Nation (6.8.35-51).

Whilst her protector sleeps, Amoret "of nought affeard" wanders through the forest "for pleasure, or for need" (4.7.4.1-2) where she is abducted by "a wilde and saluage man" (4.7.5.1) who rapes and eats women. ${ }^{64}$ Like the inhabitants of early Britain the figure of Lust bears resemblance to accounts of savage peoples by travellers but he is also informed by the tradition of the Wild Man, particularly the medieval conception of the Wild Man as "an object of disgust and loathing, of fear and religious anxiety, the quintessence of possible human degradation" (White 1972, 22) ${ }^{65}$ Like the wooddwelling Irish, the Wild Man lives dangerously close to the civilized community "He is just out of sight, over the horizon, in the nearby forest, desert, mountains, or hills" (White 1972, 20).

The depiction of Lust clearly reveals anxiety about male genitalia:

His neather lip was not like man nor beast, But like a wide deepe poke, downe hanging low, 
In which he wont the relickes of his feast,

And cruell spoyle, which he had spard, to stow:

And ouer it his huge great nose did grow,

Full dreadfully empurpled all with bloud;

And downe both sides two wide long eares did glow,

And raught downe to his waste, when vp he stood,

More great then th'eares of Elephants by Indus flood.

(4.7.6.1-9)

His fully erect and ever ready male member is presented as his weapon and so it is fitting that he is chased and killed by Belphoebe, the representative of chastity, whom he fears:

Whom when that theefe approching nigh espide,

With bow in hand, and arrowes ready bent,

He by his former combate would not bide,

But fled away with ghastly dreriment,

Well knowing her to be his deaths sole instrument.

(4.7.29.5-9)

Belphoebe also represents Elizabeth, albeit in her personal aspect, and her actions against Lust show Elizabeth taking the kind of action against the uncivilized enemy requested by Irenius in the View. As we saw in chapter 2, stories of the savage Irish nature with its supposed history of cannibalism or near cannibalism and love of blood, are evident in the writings of English commentators on Ireland. Like the Irish, Lust is considered barbaric and his licentiousness is linked with the unnatural act of cannibalism.

The narrator cannot tell us anything about the origin of Lust, just as the origin of Britain's early savages is not known (2.10.8.1-2). Like the children in the View, said by Irenius to have absorbed the nature of their Irish nurses (Spenser 1949, 119), he has absorbed the nature of his feeders: "But whence he was, or of what wombe ybore, / Of beasts, or of the earth, I haue not red: / But certes was with milke of Wolues and Tygres fed" (4.7.7.7-9). Although Lust's origins are unknown his victims, Aemylia and Amoret, are both of high birth. Like her twin sister Belphoebe, Amoret was conceived by Titan's penetration of the virgin Chrysogone: "The daughter of Amphisa, who by race / A Faerie was, yborne of high degree" (3.6.4.2-3). She was nourished in the womb of her mother, referred to as "the sacred throne / Of her chaste bodie" (3.6.5.7-8), a nourishment which consisted not of "commune food" but rather of "vitall blood" (3.6.5.8-9). Like her sister Belphoebe, the enemy of Lust who brings about his death, Amoret has been "wondrously . . . begot, and bred / Through influence of th'heauens fruitfull ray" (3.6.6.1-2). The other woman who has been abducted by Lust, Aemylia, is also of noble blood. Her history is told twice in the narrative, once by herself to Amoret (4.7.15-18) and once by the squire Placidas to Arthur (4.8.50-51). In both versions the social background of the protagonists is stressed. Aemylia's relationship with the socially inferior Placidas, a coupling denounced by her father and her friends, prefigures her subsequent and grotesque coupling with Lust. The anxiety evident here about social miscegenation is present throughout the poem and is a central concern of the View. 
The abduction of Amoret by Lust is mirrored in an historical 'abduction'. In August 1591 Hugh O'Neill, the Earl of Tyrone, eloped with Mabel Bagenal, daughter of the retired Queen's Marshal Nicholas Bagenal and sister of the then Queen's Marshal, Henry Bagenal. This action enraged Mabel's family and undoubtedly tapped into New English fears about Native Irish lasciviousess. It is entirely possible that Spenser had O'Neill in mind when creating the savage man of Book 4. Despite his education amongst the English, O'Neill remained a hybrid figure who, as far as his New English neighbours were concerned, conformed to New English notions of Irishness. ${ }^{66}$ The belief that the Irish were lascivious fits O'Neill's sexual appetite; Mabel was O'Neill's third wife (see Morgan 1993, 79) and so it may be significant that, with the abduction of Amoret, Lust has three women in his cave. ${ }^{67}$ As far as the English were concerned the elopement of Mabel and O'Neill constituted a rape, being an attack on the property of one man, the father or husband of the woman, by another.

Although Timias has managed to kill the forester and his brothers who attacked him he has been badly injured in the process and requires assistance. The narrator announces that providence, either God's grace or fortune, has brought him "comfort" in the shape of Belphoebe. We know that Spenser intended Belphoebe to symbolize Elizabeth but it is not clear what the encounter between Belphoebe and Timias might represent. In "The Allegory of Chastity in The Faerie Queene" Frederick M.

Padelford argued that the historical allegory makes reference to Raleigh's romantic interest in Elizabeth, an interest that is futile because of their different social positions and therefore no offence to Elizabeth who constantly emphasized her virginal state (Padelford 1924, 375). John Upton, in his edition of the poem, was the first critic to notice that the later development of the story of Timias and Belphoebe, when she finds him with Amoret (4.7.35-37), dramatizes Elizabeth's anger at Raleigh's relationship with Elizabeth Throckmorton:

of all the historical characters here delineated, the most striking seems that of Sir W.R. whom we may trace almost in every adventure of the gentle squire Timias . . . Unfortunate man to fall under the displeasure of Belphoebe, the Virgin Queen! How could he presume to carry on a criminal amour with any one of her maids of honour? (Upton 1987b, 33)

Whilst these readings of the allegory are plausible it seems likely that the thrust is more general and the core of its symbolism lies in the initial meeting between Timias and Belphoebe rather than the romantic interest that later flourishes. No doubt Belphoebe represents Elizabeth but it is more probable that Timias, as a victim of Irish violence, is a representative of the New English colonialist in dire need of assistance from his queen. As with her defeat of Lust in Book 4, the depiction of Belphoebe as a martial virgin who provides succour is perhaps a fantasy that Elizabeth will come to the aid of her injured subjects in Ireland. There is a call for such aid in A Brief Note of Ireland. The tract, which is addressed "To the Queene", refers to the recent rebellion led by Tyrone which has resulted in "the ashes of disolacon [sic] and wastnes of this your wretched Realme of Ireland". Elizabeth should listen to the pleas of English men:

Pardon therefore moste gracious Soveraigne vnto miserable wreches, which without your knowledge and moste against your will are plunged in this Sea of sorrowes to 
make there euell case knowne vnto you and to call for tymelie redresse vnto you if yet at least any tyme be left which that your maiestie in your excellent wisdome may the better knowe how to redresse May the same vuchsafe to consider from what beginning the same first sprunge and by what late euill means it is brought to this miserable condicion which wee nowe Complaine of. (Spenser 1949, 236, lines 3744)

The cause of the rebellion is outlined and reasons given as to why the Irish hate the English before another plea is made for Elizabeth's aid: "[we] haue nowe nothing left but to cry vnto you for tymelie aide before wee be brought to vtter distruction" (Spenser 1949, 241, lines 220-21). As in the View, the speaker urges Elizabeth to deny mercy to the rebellious Irish. The use of force and famine is necessary in dealing with them and essential if Elizabeth is to show the compassion she owes to her English subjects.

In Book 4 of The Faerie Queene Spenser makes explicit the fusion of the landscape with the political, historical, and social concerns of the poem when he devotes an entire canto to the description of the marriage of the Thames and the Medway (4.11). The canto is a celebration of colonial power which is linked to the concept of nationhood and the governance of waters.

The marriage, which takes place in the natural world, mirrors the betrothal of Britomart and Artegall (4.6.40-41) and, as in Book 3, emphasizes the importance of chaste love. The history of the rivers and their relationship to each other is a continuation of the central concern of the chronicles in Book 2 which highlights the importance of English history, the place of the house of Tudor within it, and the function of Britomart and Elizabeth as part of the Tudor family. The river's lineage mirrors that of Britomart's progeny which is said to come from the Trojan Kings who claimed to be related to the classical gods, who were not only immortal but also royal.

Neptune appears with his queen Amphitrite whose physical beauty is described:

And by his side his Queene with coronall, Faire Amphitrite, most diuinely faire, Whose yuorie shoulders weren couered all, As with a robe, with her owne siluer haire, And deckt with pearles, which th'Indian seas for her prepaire. (4.11.11.5-9)

The description of Amphitrite is consistent with contemporary

Petrarchan descriptions of Elizabeth, with an emphasis on precious materials: ivory, silver and pearls, the last being particularly associated with the queen (Yates 1947, 74-75). The same Petrarchan motifs are utilized in the depiction of the bride (Medway), her handmaids, and the nymphs, whose beauty is described in terms of precious metals, long hair, flowers, and pale skin (4.11.45-51). The physical description of Amphitrite also alludes to English colonial expansion with the notion that the Indian seas serve the queen, prepare pearls especially for her, and so are willing aquatic subjects. The colonial allusion is particularly clear in the narrator's description of the royal issue: first the seventeen sea gods who govern the waves, 
then the nine founders of Nations who control the world (4.11.13-16). This emphasis on nationhood and the governance of waters mirrors contemporary conflicts over the ownership and governance of land. Colonial expansion is highlighted when the narrator lists famous rivers of the world including "Rich Oranochy, though but knowen late; / And that huge Riuer, which doth beare his name / Of warlike Amazons, which doe possesse the same" (4.11.21.7-9). Raleigh refers to the Orinocho throughout his Discovery of Guiana which was first published in 1596, the same year as Books 4-6 of The Faerie Queene. The narrator then refers to the "warlike Amazons" who live in the region between the Orinoco and the Amazon and proceeds to make a plea for the colonization of Guiana:

loy on those warlike women, which so long Can from all men so rich a kingdome hold; And shame on you, O men, which boast your strong And valiant hearts, in thoughts lesse hard and bold, Yet quaile in conquest of that land of gold. But this to you, O Britons, most pertaines, To whom the right hereof it selfe hath sold; The which for sparing litle cost or paines, Loose so immortall glory, and so endless gaines.

$(4.11 .22 .1-9)$

This is the only reference to amazons in The Faerie Queene prior to Artegall's confrontation with Radigund in Book 5. Men who allow themselves to be ruled by women, even strong "warlike" women, are weak claims the narrator. This prefigures the gender inversion in Book 5: the feminization of Artegall at the hands of Radigund which epitomizes masculine weakness and shame. When Britomart takes control of the city of Radegone from Radigund she shares power with Artegall, unlike Elizabeth she does not rule alone.

The exhortation to colonize Guiana (4.11.22) emphasizes the benefits of exploiting the landscape. Simon Shepherd detects in the exhortation Spenser's backing for the policies of the militant Protestant faction of Raleigh and Essex in the 1590s and his support for Raleigh's call to colonize the Americas:

The Amazons of South America are an invitation to British men to act out the policies of international Protestantism. They are an incitement to Raleigh to prove himself a hero of the faction, a modern day Theseus, by conquering the Amazons, by colonising South America. (Shepherd 1981, 28)

The passage also alludes to Ireland and Elizabeth's reluctance to spend money in the Irish wars. In the View Irenius claims that money has been misspent and mismanaged: Elizabeth has provided the money in small amounts rather than a lump sum and this has caused problems, Irenius asserts. With just 10,000 footmen and 1,000 horsemen the problem could be under control in a year and a half (Spenser 1949, 149-51).

Ireland is explicitly referred to in the description of the Irish rivers (40-44) which run through "saluage cuntreis" (4.11.40.9). The reference to the "balefull Oure, late staind with English blood" is thought by P. W. Joyce and A. C. Hamilton to allude to 
the defeat of Lord Grey on the banks of the Avonbeg at Glenmalure in 1580 (Spenser 1935, 271; Spenser 1977, 516). The poetic implications of the river stained with blood are numerous: it suggests that the savagery of the Irish pollutes the very landscape, (as with the forester in Book 3) and its waters, that the defeat of the English will not be forgotten because their blood has made an indelible mark on the Irish water, and that there has been an undesirable mixture of Irish fluids and English blood. English blood spilled on the Irish landscape and absorbed by Irish rivers seems to be a metaphor for the miscegenation repeatedly lamented by Irenius in the View and evident in the union of Hugh O'Neill and Mabel Bagenal.

The landscape of Fairyland shares many characteristics with early modern Ireland. It is attractive but also unpredictable and dangerous. On the surface it is innocuous but it hides terrors within its woods. Anxiety about danger that is hidden is also evident in the malevolent women who occupy Fairyland. Like the Irish landscape such women are deceptive. Their beauty conceals a degenerate interior which, like the Irish interior, is harmful to their enemies. The marriage of the Thames and the Medway (4.11) is a fusion of sexual and cartographic control. Just as marriage is an official containment of sexuality so the process of making maps contains land and allots ownership. The inability to make maps because of native hositility is like the inability to enforce chastity and marriage because of sexual promiscuity. Evident in both is a failure to assert control. In The Faerie Queene women who ideologically or actively defend chastity, and therefore marriage, are set against those women who are sexually promiscuous. The desire to contain female sexuality via marriage is analogous to the desire for physical and ideological control of the Irish landscape. The sexually promiscuous Duessa, who conceals her depravity, is a metaphor for degenerate Ireland which if left unknown will also, like Duessa, be ungoverned and ungovernable. Just as sexual laxity should be replaced by chastity so the Irish landscape must be surveyed, accounted, laid bare, and so civilized. Gaelic Brehon law, viewed by the English as lax, should be repaced by the English law of primogeniture. Just as sexual degeneracy makes the body weak and its interior (its spirit or soul) diseased, so political rebellion, the poem tells us, makes those who inhabit the land and sometimes the land itself sick. The political solution for the colonizer is to cut through the landscape and rid it of rebellion thus asserting control upon a hostile and unpredictable environment.

\section{Chapter 6}


The Plight of Munera: Violence against the Sexual and Religious Other

The use of political violence to correct what is presented as Catholic lawlessness is evident both in The Faerie Queene and the View. The major political themes of Book 5 are the rebellion in Ireland, the trial of Mary Queen of Scots, and the conflict in the Netherlands against Spain. All were regarded by the English Protestant state as the result of Catholic lawlessness. The main quest of Artegall, the knight of justice and hero of Book 5, is to free "the faire Irena" held prisoner by Grantorto, the giant who represents Catholic power. The allusions to Ireland in Book 5 are overt. ${ }^{68}$ As A. C. Hamilton points out in his edition of the poem, Irena is an anagram of lerna which, according to William Camden, was the classical name for Ireland. ${ }^{69}$ It is also significant that 'Irenius', the name of the speaker who advocates violence against the Irish in the View, appears to be a masculine form of Irena.

This chapter will explore a brief and neglected episode which occurs in Book 5 canto 2, where economic corruption is gendered and sexualized in the figure of Munera. ${ }^{70}$ Munera is the daughter of the villain Pollente who, with his groom Guizor, robs and kills anyone who wishes to pass over his bridge. Pollente takes their riches whilst Guizor steals their hair and skin. Munera accepts the stolen riches from her father and her corruption is symbolized by her golden hands and silver feet which "sought vnrighteousnesse, and iustice sold" (5.2.26.8). She attempts to bribe Talus, the iron man who serves Artegall, with gold. Before killing her, Talus cuts off her hands and feet, destroys the stolen gold she has accepted from her father and sets fire to their castle.

This chapter will argue that Munera is the focus of Spenser's intense feelings about Catholic economic corruption and Petrarchan anatomizing of female beauty. Munera's death is arguably the most violent and troubling moment of the entire poem and Talus's behaviour is utterly lacking in the pity demonstrated by other agents of virtue.

Munera (Latin 'rewards', 'presents') has been identified by critics as a non-specific symbol of bribery and corruption ${ }^{71}$ but few have spotted that the episode illustrates specifically Catholic economic corruption. An Irish Catholic connection has been noted by some critics ${ }^{72}$ but I intend to show that Spenser's allusion is focused specifically on the Catholic cult of anthropomorphic reliquaries and the tradition of the poetic blazon.

Munera is identified with Langland's Lady Meed by Alfred B. Gough in the commentary to his editon of Book 5:

With the crafty ruffian Pollente is associated his daughter. Lady Munera, the traditional Lady Meed whom Langland had introduced into English literature, represents the allied but subtler and one might say more feminine injustice which 
Fitzpatrick, Joan. 2000b. Irish Demons: English Writings on Ireland, the Irish and Gender By Spenser and His Contemporaries. Lanham. University Press of America.

consist in taking and giving bribes and favours to pervert the right. (Spenser 1918, 176). ${ }^{73}$

Spenser's source for the depiction of Munera may be traced back even further than Langland, to a medieval apocryphal legend of the Daughters of the Devil. Drawing upon the research of Barthélemy Hauréau, G.R. Owst recounts the legend in his Literature and Pulpit in Medieval England. Before he was expelled from heaven, Satan married Iniquity, the original Queen of Hell, who became the mother of Antichrist. In the legend she gave birth to daughters, which different accounts number from six to nine and who personified vices which included the seven deadly sins. Owst claims that this legend:

provides us with the source from which William Langland must have drawn the idea of his Lady Mede, daughter of Falsehood or the Evil One. . . . Later again in the same century the story makes prominent reappearance in verse in Gower's Mirour de l'Omme, or Speculum Meditantis; while the Lady Munera of Spenser's Faerie Queene is a noteworthy instance of its survival in Tudor times. (Owst 1961, 96-97)

The Pope was often identified as the Antichrist in Protestant commentaries, such as that accompanying the 1560 edition of the Geneva Bible which says of the Whore of Babylon: "This woman is the Antichrist, that is, the Pope with ye whole bodie of his filthie creatures . . . Whose beautie onely standeth in outwarde pompe \& impudencie and craft like a strumpet" (Anon. 1560, GGg4 note f). If Munera can be associated with the Antichrist then the Munera episode can most satisfactorily be read as a Protestant critique of economic exploitation by the Roman Catholic Church. Further evidence of Munera's Catholic, and hence diabolical, associations is her parentage: Pollente is "a cursed cruell Sarazin" (5.2.4.6) and, as Richard McCabe has pointed out, paganism is associated with the Roman Catholic Church throughout The Faerie Queene (McCabe 1989a, 112). E. H. Blakeney suggests that the narrow bridge on which Pollente exacts his tolls is reminiscent of the Al-Sirat bridge in Muslim mythology which was narrower than the edge of a sword and built across the abyss of hell (Spenser 1936, 213). As we saw in chapter 1, ignorant Roman Catholics are explicitly identified with unbelievers by Irenius in the View:

Therefore the faulte that I finde in religion is but one but the same vniuersall throughe all that Countrye, that is that they are all Papistes by theire profession but in the same so blindelye and brutishly enformed for the moste parte as that ye woulde rather thinke them Atheists or infidels but not one amongest a hundred knowethe anye grounde of religion anie article of his faithe but Can perhaps saie his pater noster or his Ave marye without anie knowledge or vnderstandinge what one worde theareof meanethe/ (Spenser 1949, 136)

Given her diabolical parentage, the association of the Pope with the Antichrist, and Spenser's apparent disdain of Catholic wealth, Munera's golden hands and silver feet suggest the Catholic Church's supposedly ill-gotten wealth and unscrupulous economic practices. Munera is a symbol of the Catholic corruption which was believed to have flourished on the continent and to have come nearer home in the Spanish wealth that fuelled Irish insurrection. 
As an allegory of bribery and corruption in a Catholic context Munera is part of a larger recurrent feature of The Faerie Queene which is the demonization of Elizabeth's Catholic enemies. Munera's golden hands and silver feet symbolize her traffic with the rewards of corruption but her precious body parts also evoke Petrarchan descriptions of female beauty. Petrarch's Rime Sparse ('scattered rhymes'), or the Canzoniere as it was also known, had an enormous impact on the Renaissance concept of beauty. Nancy Vickers has explored the metaphorical dismemberment of Laura by Petrarch's speaker (Vickers 1981, 266) and the violent nature of the blazon by which the woman described is converted into an object (Vickers 1985, 97). As Vickers points out, Petrarch's Rime Sparse "did not constitute the first example of particularizing description, but it did popularize that strategy by coming into fashion during the privileged early years of printing" (Vickers 1981, 277). Petrarch's speaker describes Laura using images of precious materials. As Vickers puts it: "Her textures are those of metals and stones; her image is that of a collection of exquisitely beautiful disassociated objects" (Vickers 1981, 266). Munera is partly constructed from beautiful, metal objects and yet Talus also may be said to be partly-Petrarchanized in that he is formed not from flesh but from iron. ${ }^{74}$

As A. Leigh DeNeef has pointed out, the cannibals who molest Serena in Book 6 take to a literal extreme the violent desires latent in the blazon because they want to literally dissect and consume her (DeNeef 1990, 637). These aggressive impulses are contained however when the virtuous lady is rescued from her aggressors by Calepine (6.8.45-49). Unlike Serena, Munera is morally degenerate and it is this which allows the violent impulses toward her to become actualized. That she is a literal embodiment of the blazon is evident in her precious body parts and the eventual dismemberment of them by Talus. There is no reason to contain male aggression toward this woman because she 'deserves' the violence inflicted upon her. In the attack on Munera, Spenser's antagonism toward Catholic Irish corruption is allowed free rein.

Whilst it is not surprising that modern feminists should feel uncomfortable with the poetic blazon's potentially misogynistic dissection of the female form, Vickers might usefully have considered the possiblity that a poet employing the poetic blazon might have ambivalent feelings about it. As evidenced in his portrayal of Talus, Spenser's use of the blazon is not straightforward. Spenser may be using parody, either of the blazon itself or of poetic desires expressed in this form. An example of Spenser's use of parody can be found in Book 3 of The Faerie Queene in the creation of the False Florimell. The crudity of the figure is unmistakable, as is the selfconsciousness of the description:

The substance, whereof she the bodie made, Was purest snow in massie mould congeald, Which she had gathered in a shadie glade Of the Riphoean hils, to her reueald By errant Sprights, but from all men conceald: The same she tempred with fine Mercury, And virgin wex, that neuer yet was seald, And mingled them with perfect vermily, That like a liuely sanguine it seem'd to the eye. (3.8.6.1-9) 
In stead of eyes two burning lampes she set

In siluer sockets, shyning like the skyes,

And a quicke mouing Spirit did arret

To stirre and roll them, like a womans eyes;

In stead of yellow lockes she did deuise,

With golden wyre to weaue her curled head;

(3.8.7.1-6)

Although the False Florimell appears to be an ironic comment upon the excesses of the Petrarchan tradition, parody must surely be ruled out in Spenser's

Epithalamion (written to celebrate his second marriage) which is located within the same tradition:

Her goodly eyes lyke Saphyres shining bright,

Her forehead yuory white,

Her cheekes lyke apples which the sun hath rudded,

Her lips lyke cherryes charming men to byte,

Her brest like to a bowle of creame vncrudded,

Her paps lyke lyllies budded,

Her snowie necke lyke to a marble towre,

And all her body like a pallace fayre ... .

(Spenser 1947, 245, lines 171-178)

Spenser could conform to tradition and also parody it so perhaps we should be cautious about ascribing to him the misogynistic motives which Vickers detects behind the blazon form.

In the depiction of Munera it seems that Spenser was at least partly influenced by the poetic blazon but, as with the description of the False Florimell, he subverts the tradition. Similitude gives way to identity in the Munera episode which violates the rules of the blazon which dictate that a woman's hands and feet should be like, but not actually consist of, a precious material. It is her precious body parts and what they represent that makes Munera's death tolerable. Her metal extremities make her monstrous and she is perhaps a comment upon the excess of Petrarchan hyperbole as well as a comment upon Catholic financial excess.

All the female victims in Book 5 are connected in some way to the violence which is supposedly due to Catholic corruption. Belge (the Low Countries) and Flourdelis (France) suffer at the hands of the enemies of Protestantism-though Flourdelis is to some degree complicit with her aggressors-whilst Munera, Duessa, the Amazon Radigund and her women, who are the enemies of Protestant goodness and truth, are dealt with according to the rules of justice. It is the function of Artegall, with the help of Talus, and of Arthur and Britomart to destroy the enemies of peace, and justice.

Judith Anderson detects a crucial problem with Book 5: although justice is the most exalted moral virtue in The Faerie Queene, Artegall "seems the most disappointing and ineffectual hero in the entire poem" $(1970,65)$. Anderson identifies part of this problem to be that justice is a social virtue and so, unlike the other virtues 
represented in the poem, it is external to an individual. This, she claims, is not generally the case in earlier books where the world is "inly' ours", by which I take Anderson to mean that these earlier books explore personal virtues $(1970,67)$. Anderson identifies "both the historical and the symbolic poles in Book V" and claims that Artegall is divided against himself from the beginning of the book (Anderson $1970,66)$. He exists simultaneously as the virtue 'justice', which is an abstraction, and the virtuous knight who is a human being. Anderson applies this polarity to Munera in an attempt to explain the uncomfortable reaction we have to her pain and mutilation at the hands of Talus:

To the degree that she is 'inly' ours we tend to pity her; yet our pity is frustrated by her metal hands and feet. On the one hand Lady Munera reminds us just a little too much of an attractive but misguided young woman, led astray by a wicked but indulgent parent (witness Poeana); on the other hand she is a mechanical allegorization of a special form of social corruption (even Poeana lacks metal hands and feet). There is a definite strain in the surface of the poem as we are alternately drawn toward, or pushed away from, Lady Munera. (Anderson 1970, 67)

Anderson's insightful comment alerts the reader to the tension in Spenser's allegory between humanity and abstraction. This strain between character and symbolic meaning, between Munera as woman and Munera as allegory, becomes apparent in the ferocity of Talus's attack. It seems that Spenser has simply done too good a job creating a realistic scene of pain and mutilation. Anderson rightly questions William Nelson's suggestion that the fact that Munera's body parts are metal exonerates Artegall (Anderson 1970, 67). Nelson attempts to minimize the violence perpetrated against Munera: "In his role as executioner he chops off her hands and feet (not as brutal as it sounds for they are made of gold and silver) and nails them on high for the edification of all" (Nelson 1963, 264). Anderson's discomfiture is well founded, since Munera's metal hands and feet "cannot cancel the dominant tone of the passage, even though they fail to harmonize with it" (Anderson 1970, 67-68). Like C. S. Lewis, many modern readers are disturbed by Spenser's apparent lack of compassion in Book 5 (Lewis 1936, 347-50). The same lack of compassion is evident in the opinions expressed by Irenius in the View. Here Irenius clearly states that there is no place for pity in war:

Therefore by all meanes it muste be forsene and assured that after once entringe into this Course of reformacion, theare be afterwardes no remorse or drawinge backe, for the sighte of anie suche rufull obiectes as muste thearevppon followe, nor for Compassion of theire Callamityes, seinge that by no other meanes it is possible to recure them, and that these are not of will but of verye vrgente necessitye/ (Spenser 1949, 163) ${ }^{75}$

The principles endorsed by Irenius are directly applied to Munera, the "rueful object" who urges Artegall to feel compassion for her calamity. Artegall feels compassion, but recovers himself and allows Talus to butcher Munera.

It might be argued that modern literary critics overplay the significance of physical suffering. For Spenser, humanity resides in the soul rather than the body. Munera must suffer physical death in order to enjoy spiritual redemption: her body must be dismembered so that her corrupt soul can become pure. But if the soul can 
be redeemed only by physical destruction we might ask why other corrupt women in the poem, many of them more corrupt than Munera, do not suffer a similar fate. We might also ask why the death of Munera is so savage, why mutilation is a necessary factor in the punishment, and why the punishment is gratuitously drawn out. It is in the nature of the poetic text to elicit emotional response and as readers we are disturbed by the intensity of Munera's suffering even though we know that she deserves punishment.

What Munera's destruction lacks is the effect of pity which operates elsewhere in Spenser's Fairyland. Pity is shown not only by Artegall towards Munera, but by Britomart towards the people of Radegone (5.7.36.4-9), and by Arthur and Mercilla towards Duessa (5.9.46-50). Britomart revokes the power of usurping women in Radegone so we should not be surprised if she displays some 'feminine' weakness by sparing lives. Yet the pity shown by Artegall, Mercilla and Arthur is finite for they overcome their weakness and allow justice to take its course. In The Faerie Queene pity threatens the execution of justice and the consequence of a momentary lapse is fully explored later in the narrative when Artegall is defeated by Radigund. Artegall makes the mistake of showing pity, which is a direct result of sexual attraction, and he is at once vanquished (5.5.13-17). In the Munera episode Spenser explores most fully what horrors must be withstood if pity is not to be allowed to undermine justice.

The fight between Artegall and Pollente is straightforward male-to-male, hand-tohand combat. Their strengths are equal and when Artegall decapitates Pollente he kills his physical equal. ${ }^{76}$ The same cannot be said about the encounter between Talus and Munera. Talus is endowed with superior strength and it might be argued that the excess evident in his punishment of the physically weaker Munera makes her punishment sadistic. As Gough notes, Munera's punishment "is more severe than that inflicted on any of the other evil women in the poem" $(1918,176)$. Why is Munera subjected to such brutality? The answer may be that this episode is an attempt by Spenser to convince the reader that Catholic corruption must be destroyed despite its splendour and that those who perpetrate wrongs must be punished despite any pity they may provoke. Spenser appears to be saying that despite her beauty, despite her femaleness, and despite her heart-rending pleas for pity, Munera is guilty and must be punished. The law enforcer must be ruthless to instil law and order. For some readers, however, it appears that Spenser's art fails to convince at this point and the punishment of Munera is excessive and sadistic. The violence directed toward Munera may betray Spenser's unease at the pitiless violence current in Ireland and his own complicity in it. Spenser might rationalize such violence on a practical level as being a just and effective deterrent, but it appears also to offend his poetic sensibilities.

It has gone unnoticed by critics that Pollente's groom Guizor, whose name evokes the house of Guise and thus the Catholic League, embodies the supposed Catholic corruption evident in the cult of relic worship. ${ }^{77}$ An allusion to the cult might be evident in Guizor's method of robbing the poor: the literal and aggressive fragmentation he enacts by cutting off their hair and skin. The allusion is extended by the mutilation of Munera. Her dual role as a personification of the Catholic economic corruption which funded rebellion in Ireland and as a beautiful woman with unnatural body parts strongly suggests the Catholic cult of relic worship: her valuable hands 
and feet are in essence reliquaries. Caroline Walker Bynum relates that in the medieval period holy bones were owned and worn as private objects of devotion (Bynum 1992, 271). Paul Williamson and Bynum agree that the bones were often stored in reliquaries shaped like the part of the body from which the bones had come. Williamson states that "The bones of venerated saints were often housed in reliquaries which took the appropriate shape: heads, hands, arms and feet were encased in silver and gold, frequently embellished with gems" $(1986,180)$. Both authors reproduce a photograph of a thirteenth-century Flemish hand reliquary which is currently in the Victoria and Albert museum in London. The hand is made of gold and the fingers have crystal windows through which the viewer can see the finger bones. Williamson further speculates that this particular hand reliquary originally formed part of an arm reliquary, from which it was detached at an uncertain date (Williamson 1986, 180). Such anthropomorphic reliquaries appear to have influenced Spenser's depiction of Munera and provided a powerful image with which to materialize the Petrarchan conceit of describing a woman's body parts in terms of precious materials. The two traditions come together in a violent fantasy centred on the figure of Munera in which metaphorical dismemberment becomes literal. The intensity of his anti-Catholic feelings made Spenser run the idealization and the relicmaking processes in reverse. The Catholic process of death, followed by dismemberment, and the substitution of precious metal for decayed flesh becomes in the Munera episode the unnatural possession of precious body parts which are rightly cut off, leading to death. Petrarch idealizes the living body parts, Catholics idealize the dead, and the two idealizations merge in Munera. The result in the Munera episode is a mirror of the usual Catholic process and Munera is consciously created by Spenser as an inverted saint.

A religious iconography is emphasized by the posture Munera adopts when pleading for mercy: "Still holding vp her suppliant hands on hye, / And kneeling at his feete submissiuely" (5.2.26.4-5). Spenser ironically figures Munera as a Christian martyr struck down in the posture of prayer and so parodies any claims Catholics might make to genuine martyrdom. Yet the posture also emphasizes her humanity and thus the cruelty of Talus. The religious aspect of the characterization of Munera is also evident in an apparent parody of Christ's crucifixion when her literally fragmented body parts are "Chopt off, and nayld on high, that all might them behold" (5.2.26.9). Although the display of dismembered body parts was common after executions in sixteenth-century England, it was usual for the victim to have been hung, drawn, and quartered. The nailing of hands and feet, as opposed to the more common contemporary practice of quartering, alludes specifically to the crucifixion. Presumably Spenser thought such a parody fitting for a representative of the Catholic church which claimed to glorify the true Christ but was accused by some Protestants of worshipping the Antichrist.

Munera is a gendered and sexualized embodiment of a revulsion of Catholicism. Her violent death occurs in Book 5 of the poem, the one which contains the most overt allusions to Ireland, so it might be claimed that her fate is a comment upon the violent situation in early modern Ireland. Yet Book 5 also alludes to the conflict in the Netherlands against Spain and so Spenser might have been influenced by the story of the evil giant Druon Antigoon which is linked to the etymology of the name of the town of Antwerp. According to Jan L. R. Van Roey, the city's honorary archivist, Antigoon demanded extortionate tolls from the boatmen on the river and severed 
their hands if they refused to pay. The Roman soldier Silvius Brabo fought Antigoon, cut off one of the giant's hands, and threw it into the river. This action, 'to throw a hand' (ant-werpen), supposedly gave the city its name. Van Roey further states that "Antwerp's coat of arms consists of a fortified castle with a hand on each side; and in the Great Market, in front of the 16th-century Town Hall, the Brabo Fountain (1887) depicts the legendary event" (Van Roey \& Sankovitch 1993, 807). ${ }^{78}$

Although the Dutch legend might have provided the idea of mutilating a toll-taker, thematic consistency in the Munera episode makes this primarily an Irish allusion. Munera is constructed in opposition to Irena, the temperate, spiritually beautiful, and oppressed woman whose rescue constitutes Artegall's quest in Book 5. Like Una in Book 1, Irena simultaneously represents the land of Ireland, held in subjection to tyrannical Catholic power, and the rightful ruler of that land. Through the use of nautical imagery in the View the land is also compared to a ship, which suggests not only the necessary voyage by sea to gain mastery of Catholic Ireland but also a familiar feminization of that which must be controlled. Irenius states that, through rebellion, the ship's "Principall partes haue bene rente and torne a sunder". Catholic aggression, figured in Grantorto and Pollente amongst others, oppresses Irena in Book 5 and is responsible for what is referred to by Eudoxus in the View as Ireland's "mishapps ... whearein she hathe thus wretchedlye bene wrecked". According to Irenius, Elizabeth's Lord Deputy, Grey, had "like a moste wise pilott" steered the ship, "helde her moste stongelye even againste those roringe billowes" of rebellion, and "safely broughte her out of all" (Spenser 1949, 63). ${ }^{79}$ Munera also constitutes the feminization of that which must be controlled by violent retributive justice. Ireland has metaphorically been "rente and torne a sunder" by rebellion and to end insurrection Munera must literally suffer the same fate at the hands of Talus.

It might be objected that Munera should not be loaded with such immense ideological significance considering the brevity of the episode in which she appears, and yet she stands as the most tormented woman in an epic poem littered with bodies, whole and dissevered. She functions on at least two levels: as a beautiful woman who, with her precious and severed body parts, literally fulfils the demands of the Petrarchan conceit, and as a personification of the supposed economic corruption of the Catholic church. In the latter sense she is a symbol of the production of anthropomorphic reliquaries in reverse. This allows Spenser to present her as an inverted saint, a monstrous figure who betrays the cupidity of Catholic relic worship. The violence perpetrated against her is both political and sexual for it at once represents the violence of post-Reformation politics and the aggressive tendencies of the Petrarchan conceit.

If we accept that there is a connection between the poetic blazon and Munera's precious body parts then we have to consider why this particular example of Petrarchan fragmentation is so extreme. Why does the poet leap from traditionally acceptable metaphorical fragmentation, a central feature of the Petrarchan tradition, to literal fragmentation involving brutal violence? The Faerie Queene is a violent poem and Book 5, which features Munera, is perhaps the most violent of the six complete books. Book 5 is extreme in a variety of ways. The metal man Talus is what we might call a part-Petrarchanized ideal of the man of justice, and so is an extreme example of flesh made metal. Munera is also an example of flesh made metal, but unlike Talus she is a victim, the recipient of the most extreme act of 
violence against any woman in the poem. The connection between Book 5 and Ireland resides not only in the transparent allusions to colonial activity in Ireland but also in Talus whose actions typify the extreme violence recommended by Irenius in the View. The image of Talus as automated husbandman, the machine threshing the Protestant corn and disposing of the Catholic chaff, permeates Book 5. By fusing in the single figure of Munera his revulsion of relic worship and his at least partlyrealized Petrarchan aggression, Spenser created a female character by whose destruction he could temporarily release extraordinarily violent feelings. It might be that such a spasm of violence acts as a safety-valve, liberating the tension that has accumulated in the poem and at the same time attempting the containment of subsequent aggression.

\section{Chapter 7}

\section{Pastoral Idylls and Lawless Rebels}

In The Faerie Queene rebellion is expounded in sexual terms, and a nationalistic agenda appears evident in the fusion of the sexual and the territorial. The political issues of governance and control of a territory are presented via sexual dynamics whereby a woman's body is used as a symbol for the process of colonization and sexual dominance. The episodes featuring Pastorella (6.9-12) and Serena (6.8.3551) are typical of the tension that exists within Spenser's idealization and demonization of the pastoral existence. As more disturbing examples of discourtesy, images of aggression and sexual degradation are central to Spenser's depictions of debased, as opposed to idealized and courteous, pastoral life. Since critics concur that there are Irish dimensions to the uncivilized mobs who threaten Pastorella and Serena, then we might ask what role these female victims of mob violence play in the allegory. In both episodes Spenser uses beauty as an important signifier in his conception of English nationalism and his representation of political and sexual difference. In chapter 5 we saw that specific episodes betray an anxiety about New 
English Protestants as victims of Irish Catholic savagery. This chapter will consider how far this colonial anxiety is evident in the episodes featuring Pastorella and Serena.

In the case of Pastorella, beauty is used as a metaphor for inherent nobility which implies civility, goodness and, most importantly, English Protestant superiority. This suggests that Pastorella is an ideal, a symbol of the New English colonist in Ireland who, it is hoped, will remain untouched by the influence of the people amongst whom she or he lives. Serena falls asleep in a wood and is sexually assaulted and nearly eaten by the Saluage Nation, which similarly suggests New English fear of Native Irish violence expressed through metaphors of sexual penetration and consumption.

Innocent Pastorella is abducted by the Brigants but Serena is attacked by the Saluage Nation because she has ventured into their territory, a circumstance which makes the episode somewhat problematic because it may indicate a degree of complicity on her part. The only other episode in the poem in which a woman is molested by a group of savages (as opposed to an individual savage man) occurs in the Flourdelis episode in Book 5. The allegory here is transparent: she represents France as a lady who was once loyal to her Protestant champion but has been unfaithful. Her collusion with the enemy is more overt than Serena's and, although virtually ignored by critics (she has no entry in the usually thorough Spenser Encyclopedia), the episode deserves analysis in the context of those featuring Pastorella and Serena.

The tension evident in Spenser's conflicting representations of agrarian existence reveals anxieties about Catholic (particularly Irish) resistance and betrays concerns about political control in the colonial project. These anxieties are betrayed via the concept of violent sexual relations and the threat of miscegenation. Catholic rebellion, blame, punishment and sexual degradation-or the threat of these-is central to the Pastorella, Serena, and Flourdelis episodes. A useful parallel text that may illuminate these aspects of The Faerie Queene is the View.

Pastorella's name identifies her with the pastoral environment she inhabits. Her foster father, Meliboe, praises the pastoral existence, emphasizing its freedoms, selfsufficiency and the contentment it brings. It is a peaceful existence and its inhabitants are without pride or ambition (6.9.20-25). Calidore admires its freedom: "How much (sayd he) more happie is the state, / In which ye father here doe dwell at ease, / Leading a life so free and fortunate" (6.9.19.1-3). There is, however, evidence of an ambivalence towards rural life throughout The Faerie Queene. As was discussed in chapter 5, Irenius describes the Irish landscape as both sinister and beautiful. He comments on the physical beauty of Ireland and its economic usefulness (Spenser 1949,62) but also expresses a fear of the Irish landscape and urges the clearing of woodland in order to make it safe for travellers (Spenser 1949, 224). In the Pastorella episode the life of the shepherd is idyllic. Calidore comes across the shepherds

Playing on pypes, and caroling apace, The whyles their beasts there in the budded broomes Beside them fed, and nipt the tender bloomes: 
For other worldly wealth they cared nought.

(6.9.5.3-6)

Yet quite a different opinion is given of animal farming in the View where Irenius denounces as Scythian the practice of 'booleying' or transhumance which was an essential part of Irish pastoral reality (Spenser 1949, 97-99). As Nicholas Canny observes in The Elizabethan Conquest of Ireland, the association of the nomadic Scythians with the Irish meant that "Here was evidence to satisfy Spenser that the Irish were indeed true barbarians, and this notion also became entrenched in the minds of sixteenth-century Englishmen" (Canny 1976, 127). Irenius objects that the booleys harbour "outlawes or loose people" who "growe theareby the more Barbarous and live more licentiouslye then they Could in townes", conspiring against the government and individuals. They steal, they murder, and think themselves to be exempt from the law. He concludes that such "fredome" is dangerous for "havinge once tasted fredome ... . [they] grudge and repine ever after to Come vnder rule againe" (Spenser 1949, 98). Why is it that the freedom celebrated by Calidore in the Pastorella episode is condemned as subversive in the View?

In his study of the Elizabethan pastoral form, Louis Montrose has noted that in the early modern period figurative pastoralism borrowed from literal pastoralism but rejected the harsh reality of its labour. The task of sheep herding was valorized and agrarian labour excluded from the vast majority of Elizabethan pastoral texts. This had its basis in the Biblical moral hierarchy of Cain, a tiller of the ground, and Abel, a shepherd. Furthermore, the process was class-based: literary pastoralism was dominated by aristocratic values and style even though most of its poets had humble origins. English literary pastoralism placed great emphasis on leisure in an attempt to mimic the leisure of the gentry who found manual labour unappealing. In pastoral literature the shepherd's toil is minimal and the manual labour required for other agrarian tasks is ignored. The main thrust of literary pastoralism was the imaginative creation of an elite society by a burgeoning middle class in an attempt to bring aristocratic values to the practice of sheep herding (Montrose 1983). In the Pastorella episode, the pastoral idyll is invaded by the "lawlesse" Brigants who live on the periphery of the pastoral world. The Brigants are worse than the lowly ploughman because they live from theft. There is a tension between the figurative pastoralism of Spenser's imagination and the literal pastoralism of his real world, that is, his experiences in Ireland where Irish rebels proved to be a continual threat to the New English settlers. The attitude toward the landscape of Ireland in the View is ambivalent: the landscape is sometimes admired for its beauty and at other times feared for its dangers. Such ambivalence is not evident in the descriptions of the people who inhabit the landscape: attacks upon the Irish rural culture evident in their farming methods, particularly transhumance, are consistent.

Although Pastorella is part of the pastoral community, she is at the same time separate from it, due to her origins. She has been fostered by Meliboe and his wife, but she has not been fully assimilated, and her inherent superiority is apparent. When Calidore first sees her she is seated "Vpon a litle hillocke . . . / Higher then all the rest" (6.9.8.1-2). As Sheila Cavanagh points out, "Pastorella is raised both literally and figuratively above her pastoral companions" (Cavanagh 1994, 125). Her inherent nobility sets her apart from those around her and manifests itself in her extraordinary beauty: 
And soothly sure she was full fayre of face,

And perfectly well shapt in euery lim,

Which she did more augment with modest grace,

And comely carriage of her count'nance trim,

That all the rest like lesser lamps did dim:

Who her admiring as some heauenly wight,

Did for their soueraine goddesse her esteeme,

And caroling her name both day and night,

The fayrest Pastorella her by name did hight.

(6.9.9.1-9)

Despite growing up amongst humble people, Pastorella's innate nobility remains intact. She rejects as her suitor the lowly shepherd Coridon and others like him: "Yet neither she for him, nor other none / Did care a whit, ne any liking lend: / Though meane her lot, yet higher did her mind ascend" (6.9.10.7-9). This concept of inherent nature is central to the View. Irenius is strongly critical of the Old English who have forgotten their English nature and become degenerate:

the Englishe that weare are now muche more Lawles and Licentious then the verie wilde Irishe, so that as muche Care as was then by them had to reforme the Irishe so muche and more muste now be vsed to reforme them so muche time dothe alter the manners of men. (Spenser 1949, 113)

The English have become debased "throughe licentious Conuersing with the Irishe or marryinge and fosteringe with them or lacke of mete nourture" (Spenser 1949, 117). In the View, Irenius claims that the Irish and the Scots have common ancestors, both being derived from the Scythians who arrived first in Ireland and later proceeded into Scotland (Spenser 1949,83$).^{80}$ It is relevant that Pastorella's biological mother Claribell refused to marry a Scot:

Her name was Claribell, whose father hight

The Lord of Many llands, farre renound

For his great riches and his greater might.

He through the wealth, wherein he did abound,

This daughter thought in wedlocke to haue bound

Vnto the Prince of Picteland bordering nere,

But she whose sides before with secret wound

Of loue to Bellamoure empierced were,

By all meanes shund to match with any forrein fere.

(6.12.4.1-9)

Anne Fogarty rightly states that in the View Irenius puts forth "his blueprint for an idealized Ireland which, through carefully executed alterations, has been transformed into a perfect icon of imperial power" (Fogarty 1989, 88). The environment in which Pastorella has been brought up is a symbol of an idealized Ireland of Spenser's imagination, one containing the subjugated Irish. Pastorella typifies what is strongly desired by Irenius: unassimilated inherent nobility. She may therefore be a symbol of the New English colonists who, it is hoped, will not allow themselves to become degenerate as did the settlers of the twelfth century who are chastised by Irenius. 
Although their depiction is informed by the conventions of Greek romance, the Brigants who destroy the peaceful existence of this pastoral idyll show every sign of being Irish rebels:

A lawlesse people, Brigants hight of yore, That neuer vsde to liue by plough nor spade, But fed on spoile and booty, which they made Vpon their neighbours, which did nigh them border, $(6.10 .39 .3-6)^{81}$

The actions of the Brigants against the pastoral community are violent; they "spoyld their houses, and them selues did murder; / And droue away their flocks, with other much disorder" (6.10.39.8-9). Spenser would have been aware of pirates and warriors in the Greek romances of Heliodorus and Longus, but he was living, and writing The Faerie Queene, in an environment where raids upon a neighbour's territory were a common occurrence; the Native Irish around him were available as ever-present models of brigandry. ${ }^{82}$ In The Image of Ireland (1581) John Derricke depicts a cattle raid on the Pale, and his comments on the actions of the Irish rebels are remarkably similar to Spenser's description of the actions of the Brigants: the raiders are denounced as "a packe of prowling mates" who "spoyle, and burne, and beare away, as fitte occasions serue," and, when they have finished their destruction, they "returne backe to the wood, from whence they came" (Moody, Martin \& Byrne 1976, plate 2).$^{83}$ Similarly, in A Brief Note of Ireland, the description of the actions of the Irish rebels in the Munster rebellion led by Tyrone echoes the violent actions of the Brigants:

And going straight vppon the English as they dwelt disparsed before they could assemble themselues spoiled them all, there howses sacked and them selues forced to flie away for safetye, so many as they could catch they hewed and massacred miserablie the rest leaving all behinde them fledd with their wives and Children to such porte townes as were next them . . . (Spenser 1949, 238, lines 122-127)

Furthermore, the description of the Brigants as "Like a sort of hungry dogs" (6.11.17.1) is echoed in A Brief Note of Ireland in the plea that Elizabeth take severe action against Irish rebellion and so give succour to the New English Planters before they become "the pray of dogges" (Spenser 1949, 241, line 222). In the View, Irenius repeatedly characterizes the Irish as lawless thieves, guilty of disorder and destruction. Further evidence that the Brigants are Irish is the description of where they live:

Their dwelling in a little Island was, Couered with shrubby woods, in which no way Appeard for people in nor out to pas, Nor any footing fynde for ouergrowen gras. (6.10.41.6-9)

As we saw in chapter 5, woodland provided protection for the Irish rebel (Derricke's raiders "returne backe to the wood, from whence they came") and established what where virtually no-go areas for the New English colonizers. In "A Booke of Questions and Answars Concerning the Warrs or Rebellions of the Kingdome of Ireland" 
(1597), the woodland is a refuge for the rebels of Leinster who are said to "hide themselues in the day tymes in the mountaines, and glenes, woods \& bogs of the prouince, and quarter themselues in the night or euening to go to seeke victualls of the peacable subiects" (Morgan 1995, 98). In The Faerie Queene Spenser's Brigants have "fed on spoile and booty, which they made / Vpon their neighbours, which did nigh them border" (6.10.39.5-6). Furthermore, as Andrew Hadfield points out, the Brigant's dwelling resembles a crannog, or fortified lake dwelling, as used by Hugh O'Neill in the Nine Years War (Hadfield 1997, 184).

Humphrey Tonkin's remark that the attack of the Brigants "is not simply an attack on the shepherds' way of life, but a frontal assault on the idea of courtesy itself, as symbolized by Pastorella" (Tonkin 1972, 143-44) is even more significant if we understand that for Spenser courtesy was a secular code of behaviour informed by Christian values (Borris 1990, 194). As William Tayler points out, Book 6 "is a pastoral romance in the tradition of Daphnis and Chloe and Sidney's Arcadia" and a "moral allegory" that "offers a panoramic view of manners and morals, spanning the entire range from true courtesy to complete baseness" (Tayler 1964, 103). That the Brigants are antithetical to Christianity as well as courtesy is suggested by their diabolical hide-out_- "vnderneath the ground" in "hollow caues" hidden by "thick shrubs" and consumed by "darknesse dred" (6.10.42.1-5)_recalling the dark cave where Error, the enemy of truth and holiness, dwells in Book 1 (1.1.11-14).

Tonkin notes that the episode is "a kind of infernal parody" (Tonkin 1972, 144) of the pastoral existence whereby the Brigants plunge the "inhabitants of a green and sunlit world, into the wintry darkness of their anti-society beneath the earth" (Tonkin 1972, 143). In the View, as we have seen, Irenius identifies ignorant Irish Catholics as nonChristian (Spenser 1949, 136).

Although the Brigants behave in a manner antithetical to the code of courtesy, they are not immune to its pleasures. When Pastorella is abducted by the Brigants, her beauty triggers the desire of their Captain:

One day as he did all his prisoners vew, With lustfull eyes, beheld that louely guest, Faire Pastorella, whose sad mournefull hew Like the faire Morning clad in misty fog did shew. (6.11.3.6-9)

In the pastoral world, even the barbarians conform to the rules of romantic love: he woos her and she shows him some favour because she fears rape, but she is careful to keep her chastity intact. Her greatest fear is that she will be forced to accept penetration by her enemy, which will render her unworthy of the noble Calidore's love. As a symbol of the supposedly morally superior nature of inherent nobility, she must not allow herself to be penetrated by her social and cultural inferior. The reader's sympathy for Pastorella is elicited to underline the moral correctness of her position and what she embodies. The narrator repeatedly laments her predicament, while the Captaine who is attracted to her is characterized as lustful.

The fact that Pastorella and her people are to be sold as slaves betrays an anxiety about power, ownership, and hierarchal relationships in Ireland. Pastorella manages to gain control of a situation that threatens the chastity upon which her 
social value is predicated. Here, as so often in English colonial writings, colonizer and colonized are positioned within a paradigm of sexual relations. The land as a green-sick virgin ripe for penetration is evident in Raleigh's famous description of Guiana as "a countrey that hath yet her maidenhead" (Raleigh 1596, N4v) and Gernon's description of Ireland (1620) as "a yong wenche that hath the greene sicknes for want of occupying" (Falkiner 1904, 349). What is unusual in the case of Pastorella is an emphasis on the colonizer as resilient virgin on guard against penetration by the colonized Irish, instead of the usual exhortation to the colonizer to penetrate fair Ireland. A similar situation is evident in Shakespeare's The Tempest in Caliban's desire to penetrate the virginal Miranda. As with the abduction of Amoret by Lust in Book 4 the abduction of Pastorella betrays anxiety about miscegenation, particularly the coupling of a 'civilized' woman with an indigenous man and may point to the historical coupling of Hugh O'Neill and Mabel Bagenal, explored in relation to Amoret and Lust in chapter 5. In "The Influence of Spenser's Irish Experiences on The Faerie Queene" M. M. Gray considers that the abduction of Pastorella "suggest[s] the possibility of some real incident of this kind as a source" (Gray 1930, 421).

Pastorella's virtue is demonstrated by reference to her economic worth. The Captaine in The Faerie Queene jealously guards Pastorella and will not allow the merchants to buy her:

To whom the Captaine in full angry wize Made answere, that the Mayd of whom they spake, Was his owne purchase and his onely prize, With which none had to doe, ne ought partake, But he himself, which did that conquest make;

At this point the identification of Pastorella with a specific group becomes problematic because she represents here not only the new colonizer of Ireland but the colonized, that is, the economically desirable potential of the land itself. ${ }^{84}$ Anne Fogarty senses the same apparently contradictory allegorical signification in the View: "If, as Gottfried proposes, one of its possible derivations is 'Irena', the term used for Ireland in The Faerie Queene, then Irenius may be regarded as the voice of the conquered land itself, which raises a plea for its own subjugation" (Fogarty 1989, 89). ${ }^{85}$

Pastorella is economically attractive, despite the sickness she brings on herself in order to avoid the sexual contact that is a consequence of male praise. When the merchants see her, they are struck by her beauty:

The sight of whom, though now decayd and mard, And eke but hardly seene by candle-light, Yet like a Diamond of rich regard, In doubtfull shadow of the darkesome night, With starrie beames about her shining bright, These marchants fixed eyes did so amaze, That what through wonder, and what through delight, A while on her they greedily did gaze, 
And did her greatly like, and did her greatly praize.

(6.11.13.1-9)

Pastorella's apparent sickness has not erased her beauty; despite her trials she is still a valuable commodity and a capital investment. This is especially true if we agree that, at certain points in the allegory, she represents the land of Ireland itself. We saw in chapter 5 that rebellion and unrest in Ireland were often described by colonial commentators as sickness. In Pastorella the language of colonial excavation meets the language of the poetic blazon, which frequently analogized female body parts as precious materials; "the diamond of rich regard" fuses ideas about sexual possession and economic value. ${ }^{86}$

That the Saluage Nation who attack Serena conform to the construction of the Native Irish as savages has been recognised by Gray (1930), Chang (1955) and McNeir (1969). Although Gray stresses the influence of Greek myth he recognizes that the sacrifice of Serena and the abduction of Pastorella show "what the English felt about the Irish rebels" (Gray 1930, 420). Similarly, with reference to the View, Chang draws a parallel between the savages who abduct Pastorella and Serena and Spenser's perception of Irish outlaws (Chang 1955, 129-35). McNeir agrees with Chang that Spenser's principal inspiration for the Saluage Nation was his perception of the Irish outlaws as barbaric (McNeir 1969, 153 note 115). Although Walter Staton claims that the depiction of the Saluage Nation is indebted to Renaissance Italian pastorals, it could be argued that the ritualistic element of the Italian pastorals and the "diuelish ceremonies" (6.8.45.7) of the Saluage Nation's Priest, also suggest the Catholic Mass (Staton 1966, 36-38). Even Williams, who denies that there is an Irish dimension to the Saluage Nation, concedes that "The identification has perhaps a little truth, however, notably that the Irish living at a lower social level than the English are not therefore more virtuous but less" (Williams 1967, 50). Williams is too literal in his reading of the allegory when he claims that "certainly not even Spenser imputed anthropophagy or human sacrifice to the Irish" (Williams $1967,50)$. Spenser need not have believed or claimed that the Irish ate human flesh to have used the notion of cannibalism as an indication of general barbarism with perhaps a hint of the Roman Catholic belief in transubstantiation.

The epithet 'saluage' is used throughout the View with reference to both Ireland and the Irish people and also occurs regularly in The Faerie Queene. Hamilton notes that Spenser refers to Ireland in his dedicatory sonnet to Ormond as the "saluage soyl" (Spenser 1977, 609) and it seems unavoidable that Spenser intends Ireland as "the saluage Iland" in Book 5 (5.11.39.3). Yet not all the 'savage' men in The Faerie Queene are barbaric. Book 6 presents the reader with two very different kinds of savage: the individual Saluage Man, who shows compassion to Calepine and Serena, and the collective Saluage Nation, who molest and attempt to eat Serena. Groups of 'savages' might also be docile and benevolent, like the Saluage Nation who adore Una in Book 1. Although they are described as "A rude, misshapen, monstrous rablement" (1.6.8.7), they are astonished by Una's beauty and worship her for it. The other 'savage man' in The Faerie Queene is the monstrous figure of Lust, discussed in chapter 5.

The gentler feelings of the 'civil' Saluage Man in Book 6 are inherent, not culturally acquired. He "neuer till this houre / Did taste of pittie, neither gentlesse 
knew" (6.4.3.1- 2) but is moved to compassion at Calepine's predicament and, like the shepherds in the Pastorella episode, treats his guests with appropriate courtesy. Spenser leaves the reader in no doubt as to this wild man's origins-"For certes he was borne of noble blood" (6.5.2.7) —and he emphasizes that, despite a gruesome appearance, noble blood will make itself apparent:

For howsoeuer it may grow mis-shapt, Like this wyld man, being vndisciplynd, That to all vertue it may seeme vnapt, Yet will it shew some sparkes of gentle mynd, And at the last breake forth in his owne proper kynd.

Although Spenser is keen to emphasize the inherent nobility of the Saluage Man, which makes him behave with courtesy, he is also interested in his position outside civilization, which demonstrates that nurture has failed nature. Unlike Pastorella, who has retained her innate 'superiority' to her surroundings, the Saluage Man is a hybrid, neither properly civilized nor completely savage.

The advocates of British colonialism attempted to draw up strict ethnic categories: Old English, Native or 'meere' Irish, and New English. That these distinctions could become blurred, as with the Old English, was a source of enormous anxiety. In "'Wildehirissheman': Colonialist Representation in Shakespeare's Henry V', David J. Baker refers to English discomfiture about those who do not conform to the categories created by the colonist: "The hybrid-either the degenerate Englishman or the incompletely assimilated Irishman-could become, for colonial power, a figure of threatening ambiguity" (Baker 1992, 40). As Hadfield and McVeagh point out in their study of British perceptions of Ireland, Hugh O'Neill was such a figure:

O'Neill troubled and enraged English writers not just because of the danger and disruption he caused, nor simply for the audacity of his nearly successful war, but because he was a transgressive and hybrid figure who in many ways resembled them. (Hadfield \& McVeagh 1994, 89)

Although Spenser's Saluage Man is an example of such ambiguity, its threatening aspect has been contained by his inherent nobility, despite the apparent assimilation evident in his appearance. The Old English should, like the Saluage Man, display a manner that sets them apart from the Native Irish, but they do not. For Spenser, degeneration of the inherently noble, something to be feared, is entirely possible. The Saluage Man and, indeed, Pastorella may therefore be emblems of poetic wishfulfilment. If so, then the episodes featuring Pastorella and Serena give us an insight to the anxieties of the settler in the colonial project. Metaphors of sexual violence towards women convey the fear of miscegenation or contamination of the New English by the indigenous Irish.

There are notable similarities between the Brigants who abduct Pastorella, the cannibals who assault Serena, and the mob sent by Grantorto to abduct Flourdelis (5.11.43-65). All are associated with Catholic lawlessness and disorder. Significant parallels can be drawn between the attack on Serena and the degradation of Flourdelis, Burbon's lady, which occurs toward the end of Book 5. 
Although the specific historical relevance of this allegory has been discussed by critics, its meaning in the context of general Catholic rebellious violence, and particularly the depiction of Flourdelis as sexual transgressor, has been largely ignored. ${ }^{87}$ Yet it is significant that the rebellion of France is located in sexual terms and that a political agenda is evident in the fusion of the sexual and the territorial. It is no surprise that Flourdelis suffers aggression not only from the mob who abduct her but also from Artegall, the Protestant representative of English justice in Book 5.

Flourdelis is explicitly associated with France by her name, which refers to the fleur-de-lis, the royal symbol of France. In Book 5, the woman-as-land trope is also evident in Irena (Ireland), whose liberation is the object of Artegall's quest, and Belge (the Low Countries). That France should also be included reveals Spenser's interest in vindicating the justice of Elizabeth's foreign policy. We have seen that, in their rhetoric about Ireland and the New World, Gernon and Raleigh used the woman-as-land trope to construct the land as a virgin ripe for penetration.

When Artegall comes across Burbon and the "rude rout" he is in the company of Sir Sergis. This is significant because prior to this we learn that Sergis has come from Irena (Ireland) to remind Artegall of his promise to "meete her at the saluage llands syde, / And then and there for triall of her right / With her vnrighteous enemy to fight" (5.11.39.3-5). Irena is an idealized personification of the land of Ireland, held in subjection to tyrannical Catholic power, but she also symbolizes Elizabeth as Virgin and rightful ruler of that land. Although Irena is constructed as an innocent victim of Catholic aggression, Flourdelis is blamed for her situation because she has been disloyal to her Protestant champion. Burbon explains her infidelity to Artegall and Sergis:

But sure to me her faith she first did plight, To be my loue, and take me for her Lord, Till that a Tyrant, which Grandtorto hight, With golden giftes and many a guilefull word Entyced her, to him for to accord.

O who may not with gifts and words be tempted?

Sith which she hath me euer since abhord, And to my foe hath guilefully consented:

Ay me, that euer guyle in wemen was inuented.

(5.11.50.1-9)

Flourdelis has been seduced by the same tyrant who holds Irena against her will, the tyrant, of course, being Catholicism or a powerful symbol of it-either Philip of Spain or the Pope himself. Yet the circumstances of Flourdelis's betrayal are not clear. Burbon says that "me she haue forlore" (5.11.49.7), which implies sexual infidelity, yet he qualifies this by saying, "Whether withheld from me by wrongfull might, / Or with her owne good will, I cannot read aright" (5.11.49.8-9). It is clear, to the reader if not to Burbon, that Flourdelis does not want to give herself up to Grantorto entirely. Although Burbon claims that she has been seduced "With golden giftes and many a guilefull word" (5.11.50.4), she resists the force of Grantorto's mob (5.11.44.7-9) which implies that, although she has fallen, she is not beyond redemption. 
Prefiguring the assault on Serena, Flourdelis's clothing is ripped by her keepers: "those villens through their vsage bad / Them fouly rent, and shamefully defaced had" (5.11.60.8-9). ${ }^{88}$ Torn clothes suggest that she has been sexually assaulted which is consistent with her mood when she is rescued: "Her half dismayed they found in doubtfull plight, / As neither glad nor sorie for their sight" (5.11.60.4-5). ${ }^{89}$ When Burbon "with greedie great desyre" rushes at Flourdelis in an attempt to embrace her, she responds with disdain. For this reaction she is condemned by Artegall:

... What foule disgrace is this,

To so faire Ladie, as ye seeme in sight, To blot your beautie, that vnblemisht is, With so foule blame, as breach of faith once plight, Or change of loue for any worlds delight? Is ought on earth so pretious or deare, As prayse and honour?

(5.11.62.1-7)

For Artegall, beauty is an outward manifestation of honour, and, for a woman, honour is located in chastity. By being unfaithful, Flourdelis has ruined her beauty, which before her infidelity was "vnblemisht". She is wholly blamed by Artegall for her predicament, despite her earlier demonstration of resistance:

Why then will ye, fond Dame, attempted bee Vnto a strangers loue so lightly placed, For guiftes of gold, or any worldly glee, To leaue the loue, that ye before embraced, And let your fame with falshood be defaced? Fie on the pelfe, for which good name is sold, And honour with indignitie debased:

Dearer is loue then life, and fame then gold; But dearer then them both, your faith once plighted hold. (5.11.63.1-9)

Like Munera (5.2.9), Flourdelis has accepted gifts of gold, symbolic of the Catholic church's ill-gotten wealth, and she is subjected to Artegall's moralistic rant on the sins of worldly as opposed to spiritual riches. Artegall positions beauty as a signifier of Protestant faithfulness, which has been tainted by association with the Roman Catholic Church. He makes Flourdelis feel ashamed for her sexual treason:

Much was the Ladie in her gentle mind Abasht at his rebuke, that bit her neare, Ne ought to answere thereunto did find; But hanging downe her head with heauie cheare, Stood long amaz'd, as she amated weare. $(5.11 .64 .1-5)^{90}$

Artegall's anger at Flourdelis's sexual infidelity indicates anxiety about Catholic power, which is here depicted as sexual aggression. A similar fear is evident in encounters between Pastorella and the Captaine and Serena and the cannibals. 
Anxiety about power, possession, and the control of land is played out upon the body of a woman. The sympathy urged by the narrator when Pastorella is abducted by the Brigants is also elicited in the episode featuring Serena and the cannibals, although Spenser's use of poetic blazon complicates our response since he lingers excessively on the sexual details of her plight. ${ }^{91}$ Because Flourdelis has been unfaithful, the reader is distanced from her predicament. In this complex pattern of symbolism, woman as sexual Other may at times take precedence over woman as Protestant and/or New English victim.

In Books 5 and 6 of The Faerie Queene three female figures are attacked by 'Catholic' mobs: Flourdelis, Serena and Pastorella. Only the first of these has been assigned a national affiliation by critics. It has not been hitherto proposed that Pastorella and Serena may represent the New English colonist in Ireland, but the narrative subtext I have described suggests that the episodes in which they appear reveal New English fear of Native Irish attack. This is articulated through metaphors of miscegenation and the threat of sexual assault. While both the Pastorella episode and the Serena episode dramatize the threat of penetration, it is only in the latter that we encounter the threat of total consumption. Here is both penetration and ingestion: the former suggests contamination, but the latter brings annihilation. The Serena episode shows two ways the Irish might corrupt the New English: through sexual penetration, which results in miscegenation, and through total loss of identity by annihilation. In Spenser's worst nightmare, the English are swallowed up by the Irish.

\section{Chapter 8}

Mutabilitie and Degeneration in The Faerie Queene

In Book 7 of The Faerie Queene Spenser writes about the rebellion of Mutabilitie against Jove, her appeal to Nature, and Nature's verdict. It is not known exactly when Spenser composed these cantos but they were first published after his 
death, with Books 1-4 of The Faerie Queene in the 1609 folio edition. The cantos are concerned with rebellion, change, and degeneration on a cosmic scale. The subject of the cantos, mutability, is a central concern throughout Spenser's work and the cantos reveal anxieties about local degeneration and gender projected onto the figure of Mutabilitie and expressed as cosmic disorder. Within the story of Mutabilitie's rebellion is the rebellion of Molanna against Diana which will be discussed later in this chapter. The introduction to this book explored anxieties about rebellion, gender, and governance present in the "Supplication" (Anon. 1995) and the View. The main chapters explored these anxieties in The Faerie Queene. Although Spenser may not have intended it as such, the incomplete Book 7 functions as an appropriate coda for the poem because it concentrates the anxieties that suffuse the work. As elsewhere in Spenser's poem, his concerns about mutability are registered via a young female personification which recalls the degeneration provoked by malevolent female figures throughout the poem and by Irish women in the View and the "Supplication". As we have seen in the View Irenius's greatest anxiety is the degeneration of the Old English settlers who have become like the Irish. The character of Mutabilitie embodies Spenser's abhorrence of the changes that had already taken place in Ireland and his fear of future decline.

In the opening stanza of Book 7 we learn that Mutabilitie, like Fortune, enjoys her cruel sport at the expense of mankind, ${ }^{92}$ and is the source of degeneration and rebellion:

What man that sees the euer-whirling wheele

Of Change, the which all mortall things doth sway,

But that thereby doth find, and plainly play

Her cruell sports, to many mens decay?

Which that to all may better yet appeare,

I will rehearse that whylome I heard say,

How she at first her selfe began to reare,

Gainst all the Gods, an th'empire sought from them to beare.

(7.6.1.1-9)

Mutabilitie has risen in rebellion against the empire of the gods, an occurrence which parallels Irish rebellion against the governance of Elizabeth as God's representative on earth. As in The Faerie Queene, the View, and the "Supplication" ancestry determines character. Like Argante, Mutabilitie is the daughter of a Titan, a lineage which provokes a thematic association of aggression and rebellion. Similarly both figures have 'perverted' nature: Argante by her incestuous and bestial sexual practices and Mutabilite by her destruction of nature's laws and hierarchies (7.6.5.24). The implicit comparison of Mutabilitie with Argante also identifies her with Argante's lust, a sexual degeneracy associated with the malevolent female figures who represent the degeneracy of the Roman Catholic Church throughout the poem. In "Fraile Woman, Foolish Gerle: Misogyny in Spenser's Mutabilitie Cantos", Richard J. Berleth rightly points out that the narrator details Mutabilitie's lineage because "her 'Right' derives from the demonic, antirational forces of earth ascribed by misogynists to the feminine" (Berleth 1995, 44). Mutabilitie is "an allegorical projection of mythicized female nature" and is considered "too rebellious, proud, vain, inconstant, ignorant, and thoughtless to be trusted with power". The female is associated with disorder and so she is "a door opening onto chaos" (Berleth 1995, 53). Ironically, 
although she embodies degeneration and decay she also "remains vital to the perpetuation of life" which may, given the chastity of Cynthia/Diana, signal anxiety about female fecundity (Berleth 1995, 40-44).

Mutabilitie has inverted the positive aspects of existence that were in place before her intervention, bringing about degeneration, loss, and moral corruption:

For, she the face of earthly things so changed,

That all which Nature had establisht first In good estate, and in meet order ranged, She did pervert, and all their statutes burst:

And all the worlds faire frame (which none yet durst

Of Gods or men to alter or misguide)

She alter'd quite, and made them al accurst

That God had blest; and did at first prouide

In that still happy state for euer to abide.

(7.6.5.1-9)

She has destroyed hierarchies which implies not only her unwelcome intrusion into the natural world but also her influence in the disruption of social order, specifically social order in Ireland. She is responsible for negative change which is referred to throughout the View as degeneration. The OED records the adjective 'degenerate' as follows: "Having lost the qualities proper to the race or kind; having declined from a higher to a lower type; hence, declined in character or qualities; debased, degraded" (adj. 1) and perhaps most pertinently records the verb as "To lose, or become deficient in, the qualities proper to the race or kind; to fall away from ancestral virtue or excellence; hence (more generally), to decline in character or qualities, become of a lower type" (intr. 1). Significantly, in the View Irenius tells Eudoxus that the Old English "have degendred from theire antiente dignities [and] are now growne as Irishe as Ohanlans breech, (as the proverbe theare is,)" (Spenser 1949, 117). To see the relevance of the rebellion of Mutabilitie against Cynthia and Molanna against Diana, it is worth recalling the preoccupation with mutability as degeneration throughout the poem.

In The Faerie Queene the degeneration of the landscape is a sign of the degeneration of the moral universe. ${ }^{93}$ In Book 1 Una's land, Eden, is in the grip of the dragon, an allusion to humankind's state of sin after the fall of Eden. Una and her parents enjoyed an innocent life until the dragon came: "And all the world in their subiection held; / Till that infernall feend with foule vprore / Forewasted all their land, and them expeld" (1.1.5.6-8). There is a strong sense of blind nostalgia throughout The Faerie Queene: the narrator harks back to a previous era, depicted as a moral, constant place. The degeneration of the world is alluded to in every book of the poem. In Book 1 the narrator relates that "th'antique world excess and pride did hate; / Such proud luxurious pompe is swollen vp but late" (1.12.14.8-9); a statement which evokes not only the antique world but the manifestations of Roman Catholic decadence that pervade the poem, evident for example in Lucifera in the House of Pride (1.4) and Malecasta in her castle (3.1). Excess is personified in Acrasia's Bower of Bliss (2.12.55-57) and all malevolent figures in the poem are guilty of the sin of pride. In Book 2 the narrator claims that pride and lust have replaced the benevolence of the golden age (2.7.16). As we have already seen, the Irish are 
accused of being licentious in the View, the "Supplication", and other contemporary English writings on Ireland. For the narrator, the old world is associated with youth, goodness, and "vnreproued truth" (2.7.16) which echoes the appearance and role of Una as a representative of Protestant truth in Book 1. Of course lust is a dominant characteristic of the malevolent figures who represent the Catholic enemy in The Faerie Queene and is a vice associated with rebellion and degeneration in the View and the "Supplication".

As we saw earlier, allusion to the Catholic enemy is made via the pagan knights who permeate the landscape of Fairyland. Such figures are denounced in the narrator's praise of the antique world in Book 3:

O goodly vsage of those antique times, In which the sword was seruant vnto right; When not for malice and contentious crimes, But all for praise, and proofe of manly might, The martiall brood accustomed to fight: Then honour was the meed of victorie, And yet the vanquished had no despight: Let later age that noble vse enuie, Vile rancour to auoid, and cruell surquedrie. (3.1.13.1-9)

While the heroes of the poem are virtuous they are challenged by knights whose only motivation is "malice" and who commit "contentious crimes" against honourable knights and ladies. The notion of noble blood as an indicator of civility in The Faerie Queene finds a parallel in the View when Irenius complains that English blood has become tainted and so the Old English have grown degenerate by close contact with the savage Irish: "the Englishe that weare are now muche more Lawles and Licentious then the verie wilde Irishe" (Spenser 1949, 113). The same anxiety about miscegenation is evident in the "Supplication". Temperance is rare but so are other virtues that were in plentiful supply in the golden world: "But antique age yet in the infancie / Of time, did liue then like an innocent" (4.8.30.1-2). As with Una and her parents in Eden before the oppression of the dragon, life in the ancient world is again said to have been "innocent", suggesting sexual purity and political naivety.

The virtues that are central to The Faerie Queene were also dominant in the ancient world: temperance (the ruling virtue of Book 2), truth (personified in Una in Book 1), and chastity (embodied in Belphoebe in Books 3 and 4, and Britomart in Books 3, 4 and 5). Irenius in the View and the speaker in the "Supplication" claim that these virtues are lacking in the Irish. In the proem to Book 5, the book which contains the most overt allusions to Ireland, the antique world is presented by the narrator as young, fresh, and virtuous. Since then the world has become disordered and is steadily getting worse: "Me seemes the world is runne quite out of square, I From the first point of his appointed sourse, / And being once amisse growes daily wourse and wourse" (5.proem.1.7-9). This sense of global disintegration masks a localized anxiety about problems in Ireland alluded to throughout the poem. Given that Book 5 contains an iron man as an instrument of torture and death it is ironic that the narrator should complain that men "Of earthly mould, and form'd of flesh and bone, I Are now transformed into hardest stone" (5.proem. 2.4-5). Irenius also rejects 
compassion in the View when he insists that in order to bring about the successful Reformation of Ireland there should be no remorse or compassion shown to its people (Spenser 1949, 163). Guile, not present in the ancient world, is a force to be reckoned with in the post-mutability world of The Faerie Queene. His appearance bears remarkable resemblance to the Irish rebel and the narrator effectively describes the Irish glib and mantle: "And long curld locks, that downe his shoulders shagged, / And on his backe an vncouth vestiment" (5.9.10.6-7). Guile is elusive and a shape-changer, like Duessa and other malevolent figures who manipulate perceptions in The Faerie Queene.

The narrator depicts the ancient world as one of peaceful co-habitation between natural enemies: "The Lyon there did with the Lambe consort, / And eke the Doue sate by the Faulcons side" (4.8.31.1-2). Since then, however, the world has become dissolute:

Then beautie, which was made to represent The great Creatours owne resemblance bright, Vnto abuse of lawlesse lust was lent, And made the baite of bestiall delight: Then faire grew foule, and foule grew faire in sight, And that which wont to vanquish God and man, Was made the vassall of the victors might; Then did her glorious flowre wex dead and wan, Despisd and troden downe of all that ouerran. (4.8.32.1-9)

The False Una and the False Florimell are malevolent doubles of beautiful women and demonstrate that beauty can be an illusion which masks degeneracy. The degeneration of beauty is also a degeneration of chastity: the "glorious flowre" is now "despisd and troden down", implying the loss of valuable virginity and the victory of sexual promiscuity. Duessa is an example of beauty lent to "lawlesse lust" because she makes herself "the baite of bestiall delight", arousing the lust of malevolent knights and, like the Irish women who are accused of seduction in the View and the "Supplication", tricking good knights by sexual entrapment. She is thus the enemy of the chaste Belphoebe and Britomart. Not only does she manage to alter her own horrible form to one of superficial beauty but she also attacks true beauty in others: like the Native Irish in the View she makes her moral 'superiors' degenerate. This is most evident in her imposition of a horrible form upon the true beauty of Fradubio's lady, Fraelissa (1.2.34-39). Archimago shows that he is also capable of changing shape when he imposes the beautiful form of Una upon a male spright:

[Archimago] all this while with charmes and hidden artes,

Had made a Lady of that other Spright,

And fram'd of liquid ayre her tender partes

So liuely, and so like in all mens sight, That weaker sence it could haue rauisht quight: (1.1.45.1-5)

The imposter ravishes the 'weaker sense' of Redcross for he believes the lascivious creation to be Una herself: 
And she her selfe of beautie soueraigne Queene,

Faire Venus seemde vnto his bed to bring

Her, whom he waking euermore did weene

To be the chastest flowre, that ay did spring

(1.1.48.1-4)

The key word is "seemde", a signal throughout the poem when a beautiful appearance masks a morally corrupt interior. The False Florimell, constructed by a witch in Book 3, is an echo of the degenerate Una created by Archimago. Like Archimago's creation, it is enlivened by a male sprite and is referred to by the narrator as an "Idol" (3.8.11.2), a term which identifies it with Roman Catholicism. As we have already seen, the Irish are constantly denounced as idolatrous in the "Supplication". The False Florimell is demonic and manages to fool not only the witch's son but also morally upright knights who are deceived because they have let down their guard and so succumbed to beauty without substance. The seduction of good knights by degenerate doubles of good women suggests a fear of miscegenation and the confusion of not being able to easily identify the enemy because those who appear to be English are Irish underneath or within. As we shall see later, this anxiety is evident in the description of the beauty and stature of Mutabilitie.

In the proem to Book 6 the narrator claims that the courtesy present in the ancient world is now found wanting: although the present age "doe plenteous seeme" it is "all but fayned showes . . . / Which carry colours faire, that feeble eies misdeeme" (6.proem.4.6-9). The danger of an enemy who appears to be benevolent is a central concept of the poem: the enemies of Protestant knights lurk behind attractive appearances but, if the knight should let his guard down, then danger is imminent. The apparent courtesy of the present age is fraudulent:

But in the triall of true curtesie, Its now so farre from that, which then it was, That it indeed is nought but forgerie, Fashion'd to please the eies of them, that pas, Which see not perfect things but in a glas: Yet is that glasse so gay, that it can blynd The wisest sight, to thinke gold that is bras. (6.proem.5.1-7) ${ }^{94}$

The "forgerie" that is "fashion'd to please the eies" describes Duessa, the False Una, and the False Florimell. All three figures are representative of counterfeit beauty because they are malign beings in a pleasing disguise. Duessa is somewhat autonomous, although she pairs up with various malevolent figures throughout the poem, but the latter two male sprites are 'fashioned' by malevolent figures: the False Una by Archimago (1.1.45-46), and the False Florimell by a witch (3.8.5-9). Both creators are associated with the Roman Catholic church by their use of incantations, spells, and trickery to conjure up illusions. That the false doubles created by the witch and Archimago are males masquerading as females reveals anxieties about gender: the figures are doubly Other, sexually as well as religiously 'foreign'. 
In their support for virtue and attacks on corruption, the knights of The Faerie Queene constantly expose themselves to the dangers of moral degeneration. An extreme and powerful symbol of such degeneration is Grille, happy to be transformed into a hog by Acrasia, the Catholic witch and whore. We have already seen that sexually promiscuous women such as Acrasia are condemned throughout The Faerie Queene: these female figures who embody the power of Catholicism can, via sex, bring about the degeneration of loyal Protestant knights. Similarly in the View and in the "Supplication" Irish women are accused of sexual promiscuity and are blamed for the degeneration of English men. If sexually promiscuous women lead men astray, then chaste women guide them through dangerous situations. In Book 1 Una warns Redcross of the danger of the Wandering Wood (1.1.12). Redcross attempts to counter her caution with an appeal to reason: "Ah Ladie (said he) shame were to reuoke / The forward footing for an hidden shade: / Vertue giues her selfe light, through darkenesse for to wade" (1.1.12.7-9) but Una realizes that Redcross's naive trust in virtue is misplaced if the virtue is not accompanied by temperance, the dominant virtue in Book 2 and a constituent of all other virtues. ${ }^{95}$ She warns him again and offers her experience and wisdom against his haste (1.1.13). The text suggests that Redcross still has a long way to go if he is to achieve the moral excellence of the virtue he represents:

But full of fire and greedy hardiment,

The youthfull knight could not for ought be staide,

But forth vnto the darksome hole he went,

And looked in:

(1.1.14.1-4)

He succeeds in his battle against Error but not without the encouragement of Una "Now Sir knight, shew what ye bee, / Add faith vnto your force, and be not faint: I Strangle her, else she sure will strangle thee" (1.1.19.2-4). This lack of judgement and failure to perceive 'Truth' leads to more error when he believes the sexually promiscuous Duessa to be chaste (1.2.13-27). Having abandoned Una, his pledge to Duessa is a serious lapse (1.2.27). Redcross's encounter with Duessa reveals his inability to read the signs of proper virtue, and his gullibility in allowing himself to be seduced by her appearance and her lies. It is Una who is responsible for his spiritual healing for it is she who saves him from the despair of suicide, reminds him of his quest to kill the dragon, and brings him to the House of Holiness (1.10). Fradubio, a victim of Duessa's seduction and transformed by her into a living tree, warns Redcross that he is in danger (1.2.31.4-6) but Redcross is not sufficiently alert to the guile of Duessa and so leaves himself vulnerable to seduction. The ever present threat of seduction by Duessa reveals anxiety about political, ethnic, and religious as well as sexual degeneration. We have seen that throughout The Faerie Queene and the View Catholic seduction is figured in sexual terms and here Duessa, the whore, represents the supposed duplicity of the Roman Catholic Church.

Throughout the poem, faithful and honourable knights are juxtaposed with those knights who have allowed themselves to be seduced and so have strayed from the path of righteousness. These degenerate knights appear to be a comment upon the fallen class of the Old English in Ireland and an admonition to the new settlers to remain loyal to England and the Protestant religion. When Redcross is most vulnerable, being led by Duessa to the House of Pride, the narrator warns the young 
knight to be faithful, ostensibly to his lady but actually to what she (and Elizabeth: every good Protestant knight's lady) represents, the Protestant faith:

Young knight, what euer that dost armes professe, And through long labours huntest after fame, Beware of fraud, beware of ficklenesse, In choice, and change of thy deare loued Dame, Least thou of her beleeue too lightly blame, And rash misweening doe thy hart remoue: For vnto knight there is no greater shame, Then lightnesse and inconstancie in loue; That doth this Redcrosse knights ensample plainly proue. (1.4.1.1-9)

The narrator warns against mutability, against inconstancy, and again political and religious loyalty is expressed in terms of sexual fidelity. Redcross represents Holiness but as Saint George he also represents England which dictates that he must adhere to Protestantism. We have seen in chapters 2 and 3 that the role of the whorish witch is transferred from Duessa in Book 1 to Acrasia in Book 2 and that both figures seduce and make degenerate their victims. When Amavia finds her knight Mordant he cannot recognize her, nor can he perceive his own degeneracy (2.1.54). Similarly Verdant has forgotten his noble origins and become degenerate (2.12.80). Military might and honour, central aspects of knighthood, have been defeated by lust.

In The Faerie Queene all good knights are at some time exposed to the dangers of moral degeneration but only some fall victim to it. Many of them experience nearmisses and these situations usually occur when they have allowed themselves to be distracted by the beauty of a malevolent woman. Others, like Artegall, experience temporary degeneration. Similarly Guyon, on his approach to Acrasia's Bower of Bliss, is exposed to the danger of moral debasement by beautiful but deadly females: the nameless maiden who appeals for help (2.12.27-29); the mermaids who beckon him (2.12.32-35); and the bathing damsels (2.12.63-69). They attempt moral degeneration via lust but he is led away from all by the Palmer. Like Redcross upon entering Error's den, Guyon needs guidance so as to avoid these dangers and so be prepared for his ultimate battle with evil.

As well as good knights who fall into temporary degeneracy and those who are momentarily in danger of degeneration there are those knights who are wholly debased. These figures are almost always referred to as 'pagan' and, often being overtly lustful, are coupled with sexually promiscuous female figures. That they are knights implies a noble origin, but that they are degenerate reveals a falling away from nobility: they have "lost the qualities proper to the race or kind; having declined from a higher to a lower type; hence, declined in character or qualities; debased, degraded" (OED degenerate adj. 1). They have become deficient in those qualities that are required to be a knight and thus as 'pagan knights' they embody an apparent contradiction. They share this noble origin and subsequent degeneracy with the Old English in Ireland who, by integration with the Native Irish, have become ignoble. This lack is most evident in the three pagan knights who are brothers: Sansfoy (without faith); Sansjoy (without joy); and Sansloy (without law). Of 
particular significance are those brothers who lack the attributes of faith and law, the same lack perceived by the New English in the descendants of the twelfth-century settlers. It is fitting that Sansfoy, who represents a lack of Protestant faith and so by implication adheres to Roman Catholicism, should accompany Duessa, who resembles the Whore of Babylon (1.2.12-14). It is also fitting that Sansfoy, given his lack of faith, should be defeated by the Knight of Holiness (1.2.15-19). The same irony and Irish Catholic dimension is evident when Una, a proxy of Elizabeth and a symbol of truth and chastity, is in danger from lawlessness in the shape of Sansloy, and is rescued and worshipped by a benign "Saluage Nation", an enthusiastic audience for her teachings who bear resemblance to the Native Irish who lurk in the Irish woodlands (1.6.2-19).

A strong Irish Catholic element is also present in the depiction of the malevolent knight Ferraugh who first appears when he challenges Braggadocchio to give up the False Florimell (3.8.16). Ferraugh believes her to be the real Florimell and in this way he is associated with others who believe the "idole" to be "faire" (3.8.11.2). This erroneous faith in falsehood is a concept that runs throughout the poem and is part of its wider context that unites falsehood with Catholicism. Moreover, Ferraugh is described as a "lustie knight" (4.2.4.2), an epithet that carries associations of sexual desire as well as liveliness and health (OED lusty sb. 1, 4, 5). Ferraugh is associated with the supposed corruption of the Roman Catholic Church but also carries strong associations of the Celts as barbarians. In the View Irenius states that 'Ferragh' is a Gaelic war cry

And hearein allso lyethe open another verye manifest profe that the Irishe be Scithes [Scythians] or Scotts for in all their incounters thei vse one verye Comon worde Cryinge Farragh ferragh, which is a Scottishe worde to wete the name of one of the firste kinges of Scotlande Called Ferragus or Fergus, which foughte againste the Pictes As ye maye reade in Buckanan de Rebus Scoticis But as others write it was longe before, that the name of theire Chief Captaine vnder whome they foughte againste the Africanes the which was then so fortonate vnto them that ever sithence they haue vsed to Call vppon his name in theire Battells. (Spenser 1949, 104)

As in The Faerie Queene where spiritual degeneration is presented as a forgetting of honour and puissance, so in the View the degeneration of the Old English is presented as a kind of socio-political, cultural amnesia. Irenius informs Eudoxus that in the time of St Leger as Lord Deputy the Native Irish and Old English accepted the sovereignty and laws of Henry the Eighth ${ }^{96}$ but since then have forgotten their obligations:

they shoulde haue byne reduced to perpetuall Civilytie and Contayned in Continvall dewtye But what bootes it to breake a Colte And to let him streighte rune loose at random, so weare this people at firste well handeled and wiselye broughte to acknowledge Alleigiance to the Kinges of Englande, but beinge straighte left vnto themselves and theire owne inordinate life and manners they eftsones forgote what before they weare taughte and soe sone as they weare out of sighte by themselves shoke of theire bridles and begane to Colte anewe more licentiouslye then before// (Spenser 1949, 49) 
Fitzpatrick, Joan. 2000b. Irish Demons: English Writings on Ireland, the Irish and Gender By Spenser and His Contemporaries. Lanham. University Press of America.

It comes as little surprise that, given their barbarous origins, the Native Irish should shake off the yoke of English civility but it is a great source of anxiety that the Old English should 'forget' their cultural superiority:

and is it possible that an Englisheman broughte vp naturallye in suche swete Civilytie as Englande affordes can finde suche likinge in that barbarous rudenes that he shoulde forgett his owne nature and forgoe his owne nacion? howe maie this be? or what I praye youe maye be the Cause heareof? (Spenser 1949, 96)

Grille, like the Old English, has "forgot the excellence / Of his creation" (2.12.87.2-3), a reference not only to his humanity but to his supposedly superior social status before seduction by Acrasia. 'Englishness' is forgotten and thus identity as a civil Englishman obliterated.

Part of the process by which English identity is cancelled and Irishness adopted is in naming: some of the Old English, says Irenius, "haue quite shaken of theire Englishe names and put on Irishe that they mighte be alltogeather Irishe" (Spenser 1949, 115). Eudoxus is incredulous, a technique used by Spenser to emphasis how unacceptable these Irish influences are:

Is it possible that anye shoulde soe far growe out of frame that they shoulde in so shorte space quite forgett theire Countrie and theire owne names that is a moste daungerous Lethargie muche worse then that of messala Corvinus whoe beinge a moste learned man thorowe sicknes forgott his owne name . . . (Spenser 1949, 115)

The influence of the Irish is presented as a sickness and a seduction which brings about lethargy and cultural amnesia. The adoption of Irish ways is viewed as disloyalty to England and considered so unnatural that it is compared to violence against a mother by ungrateful children: "Coulde they euer Conceaue anye suche divillishe dislike of theire owne naturall Contries as that they woulde be ashamed of her name and bite at the dug from which they sucked liffe" (Spenser 1949, 116). At the same time, Irenius claims that Irish women are the instigators of degeneration and the Old English have been infected with the breast milk of the Irish nurse (Spenser 1949, 119). The breast feeding metaphor, discussed in previous chapters, is also evident in the Mutabilitie Cantos where the narrator laments "O pittious worke of MVTABILITIE! / By which, we all are subiect to that curse, / And death in stead of life haue sucked from our Nurse" (7.6.6.7-9). In his list of those English who have grown degenerate and changed their names from English to Irish Irenius gives examples of those he considers to be the worst:

the Lo. [lord] Bremingham, whoe beinge the moste anciente Baron I thinke in Englande, is now waxen the moste Salvage Irishe naminge himselfe Irishlike, maccorishe. and the other is the great mortimer whoe forgettinge how greate he was once in Englande or Englishe at all is nowe become the most barbarous of them all and is Called macnemarra; and not muche better then he, is the olde Lo Courcie whoe havinge lewdlye wasted all the Landes and seigniories that he had and aliened them vnto the Irishe is himselfe also now growen quite Irishe. (Spenser 1949, 118)

Mortimer has forgotten his former excellence to the same extent that he has embraced Irish barbarity. 
Another indicator of English identity consumed by Irishness and thus made degenerate is clothing. Irenius laments the fact that a law introduced in 1537 by Henry 8 against the wearing of Irish apparel is not enforced. ${ }^{97}$ Eudoxus agrees that it is an important law: "for mens Apparell is Comonlye made accordinge to theire Condicions and theire Condicons are often times gouerned by theire garmentes" (Spenser 1949, 121). Eudoxus believes that clothing can bring about a change in character and illustrates this conviction with a classical reference:

Therefore it is written by Aristotle that when Cirus had ouercome the Lidians that weare a warlike nacion and devised to bringe them to a more peacable liffe he Chaunged theire Apparrell and musicke And in steade of theire shorte warlike Coate cloathed them in longe garmentes like weomen and in steade of theire warlike musicke appointed to them certaine Lascivious layes and loose gigs by which in shorte space theire mindes weare so mollified and abated that they forgate theire former firesnes [fierceness] and became moste tender and effeminate wheareby it appeareth that theare is not a litle in the garment to the fashioninge of the mynde and Condicions (Spenser 1949, 121)

That Eudoxus should use an example which demonstrates the power of clothing to make men effeminate is significant when we consider the case of Artegall, dressed up in women's clothes by the masculine Radigund (5.5.20.1-9). The wilful adoption of Irish clothing by the Old English in Ireland is recast in The Faerie Queene as a punishment. For allowing himself to be seduced by the beauty of a malevolent woman Artegall loses the signs of knighthood and is forced to wear the 'foreign' clothing of the sexual Other. In the View the wearing of the Irish mantle is particularly criticized for it is used by the rebel and the thief as a means of concealment (Spenser 1949, 100-01). Irenius claims that when it is worn by Irish women it indicates their promiscuity for they use it to conceal sexual acts and the pregnancy that results: "And when she hathe filled her vessell vnder it she may hide bothe her burden and her blame" (Spenser 1949, 101). Like Artegall, Verdant, although seemingly unaware of his shame, is stripped of the signs of knighthood and lounges lazily in the arms of Acrasia (2.12.80). The abandonment of knightly accoutrements is also evident in the story of Burbon who, in trying to rescue his lady Flourdelis from a "rude rout", has been forced to throw away his shield (5.11.43-65). This action is denounced by both the narrator and Artegall as shameful (5.11.46; 5.11.52). The shield is symbolic of honour and to abandon it, warns Artegall, is ignoble:

Hard is the case, the which ye doe complaine;

Yet not so hard (for nought so hard may light,

That it to such a streight mote you constraine)

As to abandon, that which doth containe

Your honours stile, that is your warlike shield.

All perill ought be lesse, and lesse all paine

Then losse of fame in disauentrous field;

Dye rather, then doe ought, that mote dishonour yield.

(5.11.55.2-9)

When Burbon explains that the abandonment of his shield was a politic manoeuvre, Artegall denounces dissemblance and urges truth: "Knights ought be true, and truth is one in all: / Of all things to dissemble fouly may befall" (5.11.56.8-9). This recalls 
the significance of Una as a symbol of the one true religion of Protestantism and a representative of Elizabeth. Critics agree that the Burbon episode is a thinly veiled allegory of the actions of Henri of Navarre who renounced his Protestant faith and converted to Catholicism in order to rule Paris but it also contains echoes of the situation in Ireland that incensed Spenser: in rejecting their 'Englishness' the Old English have effectively thrown away their shields.

To forget one's English culture or to privilege Irish culture over English is severely denounced, explicitly in the View and via allegory in The Faerie Queene. Conversely, to forget Irish culture is positively encouraged. Irenius tells Eudoxus that the imposition of surnames, as occurred during the reign of Edward the Fourth, will break the power of the Gaelic septs:

from thenceforthe eache one shoulde take vnto him selfe a seuerall surname ether of his trade and facultye or of some qualitye of his bodie or minde, or of the place wheare he dwelte, so as euerie one should be distinguished from thother, or from the most parte, wherby they shall not onelye not depende vppon the heade of theire septe as now they doe but allso shall in shorte time learne quite to forgett his Irish nacion. And hearewithall woulde I allsoe wishe all the Oes and the mackes which the heades of the septes haue taken to theire names to be vtterlye forbidden and extinguished ... . (Spenser 1949, 214-15)

This suggestion by Irenius conveys just how important he regards language and naming to be in Ireland. He recognises that the strength of the Irish lies in the sept with its sense of group loyalty and that the best way to control the Irish is by taking the defence of the group from them. The imposition of Protestant individuality via English law will make rebellion more difficult and, if successful, destroy Irishness itself: a kind of cultural genocide is intended. Spenser's ominous recommendation that "the Oes and the Mackes" be "vtterlye forbidden and extinguished" recalls the policy of annihilation via starvation that he advocates earlier in his tract (Spenser 1949, 156-59).

The imaginative presence of Elizabeth 1 pervades The Faerie Queene in its title and in the characters of Gloriana, Belphoebe, Astraea, Una, Mercilla, and as aspects of Britomart, Radigund, Alma, Medina, Florimell, and Irena. Elizabeth 1 is also present in the figures of Cynthia and Diana in the Mutabilitie Cantos. Cynthia was closely associated with Elizabeth (for example it was Raleigh's name for her in his poem "Ocean to Cynthia") ${ }^{98}$ and she was often referred to as Diana. In his Letter to Raleigh, Spenser writes that the figure of Elizabeth is evident in the persons of the Faerie Queene and Belphoebe, and is fashioned "according to youre owne excellent conceipt of Cynthia, (Phoebe and Cynthia being both names of Diana)" (Spenser $1977,737)$. Critics agree that these figures were used in honour of the queen. Frances Yates notes that "the goddess of the moon under various names-Diana, Cynthia, Belphoebe-is the most popular of all the figures employed by Elizabeth's adorers" (Yates 1947, 72), and Helen Hackett concurs that "one of the most common images of Elizabeth in the last fifteen years or so of her reign was that of the moongoddess, Cynthia or Diana" (Hackett 1995, 174). As Yates points out "the moon is the symbol of empire, and the sun of papacy" and, in the context of Elizabeth and Protestantism, "The virgin of imperial reform who withstood the claims of the papacy might therefore well become a chaste moon-goddess shedding the beams of pure 
religion from her royal throne" (Yates 1947, 72). Those who rebel against the moon goddess can therefore presumably be associated with the papacy. Yet the rebels may not be the only problem that presents itself. Although comparing Elizabeth to Diana, the beautiful and chaste goddess of the moon and of hunting, can be read as a form of flattery it might also constitute criticism of the queen. Andrew Hadfield detects an attack on the queen's policies and her ageing, virginal state: "Cynthia is described as never standing still, a double-edged reference to Elizabeth's inconstant policies and the mutability of her own body, which had been beyond childbearing age since the 1580s, leaving the succession uncertain" (Hadfield 1997, 189). In the Mutabilitie Cantos the threat to the representatives of Elizabeth (Cynthia and Diana) presents a most thinly disguised warning to the queen of the consequences of her personal decisions and her policy on Ireland.

The story of Mutabilitie's attempted displacement of Cynthia and the inset story of Molanna's betrayal of Diana posit rebellious and disloyal figures against Elizabeth and might signify rebellion against the English crown in Ireland. As we have seen, Mutabilite's lineage determines her rebellion and that she is an embodiment of change as degeneration. It also determines the pride which provokes her challenge to the gods: she is "fraught with pride and impudence" (7.6.25.2). The degeneration of the world, lamented by the narrator in the proem to Book 5 of The Faerie Queene, is expanded upon in the story of Mutabilitie's rebellion where anxiety and confusion felt about local change and degeneration are expressed in terms of cosmic change, that is, the alteration in the heavens. It is significant that Mutabilitie has demolished not only the laws of nature "But eke of lustice, and of Policie" (7.6.6.2). It is the responsibility of Artegall and Talus in Book 5 to put those laws back into place. There are subtle but significant indications in the text that Mutabilitie's attempt to oust Cynthia from her throne carries allusions to rebellion in Ireland: Mutabilitie threatens violence against Cynthia (Elizabeth) "And there-with lifting vp her golden wand, I Threatned to strike her if she did with-stand" (7.6.13.4-5). Additionally, she wears an "vncouth" habit (7.6.13.9), an epithet glossed by Hamilton as "strange, wild, expressing the state of intemperance into which Guyon is led [by Archimago]" (Spenser 1977, 174). The word "vncouth" is also used to describe the arrested development of the Old English in the View (Spenser 1949, 118) and of Archimago and Maleger in Book 2 of The Faerie Queene (2.1.8.2; 2.11.27.5). Both these figures represent the Irish Catholic Other, Maleger specifically the Gaelic Irish rebel. A further association between Archimago and Mutabilitie is evident in Jove's instruction to Mercury:

Eftsoones the sonne of Maia forth he sent Downe to the Circle of the Moone, to knowe The cause of this so strange astonishment, And why shee did her wonted course forslowe; And if that any were on earth belowe That did with charmes or Magick her molest, (7.6.16.1-6)

Throughout The Faerie Queene 'charmes and magick' are associated with Roman Catholicism and its supposed links with sorcery. As we have seen, practitioners of the black arts such as Acrasia and Duessa are described in terms of the dangers of 
Catholic seduction and what was perceived by some Protestants to be its superstitious trappings.

The danger of seduction by a beautiful but malevolent woman is evident in the description of the beauty and stature of Mutabilitie:

Whil'st she thus spake, the Gods that gaue good eare

To her bold words, and marked well her grace,

Beeing of stature tall as any there

Of all the Gods, and beautifull of face,

As any of the Goddesses in place,

Stood all astonied, like a sort of Steeres;

Mongst whom, some beast of strange and forraine race,

Vnwares is chaunc't, far straying from his peeres:

So did their ghastly gaze bewray their hidden feares.

(7.6.28.1-9)

She resembles her enemies but has an alien nature for she is "of strange and forraine race", a comparison recalling the emphasis on the Irish as strange and savage by early modern English writers. Spenser leaves the reader in no doubt about the power of female beauty for even Jove weakens at the sight of Mutabilitie:

But, when he looked on her louely face, In which, faire beames of beauty did appeare, That could the greatest wrath soone turne to grace (Such sway doth beauty euen in Heauen beare)

He staide his hand: and hauing chang'd his cheare, He thus againe in milder wise began;

(7.6.31.1-6)

Like Duessa and Acrasia, the whorish witches who dominate books 1 and 2 of the poem, Mutabilitie's physical appearance allows her to manipulate others.

Mutabilitie's chastity is also in question for she embodies not only change as degeneration but also change as inconstancy, which carries connotations of sexual promiscuity (OED mutability sb. 1 "Disposition to change, variableness, inconstancy").

The stress on the lineage of Mutabilitie and her rebellion against the empire of the gods suggests rebellion against the governance of Elizabeth, but that the rebellion is specifically Irish Catholic becomes evident from the repeated references to God in the text. Significantly, Mutabilitie comes from a bad seed and her rebellion against Jove recalls the rebellion of her ancestors:

Of that bad seed is this bold woman bred, That now with bold presumption doth aspire To thrust faire Phoebe from her siluer bed, And eke our selues from heauens high Empire, (7.6.21.1-4) 
Spenser may be alluding to events in Ireland: here Jove speaks of evil lineage and rebellion against the empire of the gods in much the same way as Irenius and the speaker in the "Supplication" spoke with the collective voice of English Protestant planters in Ireland against the Scythian Irish who rebel against Elizabeth or 'fair Phoebe'. Although Mutabilitie is said to rebel against all the gods, emphasis is placed on her rebellion against Jove and Cynthia and this is significant in terms of the war in Ireland: in the "Supplication" rebellion against Elizabeth and her English subjects is, in effect, a rebellion against God because he is sympathetic to the Protestant cause. So in the Mutabilitie Cantos rebellion against the moon goddess Cynthia (Elizabeth) is the beginning of a process that leads to rebellion against God himself (as a pro-Protestant deity). When Mercury descends to the circle of the moon, sent by Jove to command Mutabilitie to come before him, her reply is one of disdain:

Where-at the Titanesse did sternely lower, And stoutly answer'd, that in euill hower He from his loue such message to her brought, To bid her leaue faire Cynthias siluer bower; Sith shee his loue and him esteemed nought, No more then Cynthia's selfe; but all their kingdoms sought.

Like the Irish rebels, Mutabilitie is contemptuous of "Cynthia's self" (Elizabeth) and Jove (God). In the Mutabilitie Cantos the "sonnes of God" addressed by Jove recall the status given by the author of "The Supplication" to Protestant English men. Just as the authors of "The Supplication" and the View offered counsel on the dire situation in Ireland so advice is given to Jove in "the empire of the heauens", the major difference being however that the counsel given in heaven is requested whereas that provided by our two authors was neither solicited nor particularly welcome. It seems clear that Jove's request for advice from the lesser deities is poetic wish-fulfilment on the part of Spenser who, as a Protestant English man-and thus supposedly nearer to God-would like to consider that such advice is welcomed by Elizabeth as God's representative on earth.

The story of Molanna's betrayal of Diana is the second example of rebellion and disloyalty against a moon goddess in the Mutabilitie Cantos. The narrator claims that Ireland used to be a favourite holiday resort for the gods until the disloyalty of one of Diana's nymphs. As in the story of Mutabilitie's rebellion, a woman is the source of treachery and rebellion, recalling the status of Mutabilitie as a Titan and thus her association with Argante. When Ireland was blessed by the presence of Diana it prospered:

Whylome, when IRELAND florished in fame Of wealths and goodnesse, far aboue the rest Of all that beare the British Islands name, The Gods then vs'd (for pleasure and for rest) Oft to resort there-to, when seem'd them best: But none of all there-in more pleasure found, Then Cynthia; that is soueraine Queene profest Of woods and forrests, which therein abound, 
Fitzpatrick, Joan. 2000b. Irish Demons: English Writings on Ireland, the Irish and Gender By Spenser and His Contemporaries. Lanham. University Press of America.

Sprinkled with wholsom waters, more then most on ground.

(7.6.38.1-9)

Ireland was once wealthy and fertile but because of rebellion and Diana's reaction to that rebellion, it has become degenerate: "Arlo through Dianaes spights / (Beeing of old the best and fairest Hill / That was in all this holy-Islands hights) / Was made the most vnpleasant, and most ill" (7.6.37.5-9). That the story alludes specifically to Irish rebellion is suggested by the fact that the nymph who is made "corrupt" and betrays Diana is native to the land: as William Keach points out, 'Molanna' is Spenser's name for the Irish river Behanna (Keach 1990, 60). Yet if this story depicts rebellion against Elizabeth the narrator also stresses that Diana's departure from Arlo hill is desertion: she has "abandond" the brook, and "quite forsooke" the forests and country side:

Them all, and all that she so deare did way, Thence-forth she left; and parting from the place, There-on an heauy haplesse curse did lay, To weet, that Wolues, where she was wont to space, Should harbour'd be, and all those Woods deface, And Thieues should rob and spoile that Coast around. Since which, those Woods, and all that goodly Chase, Doth to this day with Wolues and Thieues abound: Which too-too true that lands in-dwellers since haue found. (7.6.55.1-9)

This may be a criticism by Spenser of what he perceives to be Elizabeth's political and military disengagement in matters relating to Ireland. In the View Eudoxus tells Irenius that Ireland's problems

proceede rather of the vnsoundnes of the Counsells and Plottes, which youe saie haue bynne often tymes laied for her reformacions or of faintnes in followinge and effectinge the same, then of anye suche fatall Course or appointment of god as youe misdeeme ... (Spenser 1949, 44)

Another story which involves Diana, featuring Faunus and an unfortunate nymph, is detailed in Book 2. Guyon, who has tried without success to clean the bloody hands of Ruddymane in a well, is told the story of the well by the Palmer. A virgin, one of Flora's nymphs, being chased by the lustful Dan Faunus asked Diana to allow her to die a maid whereby Diana transformed her into stone pouring out tears as water. Ruddymane's hands cannot be cleansed because the well will not allow its pure water to be stained (2.2.1-9). The purity of the water signifies the chastity of the nymph and Diana. The story in the Mutabilitie Cantos is an inversion of the former: in Book 2 the water in the well remains pure because of the intervention of Diana whilst in the Mutabilitie Cantos the water of Ireland and the land itself have been made impure because of Diana's abandonment. The water in which she used to bathe has become tainted and the landscape has also been made degenerate by her curse:

Thence-forth abandond her delicious brooke; In whose sweet streame, before that bad occasion, So much delight to bathe her limbes she tooke: 
Ne onely her, but also quite forsooke All those faire forrests about Arlo hid, And all that Mountaine, which doth over-looke The richest champian that may else be rid, And the faire Shure, in which are thousand Salmons bred. (7.6.54.2-9)

In "Mapping Mutability: or, Spenser's Irish Plot" Julia Reinhard Lupton coins the phrase 'Irish plot' to denote an Elizabethan genre which includes the View and was concerned with "English strategies for Irish reform, the cartographic projects of surveying and mapping which furthered them, and more generally, a geographical, antiquarian approach to Irish history" (Lupton 1993, 93). She points out that a key word in Spenser's Irish plot is 'waste' and that both the View and the Mutabilitie Cantos map Ireland as a wasteland to defend a policy of further wasting prior to its plantation with fresh inhabitants (Lupton 1993, 93-94). What Lupton fails to mention is that 'waste' is central not only to the View and the Mutabilitie Cantos but the entire poem. Allusions to Ireland as a wasteland pervade The Faerie Queene: it is an epithet used to describe the devastation wreaked upon the landscape by the dragon in Book 1 (1.1.5.8, 1.7.44.5, and 1.11.1.3); the landscape associated with Acrasia and the island of the lascivious Phaedria in Book 2 (2.1.22.2, 2.6.11.3); the landscape of Fairyland in Book 3 (3.1.3.1, 3.6.17.1, 3.10.40.3); and the pastoral landscape in Book 6 (6.11.26.7). This waste culminates in the last, incomplete, book of the Mutabilitie Cantos in which for the first time in the poem the narrator explicitly refers to the wasted land of Ireland. For Spenser, mutability, degeneration, and waste occur in Ireland not only as a direct result of Molanna's rebellion but because of Diana's actions. Hackett's claim that Spenser uses lunar imagery in the Mutabilitie Cantos to question rather than endorse the elevation of Elizabeth as a sacred icon, and that his negativity "is partly generated by dissent from Elizabeth's Irish policy" has a solid foundation (Hackett 1995, 191). Diana has not only abandoned Ireland but put a curse upon it. She has, by her absence, damned it to be a desolate wasteland and thus the Mutabilitie Cantos constitute not only a criticism of the rebellious Irish and degenerate Old English in Ireland but an extended criticism of Elizabeth's policy on Ireland.

\section{Notes}

1. The Pale was the region under English rule which in the early modern period consisted of Dublin, Kildare, Meath and Louth.

2. The term 'New English' describes the sixteenth- and seventeenth-century English settlers in Ireland. 'Old English' is used to describe the descendants of the twelfth-century Anglo-Norman settlers in Ireland and 'Native Irish', or 'Gaelic Irish', 
the indigenous inhabitants of the island. There is disagreement between Nicholas Canny and Ciaran Brady as to whether the descendants of the twelfth-century AngloNorman settlers should be called 'Old English' or 'Anglo-Irish' (Canny \& Brady 1988, $203 n 9,212 n 5)$. Canny is right to point out that the term 'Anglo-Irish' best defines those descended from the Elizabethan and Cromwellian conquests of Ireland.

3. The View was first attributed to Spenser by its first editor James Ware in 1633, thirty four years after the poet's death. Manuscripts circulating in the early 1600s have fuller versions of the View but it is not clear who is responsible for the complex pattern of redaction displayed across the early versions and perhaps some or all the material was written by someone other than Spenser. Andrew Hadfield and Willy Maley's recent edition of the View (Spenser 1997) uses Ware's text but the Variorum edition is based on a manuscript then thought to contain "the most nearly complete text" (Spenser 1949, 506). Bibliographical scholarship has progressed significantly in the last 50 years and a fresh look at the problem is needed. Jean Brink, who is working on a biography of Spenser, considers another text often attributed to him ( $A$ Brief Note of Ireland) to be certainly by someone else and has pointed to the weakness of the evidence linking the View to Spenser (Brink 1994; Brink 1997). Brink is partly answered in chapter 8 of Maley 1997. While the debate continues I confine myself to noting that if Spenser wrote the View and A Brief Note then the ideological, verbal, and thematic parallels that exist between these prose texts and The Faerie Queene can be explained by their being products of the same mind. If Spenser did not write the View and A Brief Note then the parallels can be explained by a shared New English Protestant mind-set.

4. Falkiner's transcription in full of Gernon's manuscript (Stowe ms. vol. 28, fol. 5) is the earliest printed edition of Gernon's Discourse.

5. Bernhard Klein, writing about early modern maps of Ireland, notes that in the Irish section in Laurence Nowell's General Description of England and Ireland (156465) "Britain visibly curves westward as if to bend over and encircle its neighbouring isle". This differs from the medieval tradition of the "Gough" map, evident in the first printed map of the British isles by George Lily (1548) where Britain is upright in shape and Ireland is "an oddly-shaped smaller island that does not really seem to belong there". Klein concurs with Michael Neill that coupled with the insistence that the Irish should be kept at a distance because of their savagery was the contradictory desire to incorporate Ireland within England's borders for English national security. The pictorial attempt at what Klein calls "geographical appropriation" is, however, undermined by the "Large clusters of green [which] suggest the intractability of a wild and barbaric landscape . . ." (Klein 1998, paragraph 13).

6. For Elizabeth as national and religious mother and nurse see Hackett 1995, 5052, 118-119, 164-165. See also 77-78 where Hackett lists contemporary examples.

7. See Klein 1986 especially chapters 6 and 8.

8. For evidence that E. K. is a Spenser persona see Spenser 1989, 6-9.

9. For example see Hadfield 1997, Maley 1997, and Baker 1997, 66-123. 
Fitzpatrick, Joan. 2000b. Irish Demons: English Writings on Ireland, the Irish and Gender By Spenser and His Contemporaries. Lanham. University Press of America.

10. See Spenser 1932, 422-95.

11. On Spenser's use of the Revelation see also Hankins 1972, 40-57.

12. Of the twenty eight editions of the complete Bible published in English from 1576 to 1586 twenty one were the Geneva Bible and only seven the Bishops' version (Shaheen 1976, 17-18).

13. Rosinger also states that a poem thought to be by John Boys, from a collection published at Cambridge in 1603, praises Elizabeth with reference to her motto by the ambiguous repetition of 'Una' so that it seems like a name (Rosinger 1968, 14). A link between the name 'Una' and Elizabeth 1 is made by $\mathrm{C}$. Bowie Millican who refers to "Carminum Sylua", a Latin poem written by Thomas Drant in praise of Elizabeth where he refers to her as "virtutibus vna, / Vna meam minuens musam". Millican supports his conclusion with reference to Richard Harvey who described Elizabeth as the "Vna of all the women in the earth" in Philadelphus, or A Defence of Brutes, and the Brutans History (Millican 1939, 252, 261).

14. All quotations of The Faerie Queene will be from Spenser 1909a and Spenser 1909b.

15. Camden's Britannia was first published in Latin in 1586. The 1695 English translation by Edmund Gibson is more reliable than the earlier 1610 translation by Philemon Holland (see the introduction to the 1695 text).

16. With reference to Irenius's account of what occurred at Smerwick in the View Pauline Henley claims that Irenius is "voicing Spenser's own sentiments" (Henley 1928, 29). Similarly Judson, in his biography of Edmund Spenser, refers to Irenius as Spenser's "mouthpiece" (Judson 1945, 92).

17. For an early study of the woman-as-land trope with particular reference to America see Kolodny 1975, 10-25. See also Patricia Parker's chapter on how this trope functions with regard to rhetoric, gender and property (Parker 1987, 126-54).

18. In the View Irenius describes the glib as "a thicke Curled bushe of haire hanginge downe over theire eyes and monstrouslye disguisinge them" (Spenser $1949,99)$ and the woollen cloak or mantle as "a fitt howsse for an outlawe a mete bedd for a Rebell and an Apte cloake for a thefe" (Spenser 1949, 100).

19. Shakespeare's plays will be quoted from early printed texts chosen to be closest to his words or more loosely to reflect Spenser's cultural milieu as appropriate. To aid the reader corresponding act, scene and line numbers from Shakespeare 1988 will also be provided.

20. Volume 4 of Moryson's Itinerary (1617) contains a brief summary of twenty-five unfinished chapters. Parts of the manuscript of these chapters, not printed in the Itinerary, were edited by Charles Hughes and published in Shakespeare's Europe (Moryson 1903). Falkiner's edition includes material not published by Hughes and so reproduced by Falkiner for the first time; this includes my quotation. 
21. This motif appears on an altar at Klosterneuberg, executed in 1181 by Nicholas of Verdun and the first extant literary reference to it occurred in Peter Comestor's commentary on Genesis, "where the Venerable Bede is credited with explaining the appearance of the Serpent with a woman's face as a reflection of the appeal of like to like in the Temptation of Eve" $(1978,103)$. J. M. Evans refers to Peter Comestor's Historia Scholastica as "the most influential and characteristic of the medieval Biblical commentaries" (Evans 1968, 168). Frye explains that apparently no known work by Bede contains the reference ascribed to him by Comestor (Frye 1978, 103).

22. Andrew Hadfield claims that Error is a dragon (Hadfield 1997, 133) but it seems clear that by making his monster a hybrid female-serpent Spenser intended his readers to think of the serpent in the garden of Eden.

23. The passage that Campion refers to is in Strabo's Geography $(1923,4.5 .4)$. This line is echoed in the View when Irenius refers to the Irish, corrupted by the Roman Catholic Church, as having "[drunk] of that Cupp of fornicacion with which the purple Harlott had then made all nacions drunken" (Spenser 1949, 137).

24. Waters cites from Bullinger 1561, Oo7r and Marlorat 1574, Kk5v.

25. For a synopsis of critical responses to the Bower of Bliss episode see Alpers 1990.

26. See Jenkins 1937, 345 and Derricke 1581, C2r.

27. Diane Purkiss claims that James 1 "argued for the reality of witches' compacts with the devil, and believed that he had himself been the target of witches' machinations". He was personally involved in a trial which took place in Scotland in 1591 and which "showed the influence of Continental theories of diabolic pacts and sexual transgression, unlike most English trials" (Purkiss 1996, 199). Furthermore, his Daemonologie is an endorsement of the notions of Continental pact witchcraft (Purkiss 1996, 207).

28. Purkiss points out that James 1 believed that his life had been threatened by the witches' attempts to raise a storm at sea. Although similar cases are present in English records interference with the weather was more usual on the Continent (Purkiss 1996, 227n26).

29. Ewen's work was published in the 1920s and 1930s but it still merits study. Keith Thomas indicates its value: "Ewen's work, which has been undeservedly neglected, was of very high scholarly quality and is the essential starting-point for any analysis of English witch-prosecution" (Thomas 1971, 435). Similarly Ewen is cited by Willis (1995) and Purkiss (1996), in their scholarly works on witchcraft. Montague Summers, who published around the same period, has also produced valuable research.

30. Purkiss claims that the elite belief in the diabolical pact and popular anxiety about the witch's perverse maternal effusions fused in the notion of the sucking demon (Purkiss 1996, 130-36). 
31. 'Usquebaugh' is literally 'water of life' ie whiskey (OED sb. 1.a.).

32. Diane Purkiss, who makes this observation, cites D4 of Stubb's book but the reference to the witch-like Catherine surrounded by familiars appears on B5r.

33. With reference to the "Rosiere" worn on her head Hamilton points out the flower's associations with Venus and Acrasia (2.12.77.1) but neglects to mention its association with the Virgin Mary (the Queen of Heaven) and Elizabeth (the Virgin Queen) which further reinforces Alma as a surrogate for Elizabeth. For associations between Elizabeth and the rose see Strong 1977, 56-83.

34. Critics largely concur that Artegall represents Lord Grey. Although Talus is not usually identiified with any particular person, Christopher Highley makes a convincing arguement that Talus might represent Richard Bingham, governor of Connaught, whose sobriquet was 'the Flail of Connaught' (Highley 1997, 116-20).

35. A similar process is at work in Spenser's depiction of Britomart. As Simon Shepherd points out, Britomart's power comes from her chastity which "produces order and restraint" throughout the poem (Shepherd 1989, 77).

36. See Phillips 1964.

37. See Leslie 1571 and Blackwood 1587. Leslie published under the pseudonym of Morgan Philippes, the place of publication was really Louvain and the publisher John Fowler (Allison \& Rogers 1956). The circumstances under which Leslie's Defence was published are outlined in Phillips 1964, 87-89. Blackwood's work was published anonymously and the place of publication was really Paris (Allison \& Rogers 1956).

38. About fifty poems of this sort, damning Elizabeth as a murdering jezebel and praising Mary as a martyr, were published in a series of related collections that appeared throughout 1587 and 1588 all over Europe. Although the poems were written in different languages and by different authors, Blackwood was one of the principal contributors (Phillips 1964, 162).

39. All is True, first printed in the First Folio, is the title by which King Henry 8 was known by its first audiences. It is thought that Fletcher collaborated with Shakespeare on the play (Wells et al. 1987, 618).

40. For convenience the play is "Shakespeare's" but there were 4 writers:

Shakespeare, Thomas Nashe, and two others who, although unknown, "have strong similarities to the dramatic writings of Robert Greene and George Peele" (Wells et al. 1987, 217).

\section{See Heliodorus [1569?].}

42. In Book 3 of the poem, three stanzas are devoted to the description of Britomart's beauty (3.9.20-23) which includes the traditional ideal of long blonde hair: "golden locks" that "raught vnto her heeles; like sunny beames" (3.9.20.4-6). 
43. As Hackett points out, this view was first put forward by E.C. Wilson, Frances Yates and Roy Strong and influenced later critics such as Stephen Greenblatt and Lisa Jardine (Hackett 1995, 6-10).

44. The text is: "And Kings shalbe thy nourcing fathers, and Quenes shalbe thy nources", which is glossed in the Geneva Bible as "Meaning, that Kings shalbe conuerted to the Gospel and bestow their power, \& autoritie for the preseruation of the Church". (Hackett 1995, 4).

45. Church noted this when he said "Perhaps it may be unnecessary to observe that this free Censure of the Fair Sex comes from the mouth of a professed Debauchè [sic]" (Spenser 1758, 165).

46. See Hackett 1995, 29-34.

47. One of the signs that indicates the true nature of the False Florimell is its rolling eyes: the sprite has the ability "To stirre and roll them, like a woman's eyes"

(3.8.7.4). Throughout The Faerie Queene a woman's wandering eyes indicate a lascivious nature. This is true of Malecasta: "Her wanton eyes, ill signes of womanhed, / Did roll too lightly, and too often glaunce, / Without regard of grace, or comely amenenaunce" (3.1.41.7-9). Similarly Hellenore returns the flirtatious glances of Paridell "But in his eye his meaning wisely red, / And with the like him answerd euermore" (3.9.28.6-7).

48. For Elizabeth 1 as the handmaid of God see Hackett 1995, 58- 61.

49. For other examples of Elizabeth as a Christ-like figure see Hackett 1995, 8081, 109, 113, 142-3, 221.

50. The colonized land as gendered sexual possession has been discussed in chapter 2 and will be considered again in chapter 7 .

51. 'Pussel' is a variant of 'pucelle'. The OED records both meanings: sb. 1. 'A girl, a maid' and $s b$. 2. 'A drab, a slut, a courtesan'. The former meaning is still current in the French.

52. The multiple representations of Elizabeth in The Faerie Queene are somewhat ambivalent, for example the positive figures of Belphoebe and Britomart are juxtaposed with the negative figure of the Amazon Radigund. For attitudes to the Amazon in the early modern period see Shepherd 1981, 13-16. For contemporary associations between Elizabeth and the figure of the Amazon see Schleiner 1978. On Elizabeth as Deborah see Hackett 1995, 39-40, 48-50.

53. The cult of Elizabeth as Astraea is explored in Yates 1947.

54. For example see the report of giant cannibals in John Mandeville's Travels $(1963,107 / 25)$. A literary example of a traveller's report is evident in Shakespeare's Othello where Othello recalls having told Desdemona and her father stories of "the Canibals that each others eate, / The Antropophague, and men whose heads / Grew beneath their shoulders" (Shakespeare 1623, ss5v; 1.3.142-144). 
55. The description of these savages recalls Error and her brood (1.1.14-15) whose Irish Catholic dimensions are explored in chapter 2.

56. For a solid introduction to classical, epic, and Romance analogues relating to woodland in Spenser's allegory see Hankins 1971, 60-73.

57. Bernhard Klein claims that the inability to fully delineate Ireland in maps of the period corresponds to the way in which Ireland was represented on the Elizabethan stage where "Ireland is rarely more than a shadowy and indistinct background of the dramatic scenery, always only partially coming into view" (Klein 1998, paragraph 5). Klein considers the way in which a number of plays from the Shakespeare canonThe Comedy of Errors, 2 Henry 6, Richard 2, and Henry 5-"invest to different degrees in the image of a nebulous territory beyond the porous borders of the national sphere, at once confirming, and posing a threat to, England's cultural integrity" (Klein 1998, paragraph 6).

58. See Jewel 1565, 4v and Hooker 1888, 554. Waters also quotes from Fulke but cites pages which appear to have no relevance to the discussion.

59. Similarly in the episodes featuring Flourdelis, Serena, and Pastorella the rabble are referred to by the narrator as flies (5.11.58.2, 6.8.40.2, 6.11.48.1-9).

60. See Blenerhasset 1610, A3v.

61 . The Lee valley was a densely wooded area in the early modern period (McCracken 1959, 282).

62. Hiram Morgan, who presents this previously unpublished text, claims that the "Questions and Answars" was written in the first half of 1597 probably by Captain Nicholas Dawtrey, "an Ireland hand and expert on national defence" (Morgan 1995, 81-82).

63. Although Williams is correct in his assertion that the word 'saluage' is used to describe a wood dweller who "partakes somewhat of the nature of the woods" he is wrong to claim that the word "has no connotation of ferocity or cruelty" (Williams 1967, 49). Throughout The Faerie Queene woodland is an unpredictable and hostile environment (like the Irish interior) and most of its inhabitants are aggressive, although there are exceptions: the Saluage Man in Book 6 and the Saluage Nation in Book 1.

64. Like Serena, who is attacked by the Saluage Nation in Book 6, Amoret has ventured into her enemy's territory making the whole episode somewhat problematic because it may indicate a degree of complicity on her part.

65. In the 14th and 15th centuries the Wild Man "became gradually transformed from an object of loathing and fear . . . into an object of open envy and even admiration" (White 1972, 22).

66. In his study of O'Neill and the Nine Years war Hiram Morgan points out that there is no evidence for the popular assumption that O'Neill was raised in the 
Sidney household in England (Morgan 1993, 92). O'Neill himself referred to his education amongst the English rather than in England itself. Morgan claims that "Hugh O'Neill was a ward of Giles Hovenden, an English settler in Laois" (Morgan 1993, 93).

67. The fact that one of the women is old only shows the degeneracy of Lust because for Spenser advanced age carries a negative signification. The old woman disgusts Belphoebe even though she heroically sacrifices her own body in order to preserve the chastity of Aemylia. We are told nothing of her history, only that she is old and therefore ugly. This is indicative of Spenser's attitude to old women throughout The Faerie Queene, as displayed in the characters Occasion (2.4.4-5), Impotence and Impatience (2.11.23), Slander (4.8.23-26), Ate (4.1.19-30), and Envy and Detraction (5.12.28-36).

68. Amongst the foremost discussions of Book 5 in relation to Ireland are Spenser 1898, Greenlaw 1912, Spenser 1918, Henley 1928, Hough 1962, McCabe 1989a, McCabe 1993, and Carroll 1990.

69. See Camden 1971, 963. Hamilton mistakenly claims that Irena is an anagram of lerne but the final 'e' (rather than an 'a') may simply be a typographical error (Spenser 1977, 530).

70. Munera has been virtually ignored by critics. When she is mentioned there is a tendency to inaccuracy. She is referred to only in passing by Andrew Hadfield who, apparently confusing her with Irena, mis-spells her name 'Murena' (Hadfield 1997, $148,157,225)$ and in an entry on Book 5 in The Spenser Encyclopedia she is wrongly identified by Michael O'Connell as "Pollente's wife" (O'Connell 1990, 281).

71. C. W. Lemmi thought the episode featuring Munera and Pollente "symbolical of the corrupting power of money" (Lemmi 1929, 282). T. K. Dunseath also saw the episode in general terms, claiming that the destruction of Munera, the gold, and the castle is of "universal significance", and a fitting example for all who would attempt to corrupt judges with gifts (Dunseath 1968, 94). Merlin L. Neff read the episode as a general attack on the abuse of monopolies, specifically "extortionate tolls" which existed in both England and Ireland in the early modern period. For Neff, the element of bribery is "merely incidental", which implies that he thinks the depiction of Munera is also incidental (Neff 1934, 159). Although Dunseath rightly acknowledges that Munera is integral to Spenser's consideration of financial corruption in this episode, his assertion that the episode is "universal" does not take into account the political and religious ideology of the poem.

72. Gough thought that the episode featuring Munera and Pollente alluded to ambush and seduction as tactics of guerilla warfare in Ireland. He recounts an incident in which one of the Irish rebels, "a fair young harlot" sent by Desmond to seduce the constable of a garrison in Limerick, suffered a fate similar to that of Munera by being thrown into a river with a stone around her neck (Spenser 1918, 176). The allegory has been interpreted more broadly by Pauline Henley as having strong allusions to Catholic Spain and Catholic Ireland: "Pollente begins as the power of Spain, and ends as Sir John of Desmond; his daughter the Lady Munera begins as the wealth of Spain, and as some of the Spanish treasure was used to 
Fitzpatrick, Joan. 2000b. Irish Demons: English Writings on Ireland, the Irish and Gender By Spenser and His Contemporaries. Lanham. University Press of America.

finance the expedition to Smerwick, she seems to end up as that unlucky garrison, and is slain" (Henley 1928, 140). Andrew Hadfield suggests that Spenser may have been thinking specifically of Irish Catholicism because the fate of Pollente resembles that of the rebel Rory Oge O'More as described in John Derricke's The Image of Ireland (1581) (Hadfield 1997, 159).

73. The identification of Munera with Lady Meed was also made by Hough (1962, 194), Hamilton (1977, 526), and Heale (1990).

74. Of course Talus has a classical precedent in Talos, the brazen man of ancient Crete (Apollodorus 1921, 1.9.26).

75. The crucial word here is 'reformation'. As McCabe points out, in the View Spenser uses the word 'reform' in a political/religious sense so that it carries with it "the electrifying associations of 'reformation"' (McCabe 1989b, 113).

76. Pollente's headless body is carried down "the Lee" (5.2.19.1-2) which is almost certainly a reference to the Irish river near Cork.

77. On the formation of the Catholic League by Henry, the duc de Guise, see Briggs 1977, 25.

78. On the legend of Antigoon and Brabo see also Wegg 1916, 1.

79. This is an allusion to the parable of the ship of state articulated in Plato 1908 , 2.4.488-490.

80. Willy Maley has recently drawn attention to the less obvious coupling of Spenser and Scotland, which he claims has been overlooked in the attention given to Spenser's relationship with Ireland and the Irish (Maley 1996).

81. Critics concur that Spenser's Saluage Nation is a typical contemporary representation of the Irish. That the Brigants also represent Irish rebels was recognised by Tonkin, who states that Serena is rescued "from a society whose behaviour closely parallels that of the Brigands" (Tonkin 1972, 144).

82. Oram outlines Spenser's debts to Greek romance but acknowledges that "The motif of brigands living at the edge of civilized society . . may owe something to Spenser's concern with the bands of Irish outlaw rebels mentioned in [the] Vewe . ..." (Oram 1990, 112). Raids regularly took place between rival Irish lords and upon the English Pale (Quinn \& Nicholls 1976, 33).

83. The Short Title Catalogue indicates that the woodcut illustrations designed to accompany Derricke's text can be found in only two copies of The Image of Ireland, one held by the National Library of Scotland in Edinburgh, and the other by Edinburgh University library (Pollard \& Redgrave 1986, 302). Although the collection of woodcuts attached to the Edinburgh University Library copy is incomplete, it has the illustration of a cattle raid reproduced in Moody et al. 1976, plate 2.

84. As we saw in chapter 2, the same is true of Una. 
85. Gottfried makes this claim in the variorum edition of the View: "[Irenius] must be associated with Irena, the name for Ireland in F.Q. 5.1, since Irenius is an Englishman who has spent some time in Ireland" (Spenser 1949, 278).

86. Critical analysis of Spenser's use of the blazon in Book 6 is usually restricted to the episode featuring Serena and the cannibals. For examples, see McNeir 1969, 128, Fogarty 1989, 100-01, and Rowe 1989, 322-26.

87. Heffner, Bennett, Jones, Phillips, Hamilton, and Prescott all recognize this episode as a thinly veiled historical allegory of Elizabeth's aid to Henri of Navarre, the first Bourbon King of France (Spenser 1936, 324-35; Bennett 1942, 191; Jones 1930, 268; Phillips 1970, 117; Spenser 1977, 609; Prescott 1990, 121). Henri's succession to the throne had been challenged by the Catholic League supported by Philip of Spain. Formerly a Huguenot (French Calvinist), Henri renounced his Protestant faith and converted to Catholicism in order to rule France (see Spenser 1918, 303-05 and Greengrass 1995). Although an Irish Catholic connection is made by Heffner, who claims that the "rude rout" that torments Flourdelis "is unmistakably such as Spenser saw in Ireland", he does not elaborate upon this suggestion (Spenser 1936, 260).

88. The description of her sumptuous clothing-she is dressed in "roiall robes" with "many lewels dight" (5.11.60.7) - is reminiscent of the clothing of Duessa and thus the Whore of Babylon. Duessa is given "gold and purple pall to weare" with a "triple crowne" and is "endowd with royall maiestye" by Orgoglio (1.7.16.3-5).

89. Flourdelis's trauma may be compared with Serena's state of numb shock (6.8.50-51), which was crudely characterized as unloving ingratitude by Hamilton (Spenser 1977, 680).

90. Flourdelis's shame implies that her transgression has been a sexual one, but her confusion also implies the shock consistent with a victim of sexual assault who is then subjected to a further verbal assault by Artegall.

91. The blazon enacts a metaphorical dissection of a female figure but, as A. Leigh DeNeef notes, the cannibals take to a literal extreme the violent desires latent in the poetic mode because they want to literally dissect and consume Serena (DeNeef 1990, 637). For a detailed discussion of the ambivalences latent in the poetic blazon see Vickers 1981 and Vickers 1985, and for its relevance to Munera's death see chapter 6 .

92. 'Mankind' is the correct gender specific term: degeneration and rebellion are enacted by a rebellious female against men.

93. Richard J. Berleth points out that in a letter to Spenser dated 1580 Gabriel Harvey ridicules Spenser's complaints about the world's inconstancy (Berleth 1995, 42-43). The letter is published in Harvey 1966, 140-50.

94. The assertion that even the wisest can be fooled may be a reference to Elizabeth's misplaced trust in O'Neill. 
95. Hamilton points out, "As Holiness is the bedrock on which the virtues are founded, Temperance is the basis of the virtues themselves" (Spenser 1977, 163).

96. This was the 'Surrender and regrant' policy, described as follows by Nicholas Canny:

The essence of the scheme was that the ruling chieftains should surrender the lands of their lordships to the king and receive them back as a fief from the crown, the fief to pass on to the eldest son under the law of primogeniture. It was, in other words, intended to substitute the English for the Gaelic method of land tenure in the hope that the chieftains, recognizing that they held their lands from the king, would pay him due obedience, or at least desist from causing disturbances. The policy was pursued vigorously during the 1540s when Sir Anthony St Leger served as lordlieutenant. (Canny 1976, 33)

97. See 'An Act for the English Order, Habit, and Language' in Maxwell 1923, $112-$ 14.

98. Only the eleventh and (unfinished) twelfth books of the poem exist (Raleigh 1965, 25).

\section{Bibliography}

Aesop. 1964. Fables of Aesop. Trans. S. A. Handford. Harmondsworth. Penguin.

Allison, A. F. and D. M. Rogers. 1956. A Catalogue of Catholic Books in English Printed Abroad or Secretly in England: 1558-1640. Bognor Regis, UK. Arundel Press.

Alpers, Paul J. 1990. "Bower of Bliss." The Spenser Encyclopedia. Edited by A. C. Hamilton. Toronto. University of Toronto Press. 104-07.

Anderson, Judith H. 1970. "'Nor Man It Is': The Knight of Justice in Book V of Spenser's Faerie Queene." Publications of the Modern Language Association of America. 85.1. 65-77.

Anon. 1560. The Bible and Holy Scriptures Conteyned in the Olde and Newe Testament. Translated According to the Ebrue and Greke. With Moste Profitable Annotations. [Geneva Version]. Geneva. R. Hall.

Anon. 1995. "The Supplication of the Blood of the English Most Lamentably Murdered in Ireland, Cryeng Out of the Yearth for Revenge (1598)." Ed. Willy Maley. Analecta Hibernica. 36. 1-77. 
Apollodorus. 1921. The Library. Trans. James George Frazer. Vol. 1. 2 vols. The Loeb Classical Library. London. William Heinemann.

Arens, W. 1979. The Man-Eating Myth: Anthropology and Anthropophagy. New York. Oxford University Press.

Arens, W. 1986. The Original Sin: Incest and Its Meaning. New York. Oxford University Press.

Baker, David J. 1992. “"Wildehirissheman”: Colonialist Representation in Shakespeare's Henry V." English Literary Renaissance. 22.1. 37-61.

Baker, David J. 1993. "Off the Map: Charting Uncertainty in Renaissance Ireland." Representing Ireland: Literature and the Origins of Conflict, 1534-1660. Edited by Brendan Bradshaw, Andrew Hadfield and Willy Maley. Cambridge. Cambridge University Press. 76-92.

Baker, David J. 1997. Between Nations: Shakespeare, Spenser, Marvell, and the Question of Britain. Stanford. Stanford University Press.

Barber, Malcolm. 1997. "How the West Saw Medieval Islam." History Today. 47.5. 44-50.

Bennett, Josephine Waters. 1942. The Evolution of The Faerie Queene. New York. Burt Franklin.

Berleth, Richard J. 1995. "Fraile Woman, Foolish Gerle: Misogyny in Spenser's Mutabilitie Cantos." Modern Philology. 93.1. 37-53.

Blackwood, Adam. 1587. Martyre de La Royne D'Escosse. [Anon]. Edimbourg [really Paris]. J. Nafeild.

Blenerhasset, Thomas. 1610. A Direction for the Plantation in Ulster. London. E. Allde for J. Budge.

Borris, Kenneth. 1990. "Courtesy." The Spenser Encyclopedia. Edited by A. C. Hamilton. Toronto. University of Toronto. 194-95.

Briggs, Robin. 1977. Early Modern France 1560-1715. Oxford. Oxford University Press.

Brink, Jean R. 1994. "Constructing the View of the Present State of Ireland." Spenser Studies. 11. 203-28.

Brink, Jean. 1997. "Appropriating the Author of The Faerie Queene: The Attribution of the View of the Present State of Ireland and A Brief Note of Ireland to Edmund Spenser." Soundings of Things Done: Essays in Early Modern Literature in Honor of S. K. Heninger Jr. Edited by Peter E. Medine and Joseph A. Wittreich. London. Associated University Presses. 93-136. 
Bullinger, Heinrich. 1561. A Hundred Sermons Vpon the Apocalips. Trans. J. Daus. London. J. Day.

Bullough, Geoffrey, ed. 1973. Narrative and Dramatic Sources of Shakespeare. Vol. 7. 8 vols. London. Routledge and Kegan Paul.

Butlin, R. A. 1976. "Land and People, c. 1600." A New History of Ireland. 3. Edited by T. W. Moody, F. X. Martin and F. J. Byrne. Oxford. Oxford University Press. 14267.

Bynum, Caroline Walker. 1992. Fragmentation and Redemption: Essays on Gender and the Human Body in Medieval Religion. New York. Zone Books.

Camden, William. 1971. Camden's Brittannia, 1695: A Facsimile of the 1695 Edition Published By Edmund Gibson; (Translated From the Latin) (with an Introduction By Stuart Piggott and a Bibliographical Note By Gwyn Walters). Newton Abbot. David and Charles.

Campion, Edmunde. 1963. Two Bokes of the Histories of Ireland. Ed. A.F. Vossen. Assen. Van Gorcum.

Canny, Nicholas P. 1976. The Elizabethan Conquest of Ireland: A Pattern Established 1565-76. Hassocks, UK. Harvester.

Canny, Nicholas and Ciaran Brady. 1988. "Debate: Spenser's Irish Crisis: Humanism and Experience in the 1590s." Past and Present.120. 201-15.

Canny, Nicholas. 1983. "Edmund Spenser and the Development of an Anglo-Irish Identity." The Yearbook of English Studies. 13. 1-19.

Carroll, Clare. 1990. "The Construction of Gender and the Cultural and Political Other in The Faerie Queene 5 and A View of the Present State of Ireland: the Critics, the Context, and the Case of Radigund." Criticism. 32.2. 163-92.

Cavanagh, Sheila T. 1994. Wanton Eyes and Chaste Desires: Female Sexuality in The Faerie Queene. Bloomington and Indianapolis. Indiana University Press.

Chang, H. C. 1955. Allegory and Courtesy in Spenser: A Chinese View. Edinburgh. Edinburgh University Press.

Cheney, Donald. 1966. Spenser's Image of Nature: Wild Man and Shepherd in "The Faerie Queene". New Haven and London. Yale University Press.

Church, R. W. 1887. Spenser. English Men of Letters. London. Macmillan.

Daly, Peter M., Virginia W. Callahan and Simon Cuttler, eds. 1985. Andreas Alciatus. Vol. 1: The Latin Emblems. Indexes and Lists. 2 vols. Index Emblematicus. Toronto. University of Toronto Press. 
Davies, Sir John. 1612. A Discoverie of the True Causes Why Ireland Was Never Entirely Subdued, Untill His Majesties Raigne. London. W. Jaggard for J. Jaggard.

DeNeef, A. Leigh. 1990. "Serena." The Spenser Encyclopedia. Edited by A. C. Hamlton. Toronto. University of Toronto Press. 733.

Derricke, John. 1581. The Image of Irelande, with a Discouerie of Woodkarne, . . . Their Apptnesse, Celeritie, and Pronesse to Rebellion, [Etc.] Made By J. Derricke, 1578. and Now Published By the Saied Authour This Yere 1581. [In Verse]. London. [J. Kingston for] J. Daie.

Donne, John. 1669. Poems. London. T. N. for Henry Herringman.

Draper, John W. 1932. "Classical Coinage in The Faerie Queene." Publications of the Modern Language Association of America. 47.1. 97-108.

Dunseath, T. K. 1968. Spenser's Allegory of Justice in Book Five of The Faerie Queene. Princeton, NJ. Princeton University Press.

Evans, J. M. 1968. Paradise Lost and the Genesis Tradition. Oxford. Clarendon Press.

Ewen, C. L'Estrange. 1933. Witchcraft and Demonianism: A Concise Account Derived from Sworn Depositions and Confessions Obtained in the Courts of England and Wales. London. Heath Cranton.

Falkiner, C. Litton. 1904. Illustrations of Irish History and Topography, Mainly of the Seventeenth Century. London. Longman.

Fogarty, Anne. 1989. "The Colonization of Language: Narrative Structures in A View of the Present State of Ireland and The Faerie Queene, Book VI." Spenser and Ireland: An Interdisciplinary Perspective. Edited by Patricia Coughlan. Cork. Cork University Press. 75-108.

Frye, Roland Mushat. 1978. Milton's Imagery and the Visual Arts: Iconographic Tradition in the Epic Poems. Princeton. Princeton University Press.

Gainsford, Thomas. 1618. The Glory of England, or a True Description of Blessings, Whereby She Triumpheth Over All Nations. London. E. Griffin for T. Norton.

Gray, M. M. 1930. "The Influence of Spenser's Irish Experiences on The Faerie Queene." Review of English Studies. 6.21-24. 413-28.

Greenblatt, Stephen. 1980. Renaissance Self-Fashioning: From More to Shakespeare. Chicago and London. University of Chicago Press.

Greengrass, Mark. 1995. France in the Age of Henri IV: the Struggle for Stability. London. Longman. 
Fitzpatrick, Joan. 2000b. Irish Demons: English Writings on Ireland, the Irish and Gender By Spenser and His Contemporaries. Lanham. University Press of America.

Greenlaw, Edwin A. 1912. "Spenser and British Imperialism." Modern Philology. 9.3. 347-70.

Guazzo, Francesco Maria. 1970. Compendium Maleficarum: Collected in 3 Books From Many Sources, Showing the Iniquitous and Execrable Operations of Witches Against the Human Race, and the Divine Remedies By Which They May Be Frustrated. Ed. Montague Summers. Trans. E. A. Ashwin. London. Frederick Muller.

Hackett, Helen. 1995. Virgin Mother, Maiden Queen: Elizabeth I and the Cult of the Virgin Mary. Basingstoke. Macmillan.

Hadfield, Andrew and John McVeagh, eds. 1994. Strangers to That Land: British Perceptions of Ireland From the Reformation to the Famine. Ulster Editions and Monographs. 5. Gerrards Cross, UK. Colin Smythe.

Hadfield, Andrew. 1997. Edmund Spenser's Irish Experience: Wilde Fruit and Salvage Soyl. Oxford. Clarendon.

Hadfield, Andrew. 1999. "Spenser's Description of the Execution of Murrogh O'Brien: An Anti-Catholic Polemic?" Notes and Queries. 244. 195-96.

Hankins, John E. 1972. "Spenser and the Revelation of St. John." Essential Articles for the Study of Edmund Spenser. Edited by A. C. Hamilton. Hamden, CT. Archon. 40-57.

Hankins, John Erskine. 1971. Source and Meaning in Spenser's Allegory: A Study of The Faerie Queene. Oxford. Clarendon Press.

Harvey, Gabriel. 1966. The Works. Ed. Alexander B. Grosart. Vol. 1. 3 vols. New York. AMS Press.

Hawkins, Harriett. 1976. Poetic Freedom and Poetic Truth: Chaucer, Shakespeare, Marlowe, Milton. Oxford. Clarendon Press.

Heale, Elizabeth. 1990. "Munera, Pollente." The Spenser Encyclopedia. Edited by A. C. Hamilton. Toronto. University of Toronto Press. 481.

Heaney, Seamus. 1975. North. London. Faber and Faber.

Heliodorus. [1569?]. An Aethiopian Historie Written in Greeke . . . Englished By T. Underdoune. London. H. Wykes for F. Coldocke.

Hellwis, Edward. 1589. A Maruell, Deciphered. [An Exposition of Rev. Xii]. London. R. Robinson for J. Winnington.

Henley, Pauline. 1928. Spenser in Ireland. Dublin. Cork University Press. 
Highley, Christopher. 1997. Shakespeare, Spenser, and the Crisis in Ireland. Cambridge Studies in Renaissance Literature and Culture. 23. Cambridge. Cambridge University Press.

Hinton, Edward M. 1940. "Rych's Anothomy of Ireland, with an Account of the Author." Publications of the Modern Language Association of America. 55. 73101.

Holinshed, Raphael. 1587. The First and Second Volumes of Chronicles. (The Third Volume.) Newlie Augmented and Continued By J. Hooker Alis... Vowell Gent. and Others. (A. Fleming; F. Thin [I.e. Thynne; and J. Stow.]). 3 vols. London. [H. Denham,] at the expenses of J. Harison, G. Bishop, R. Newberie, H. Denham, and T. Woodcocke.

Holinshed, Raphael. [1577]. [ Vol I:] 1577. The Firste Volume of the Chronicles of England, Scotland, and Irelande. [Ireland 1509-47 By] (R. Stanyhurst.) 3 Pts. [Vol. II:] (The Laste Volume of the Chronicles). London. [H. Bynneman] for J. Harrison or Harison.

Homer. 1919. The Odyssey. Trans. A. T. Murray. Vol. 1. 2 vols. The Loeb Classical Library. London. William Heinemann.

Hooker, Richard. 1888. The Works. Arranged by John Keble. Vol. 2. 3 vols. Oxford. Clarendon Press.

Hough, Graham. 1962. A Preface to The Faerie Queene. London. Gerald Duckworth.

Hughes, Art J. 1988. "The Seventeenth-century Ulster/Scottish Contention of the Red Hand: Background and Significance." Gaelic and Scots in Harmony: Proceedings of the Second International Conference on the Languages of Scotland. Edited by Derick S. Thomson. Glasgow. University of Glasgow. 78-94.

Jenkins, Raymond. 1937. "Spenser with Lord Grey in Ireland." Publications of the Modern Language Association of America. 52.2. 338-53.

Jewel, John. 1565. A Replie Vnto M. Hardinges Answeare. London. H. Wykes.

Jones, Ann Rosalind and Peter Stallybrass. 1992. "Dismantling Irena: The Sexualizing of Ireland in Early Modern England." Nationalisms and Sexualities. Edited by Andrew Parker, Mary Russo, Doris Sommer and Patricia Yaeger. New York. Routledge. 157-71.

Jones, H. S. V. 1930. A Spenser Handbook. New York. Appleton-Century-Crofts.

Jonson, Ben. 1967. The Alchemist. Ed. F. H. Mares. The Revels Plays. London. Methuen.

Judson, Alexander C. 1945. The Life of Edmund Spenser. The Works of Edmund Spenser: A Variorum Edition. 11. Baltimore. Johns Hopkins. 
Keach, William. 1990. "Arlo Hill." The Spenser Encylopedia. Edited by A. C. Hamilton. Toronto. University of Toronto Press. 60.

Kermode, Frank. 1971. Shakespeare, Spenser, Donne. London. Routledge and Kegan Paul.

Klein, Bernhard. 1998. "Partial Views: Shakespeare and the Map of Ireland.", Internet, Online journal, http://purl.oclc.org/emls/04-2/kleinpart.htm. Early Modern Literary Studies. 4.2. 5.1-20.

Klein, Melanie. 1986. The Selected Works of Melanie Klein. Ed. Juliet Mitchell. London. Penguin.

Kolodny, Annette. 1975. The Lay of the Land: Metaphor as Experience and History in American Life and Letters. Chapel Hill. University of North Carolina Press.

Lemmi, C. W. 1929. "The Symbolism of the Classical Episodes in The Faerie Queene." Philological Quarterly. 8. 270-87.

Leslie, John. 1571. A Treatise Concerning the Defence of the Honour of Marie of Scotland. (A Treatise Touching the Right.-A Treatise That the Regiment of Women is Conformable.) [M. Philippes, pseud.] 3 Pts. Leodii [Louvain]. G. Morberium [J. Fowler].

Lewis, C. S. 1936. The Allegory of Love: A Study in Medieval Tradition. London. Oxford University Press.

Lupton, Julia Reinhard. 1993. "Mapping Mutability: or, Spenser's Irish Plot." Representing Ireland: Literature and the Origins of Conflict, 1534-1660. Edited by Brendan Bradshaw, Andrew Hadfield and Willy Maley. Cambridge. Cambridge University Press. 93-115.

MacCaffrey, Wallace. 1993. Elizabeth I. London. Edward Arnold.

MacFarlane, Alan. 1970. Witchcraft in Tudor and Stuart England: A Regional and Comparative Study. London. Routledge \& Kegan Paul.

Maley, Willy. 1996. "Spenser and Scotland: The View and the Limits of Anglo-Irish Identity." Prose Studies. 19.1. 1-18.

Maley, Willy. 1997. Salvaging Spenser. Basingstoke. Macmillan.

Mandeville, John. 1963. The Bodley Version of Mandeville's Travels. Ed. M. C. Seymour. The Early English Text Society. 253. London. Oxford University Press.

Marlorat, Augustine. 1574. A Catholike Exposition Vpon the Reuelation of Sainct John. [Tr.] A. Golding.. London. H. Binneman for L. Harison and G. Bishop.

Maxwell, Constantia. 1923. Irish History From Contemporary Sources (1509-1610). London. Allen and Unwin. 
McCabe, Richard A. 1987. "The Masks of Duessa: Spenser, Mary Queen of Scots, and James VI." English Literary Renaissance. 17. 224-42.

McCabe, Richard A. 1989a. "The Fate of Irena: Spenser and Political Violence." Spenser and Ireland: An Interdisciplinary Perspective. Edited by Patricia Coughlan. Cork. Cork University Press. 109-25.

McCabe, Richard A. 1989b. The Pillars of Eternity: Time and Providence in The Faerie Queene. Dublin Studies in Medieval and Renaissance Literature. Blackrock, County Dublin. Irish Academic Press.

McCabe, Richard A. 1993. "Edmund Spenser, Poet of Exile." Proceedings of the British Academy. 80. 73-103.

McCracken, Eileen. 1959. "The Woodlands of Ireland Circa 1600." Irish Historical Studies. 11.44. 271-96.

McNeir, Waldo F. 1969. "The Sacrifice of Serena: The Faerie Queene VI.viii.31-51." Festschrift für Edgar Mertner. Edited by Bernhard Fabian and Ulrich Suerbaum. Munich. Wilhelm Fink. 117-56.

Millican, C. Bowie. 1939. "Spenser's and Drant's Poetic Names for Elizabeth: Tanaquil, Gloriana, and Una." Huntington Library Quarterly. 2. 251-63.

Milward, Peter. 1977. Religious Controversies of the Elizabethan Age: A Survey of Printed Sources. London. The Scholar Press.

Montrose, Louis Adrian. 1983. "Of Gentlemen and Shepherds: The Politics of Elizabethan Pastoral Form." English Literary History. 50.3. 415-59.

Montrose, Louis. 1993. "The Work of Gender in the Discourse of Discovery." New World Encounters. Edited by Stephen Greenblatt. Berkeley. University of California Press. 177-217.

Moody, T. W., F. X. Martin and F. J. Byrne, eds. 1976. A New History of Ireland. Vol. 3. 9 vols. Oxford. Oxford University Press.

Morgan, Hiram. 1993. Tyrone's Rebellion: The Outbreak of the Nine Years War in Tudor Ireland. Royal Historical Society Studies in history. 67. Woodbridge. Boydell.

Morgan, Hiram. 1995. "A Booke of Questions and Answars Concerning the Warrs or Rebellions of the Kingdome of Irelande." Analecta Hibernica. 36. 79-132.

Moryson, Fynes. 1617. An Itinerary Written By Fynes Moryson Gent. (Containing His Ten Yeeres Travell Through the Twelve Dominions of Germany, Bohmerland, . . . France, England, Scotland, and Ireland). London. J. Beale. 
Moryson, Fynes. 1903. Shakespeare's Europe: Unpublished Chapters of Fynes Moryson's Itinerary, Being a Survey of the Condition of Europe at the End of the 16th Century. Ed. Charles Hughes. London. Sherratt \& Hughes.

Neff, Merlin L. 1934. "Spenser's Allegory of the Toll Bridge." Philological Quarterly. 13. 159-67.

Nelson, William. 1963. The Poetry of Edmund Spenser: A Study. New York. Columbia University Press.

Niccols, Richard. 1610. "England's Eliza." A Mirour for Magistrates. Newly Enlarged with a Last Part. Edited by John Higgins and R. Niccols. London. F. Kyngston. Eee2r-LIl6r.

O'Connell, Michael. 1990. "The Faerie Queene, Book V." The Spenser Encyclopedia. Edited by A. C. Hamilton. Toronto. University of Toronto Pres. 28083.

Oram, William A. 1990. "Brigands." The Spenser Encyclopedia. Edited by A. C. Hamilton. Toronto. University of Toronto Press. 112-13.

Orgel, Stephen, ed. 1976. Michel de Marolles: Tableaux Du Temple Des Muses, Paris 1655 and Cesare Ripa: Iconologia or Moral Emblems, London 1709. The Renaissance and the Gods: A Comprehensive Collection of Renaissance Mythographies, Iconologies, and Iconographies, with a Selection of Works from The Enlightenment. New York. Garland.

Osgood, Charles G. 1931. "Comments on the Moral Allegory of The Faerie Queene." Modern Language Notes. 46. 502-07.

Owst, G. R. 1961. Literature And Pulpit in Medieval England: A Neglected Chapter in the History of English Letters and of the English People. Oxford. Basil Blackwell.

Padelford, Frederick M. 1924. "The Allegory of Chastity in The Faerie Queene." Studies in Philology. 21. 367-81.

Parker, Patricia. 1987. Literary Fat Ladies: Rhetoric, Gender, Property. London. Methuen.

Phillips, James E. 1970. "Renaissance Concepts of Justice and the Structure of The Faerie Queene, Book V." Huntington Library Quarterly. 33.2. 103-20.

Phillips, James Emerson. 1964. Images of a Queen: Mary Stuart in SixteenthCentury Literature. Berkeley. University of California Press.

Plato. 1908. The Republic. Trans. Benjamin Jowett. Vol. 2. 2 vols. Oxford. Clarendon Press.

Pliny. 1940. Natural History. Trans. H. Rackham. Vol. 3. 10 vols. Loeb Classical Library. London. Heinemann. 
Pollard, A. W. and G. R. Redgrave. 1986. A Short-title Catalogue of Books Printed in England, Scotland, \& Ireland and of English Books Printed Abroad 1475-1640. Vol. 1: A-H. 3 vols. London. The Bibliographical Society.

Prescott, Anne Lake. 1990. "Burbon." The Spenser Encyclopedia. Edited by A. C. Hamlton. Toronto. University of Toronto Press. 121.

Purkiss, Diane. 1996. The Witch in History: Early Modern and Twentieth-century Representations. London. Routledge.

Quinn, D. B. and K. W. Nicholls. 1976. "Ireland in 1534." A New History of Ireland. 3. Edited by T. W. Moody, F. X. Martin and F. J. Byrne. Oxford. Oxford University Press. 1-38.

Raleigh, Walter. 1596. The Discouerie of the Large, Rich, and Bewtiful Empire of Guiana. Performed in the Yeare 1595. By Sir W. Ralegh. London. R. Robinson.

Raleigh, Walter. 1965. Selected Prose and Poetry. Ed. Agnes M C Latham. London. Athlone.

Rich, Barnaby. 1609. A Short Survey of Ireland. Truely Discovering Who Hath Armed That People with Disobedience. London. N. O[kes] for B. Sutton and W. Barenger.

Rich, Barnaby. 1610. A New Description of Ireland: Wherein is Described the Disposition of the Irish. London. [W. Jaggard] for T. Adams.

Robbins, Rossell Hope. 1959. The Encyclopedia of Witchcraft and Demonology. London. Peter Nevill.

Rosinger, Lawrence. 1968. "Spenser's Una and Queen Elizabeth." English Language Notes. 6. 12-17.

Rowe, George E. 1989. "Privacy, Vision, and Gender in Spenser's Legend of Courtesy." Modern Language Quarterly. 50. 309-36.

Sander, Nicolas. 1877. Rise and Growth of the Anglican Schism. Completed by Edward Rishton. Trans. David Lewis. London. Burns and Oates.

Schleiner, Winfried. 1978. "Divina Virago: Queen Elizabeth as an Amazon." Studies in Philology. 75.2. 163-80.

Shaheen, Naseeb. 1976. Biblical References in The Faerie Queene. Memphis. Memphis State University Press.

Shakespeare, William. 1597. The Tragedie of King Richard the Second. London. V. Simmes for $A$. Wise. 
Shakespeare, William. 1604. The Tragicall Historie of Hamlet, Prince of Denmarke Newly Imprinted and Enlarged to Almost as Much Againe as it Was, According to the True and Perfect Coppie. London. [J. Roberts] for N. L[ing].

Shakespeare, William. 1608. M. William Shak-speare: His True Chronicle Historie of the Life and Death of King Lear and His Three Daughters. London. [N. Okes] for N. Butter.

Shakespeare, William. 1623. Mr. William Shakespeares Comedies, Histories, \& Tragedies. Published According to the True Originall Copies. London. Printed by Isaac Jaggard, and Ed. Blount.

Shakespeare, William. 1981. The First Part of King Henry the Sixth. Ed. Norman Sanders. Harmondsworth. Penguin.

Shakespeare, William. 1988. The Complete Works: Compact Edition. Ed. Stanley Wells, Gary Taylor, John Jowett, and William Montgomery. Oxford. Clarendon Press.

Shepherd, Simon. 1981. Amazons and Warrior Women: Varieties of Feminism in Seventeenth-century Drama. Brighton. Harvester.

Shepherd, Simon. 1989. Spenser. Atlantic Highlands, NJ. Humanities Press International.

Smith, Roland M. 1935. "Una and Duessa." Publications of the Modern Language Association of America. 50.3. 917-19.

Spenser, Edmund, ed. 1989. The Shorter Poems. Ed. William A Oram, Einar Bjorvand, Ronald Bond, Thomas H. Cain, Alexander Dunlop, Richard Schell. New Haven and London. Yale University Press.

Spenser, Edmund. 1758. The Faerie Queene. Ed. Ralph Church. Vol. 3. 4 vols. London. William Faden.

Spenser, Edmund. 1898. The Faerie Queene Book V. Ed. Kate M. Warren. Vol. 5. 6 vols. London. Constable.

Spenser, Edmund. 1909a. Spenser's Faerie Queene. Ed. J. C. Smith. Vol. 1: Books 1-3. 2 vols. Oxford. Clarendon Press.

Spenser, Edmund. 1909b. Spenser's Faerie Queene. Ed. J. C. Smith. Vol. 2: Books 4-7. 2 vols. Oxford. Clarendon Press.

Spenser, Edmund. 1910. The Faery Queene. Ed. G.W. Kitchin. Oxford. Clarendon Press.

Spenser, Edmund. 1918. The Faerie Queene Book V. Ed. Alfred B. Gough. Oxford. Clarendon Press. 
Spenser, Edmund. 1932. The Faerie Queene: Book One. Ed. Frederick Morgan Padelford. The Works of Edmund Spenser: A Variorum Edition. 1. Baltimore. Johns Hopkins.

Spenser, Edmund. 1933. The Faerie Queene: Book Two. Ed. Edwin Greenlaw. The Works of Edmund Spenser: A Variorum Edition. 2. Baltimore. Johns Hopkins.

Spenser, Edmund. 1935. The Faerie Queene: Book Four. Ed. Ray Heffner. The Works of Edmund Spenser: A Variorum Edition. 4. Baltimore. Johns Hopkins.

Spenser, Edmund. 1936. The Faerie Queene: Book Five. Ed. Ray Heffner. The Works of Edmund Spenser: A Variorum Edition. 5. Baltimore. Johns Hopkins.

Spenser, Edmund. 1943. The Minor Poems Volume One. Ed. Charles Grosvenor Osgood, Henry Gibbons Lotspeich, and Dorothy E. Mason. The Works of Edmund Spenser: A Variorum Edition. 7. Baltimore. Johns Hopkins.

Spenser, Edmund. 1947. The Minor Poems Volume Two. Ed. Charles Grosvenor Osgood, Henry Gibbons Lotspeich, and Dorothy E. Mason. The Works of Edmund Spenser: A Variorum Edition. 8. Baltimore. Johns Hopkins.

Spenser, Edmund. 1949. Prose Works. Ed. Rudolf Gottfried. The Works of Edmund Spenser: A Variorum Edition. 10. Baltimore. Johns Hopkins.

Spenser, Edmund. 1977. The Faerie Queene. Ed. A. C. Hamilton. Annotated English Poets. London. Longman.

Spenser, Edmund. 1997. A View of the State of Ireland. Ed. Andrew Hadfield, Willy Maley. Oxford. Blackwell.

Staton, Walter F. 1966. "Italian Pastorals and the Conclusion of the Serena Story." Studies in English Literature: 1500-1900. 6.1. 35-42.

Strabo. 1923. Geography. Trans. Horace Leonard Jones. Vol. 2. 8 vols. Loeb Classical Library. London. Heinemann.

Strong, Roy. 1977. The Cult of Elizabeth: Elizabethan Portraiture and Pageantry. London. Thames and Hudson.

Strong, Roy. 1987. Gloriana: The Portraits of Queen Elizabeth I. London. Thames and Hudson.

Stubbs, John. 1579. The Discouerie of a Gaping Gulf Whereinto England is Like to be Swallowed By an Other French Mariage. [Anon]. London. H. Singleton for W. Page.

Summers, Montague. 1926. The History of Witchcraft and Demonology. London. Routledge and Kegan Paul. 
Tayler, Edward William. 1964. Nature and Art in Renaissance Literature. New York. Columbia University Press.

Thomas, Keith. 1971. Religion and the Decline of Magic: Studies in Popular Beliefs in Sixteenth and Seventeenth Century England. London. Weidenfeld and Nicolson.

Todd, Henry John. 1805. The Works of Edmund Spenser. Vol. 3. 8 vols. London. F. C. and J. Rivington, T. Payne, Cadell and Davies, and R. H. Evans.

Tonkin, Humphrey. 1972. Spenser's Courteous Pastoral: Book Six of the Faerie Queene. Oxford. Clarendon.

Upton, John. 1987a. Notes on the Faery Queen. Ed. John G. Radcliffe. Vol. 1. 2 vols. Satire and Sense. New York. Garland.

Upton, John. 1987b. Notes on the Faery Queen. Ed. John G. Radcliffe. Vol. 2. 2 vols. Satire and Sense. New York. Garland.

Van Roey, Jan L. R. and Tilde A. Sankovitch. 1993. "Antwerp." Encyclopaedia Britannica. Macropaedia: 13. Edited by Robert McHenry. Chicago. Encyclopaedia Britannica Incorporated. 805-07.

Vickers, Nancy J. 1981. "Diana Described: Scattered Woman and Scattered Rhyme." Critical Inquiry. 8.2. 265-79.

Vickers, Nancy. 1985. “The Blazon of Sweet Beauty's Best: Shakespeare's Lucrece.” Shakespeare and the Question of Theory. Edited by Patricia Parker and Geoffrey Hartman. New York. Methuen. 95-115.

Warner, Marina. 1990. Alone of All Her Sex: The Myth and Cult of the Virgin Mary. London. Pan.

Warner, Marina. 1995. From the Beast to the Blonde: On Fairy Tales and Their Tellers. London. Vintage.

Warton, Thomas. 1762. Observations on the Fairy Queen of Spenser. Vol. 2. 2 vols. London. R. and J. Dodsley.

Waters, D. Douglas. 1966. "Errour's Den and Archimago's Hermitage: Symbolic Lust and Symbolic Witchcraft." English Literary History. 33.3. 279-98.

Waters, D. Douglas. 1970. Duessa as Theological Satire. Columbia. University of Missouri Press.

Wegg, Jervis. 1916. Antwerp 1477-1559: From the Battle of Nancy to the Treaty of Cateau Cambrsis,. London. Methuen.

Wells, Stanley, Gary Taylor, John Jowett and William Montgomery. 1987. William Shakespeare: A Textual Companion. Oxford. Clarendon Press. 
White, Hayden. 1972. "The Forms of Wildness: Archaeology of an Idea." The Wild Man Within: An Image in Western Thought From the Renaissance to Romanticism. Edited by Edward Dudley and Maximillian E. Novak. Pittsburg. University of Pittsburgh Press. 3-38.

Williams, Arnold. 1967. Flower on a Lowly Stalk: The Sixth Book of the Faerie Queene. Michigan. Michigan State University Press.

Williams, Gordon. 1994. A Dictionary of Sexual Language and Imagery in Shakespearean and Stuart Literature. Vol. 2. 3 vols. London. Athlone.

Williamson, Paul, ed. 1986. The Medieval Treasury: the Art of the Middle Ages in the Victoria and Albert Museum. London. Victoria and Albert Museum.

Willis, Deborah. 1995. Malevolent Nurture: Witch-Hunting and Maternal Power in Early Modern England. Ithaca, New York. Cornell University Press.

Wither, George. 1975. A Collection of Emblems, Ancient and Modern (1635). Introduction by Rosemary Freeman. Bibliographical notes by Charles S. Hensley. Columbia, Carolina. University of South Carolina Press.

Woodbridge, L. 1986. "Amoret and Belphoebe: Fairy Tale and Myth." Notes and Queries. 33.3. 340-42.

Yates, Frances A. 1947. "Queen Elizabeth As Astraea." Journal of the Warburg and Courtauld Institutes. 10. 27-82.

\section{INDEX}

Acrasia, 10, 37, 38, 39, 40, 43, 45, 46, 47, 48, 49, 54, 59, 61, 63, 73, 80, 81, 83, 84, $85,86,132,135,137,138,140,142,145,149,155$

"Act of Union" by Seamus Heaney, 23

Adam and Eve, 21

Aemylia, 94, 158 
Aesop, 24

Alciatus, Andreas, 29

Alcina, 38

Alma, 46, 47, 48, 84, 92, 143, 155

Alpers, Paul J., 154

Amavia, 40, 45, 47, 48, 50, 81, 137

Amoret, 57, 58, 59, 60, 92, 93, 94, 95, 120, 157

Amphitrite, 96

An Act for the English Order, Habit, and Language, 162

ancient Britain, 77, 78, 93

Anderson, Judith, 106

Anothomy of Ireland, The by Barnaby Rich, 91

anthropomorphic reliquaries, 102, 109, 111

Antichrist, 32, 42, 102, 103, 110

anti-Protestant polemic, 55

Apollo, 58

Apollodorus, 159

Arcadia by Phillip Sidney, 119

Archimago, 134, 135, 144

Arens, W., 61, 64

Argante, 60, 61, 62, 63, 64, 65, 92, 130, 147

Ariosto, 38

Arlo hill, 147

Armida, 38

Artegall, 21, 38, 50, 67, 89, 96, 97, 101, 106, 107, 108, 110, 124, 125, 126, 137, 141, $142,144,155,161$ 
Arthur, 1, 84, 85, 86, 92, 94, 106, 107

Astraea, 74, 143, 156

Astrophel and Stella by Phillip Sidney, 66

Ate, 45, 86, 158

Bagenal, Mabel, 94, 98, 120

Barber, Malcolm, 41

Belge, 105, 124

Belphoebe, 55, 57, 58, 59, 60, 61, 93, 94, 95, 133, 134, 143, 156, 158

Bennett, Josephine Waters, 20

Berleth, Richard J., 130, 161

Bible, 12, 59, 69, 73, 85

Geneva, 20, 32, 42, 102, 152, 156

Bingham, Richard (governor of Connaught), 155

Blackwood, Adam, 55

Blakeney, E. H., 103

Blandamour, 66

Blenerhasset, Thomas, 8, 79, 87, 157

Blount, Elizabeth, 62

Boleyn, Anne, 56, 57, 60, 61, 62, 63, 68, 72, 75

Boleyn, Elizabeth, 56

Boleyn, Thomas, 56

"Booke of Questions and Answars Concerning the Warrs or Rebellions of the Kingdome of Ireland, A", 90, 118

Bower of Bliss, 37, 38, 49, 50, 81, 82, 83, 86, 132, 138, 154

Brady, Ciaran, 151

Braggadocchio, 67, 138 
Fitzpatrick, Joan. 2000b. Irish Demons: English Writings on Ireland, the Irish and Gender By Spenser and His Contemporaries. Lanham. University Press of America.

Brehon law, 99

Brief Note of Ireland, A, 50, 51, 78, 85, 87, 91, 95, 118, 151

Brigants, the, 114, 115, 117, 118, 119, 123, 126, 160

Briggs, Robin, 159

Brink, Jean, 52, 151

Britannia by William Camden, 43, 153

Britomart, 96, 97, 106, 107, 133, 134, 143, 155, 156

Brutus, $47,77,78$

Bullough, Geoffrey, 53

Burbon, 123, 124, 125, 142

Burghley, Lord, 17, 46

Burowe, Lord Deputy, 4

Butlin, R. A., 79

Bynum, Caroline Walker, 108

Cain and Abel, 115

Calepine, 104, 122

Camden, William, 21, 25, 43, 101, 158

Campion, Edmunde, 27

cannibalism, 2, 29, 44, 64, 94, 122

Canny, Nicholas, 2, 64, 115, 151, 161

Carroll, Clare, 158

cartography of early modern Ireland, 82

Cartwright, Thomas, 2

Catherine de Medici, 46

Catholic League, 108, 159, 160 
Chang, H. C., 121

chastity, virtue of, $44,47,55,57,58,59,60,62,63,64,67,72,75,93,99,119,120$, $125,130,133,134,138,145,148,155,158$

Cheney, Donald, 92

Christ, 6, 28, 58, 61, 69, 109, 156

Chronicle of Briton Kings, 77, 78

Chronicles by Raphael Holinshed, 27, 39, 43, 44, 45

Chrysogone, 57, 58, 60, 61, 94

Church, R. W., 9, 19, 21, 31, 33, 35, 57, 58, 60, 62, 63, 66, 67, 68, 103, 126, 130, 137, 139, 154, 156

Circe, 38, 45

Claribell, 117

Compendium Maleficarum by Francesco Maria Guazzo, 40

Coridon, 116

courtesy, virtue of, 113, 119, 122, 123, 135

Cromwell, Oliver, 87

Cynthia, 130, 131, 143, 144, 146, 147

Daemonologie by James 1, 154

Danae, myth of, 58

Davies, John, 2, 5, 8, 29, 30

Dawtrey, Nicholas, 157

degeneration, $10,19,26,38,45,46,47,59,62,63,84,87,90,98,99,104,116$, $117,123,129,131,132,134,135,137,138,140,141,147,148,149$

of knights, 137

of the landscape, 131

of the Old English, 38, 129, 139

of the world, 131, 144 
Fitzpatrick, Joan. 2000b. Irish Demons: English Writings on Ireland, the Irish and Gender By Spenser and His Contemporaries. Lanham. University Press of America.

DeNeef, A. Leigh, 104, 161

Derricke, John, 2, 39, 117, 118, 154, 159, 160, 165

Desmond rebellion, 27

Desmond, Earl of, 1, 159

Detraction, 45, 57, 158

Diana, 58, 129, 130, 131, 143, 144, 147, 148, 149

Direction for the Plantation in Ulster, $A$ by Thomas Blenerhasset, 8

Discourse of Ireland, $A$ by Luke Gernon, 6, 22, 151

Discoverie of the True Causes Why Ireland was Never Entirely Subdued, A by John Davies, 5, 29

Discovery of a Gaping Gulf, The by John Stubbs, 46

Discovery of the Large, Rich, and Bewtiful Empire of Guiana, The by Raleigh, Walter, 97

Donne, John, 23

dragon, the, 23, 78, 131, 132, 136

Draper, John W., 58, 59

Druon Antigoon, 110

Duessa, 10, 19, 26, 31, 32, 33, 34, 35, 38, 40, 42, 45, 46, 59, 61, 63, 73, 83, 84, 86, $87,91,99,105,107,133,134,135,136,137,138,145,161$

Duke of Anjou, 46

Dunseath, T. K., 158, 159

Dutch legend, 110

E. K., 14, 152

Earth as mother of Typhoeus, 60, 73

Echidna, 26

Eden, 21, 131, 132, 154

Elizabeth 1, 1, 19, 47, 143, 152, 156 
alleged illegitimacy of, 56

as mother of the English Church and people, 9, 48

as Protestant substitute for the Virgin Mary, 59

childless state, 63

emblems, 23, 28, 29, 37, 39, 50, 123

enclosure of land, 6

England's Eliza by Richard Niccol, 24

Envy, 45, 57, 158

Epithalamion by Edmund Spenser, 105

Error, 19, 24, 25, 26, 27, 28, 31, 35, 63, 87, 136, 138, 153, 157

her brood as Catholics, 24

her cave or den, $30,63,84,119$

Essex, Earl of, 1

Eucharist, the, 30

Eudoxus, 4, 7, 50, 51, 52, 53, 85, 110, 131, 139, 140, 141, 142, 148

Ewen, C. L'Estrange, 41, 154

Excess, 45, 132

Fairyland, 9, 64, 79, 80, 98, 107, 132, 149

Falkiner, C. Litton, 6, 22, 25, 120, 153

Fall of Eden, 131

False Florimell, 59, 65, 66, 67, 86, 104, 105, 134, 135, 138, 156

creation of, 65

False Una, 134, 135

famine, $27,43,50,96$

Faunus, 148 
fens of Allan, 85

Ferraugh, 138

Ferryman, the, 82

Fidessa, 33

fleur-de-lis, 124

Flourdelis, 105, 114, 123, 124, 125, 126, 142, 157, 160

Fogarty, Anne, 117, 120, 121, 160

Forester, the, 65, 87, 88, 89, 95, 98

Fortune, 130

fostering, 9, 11, 25

Fradubio, 33, 34, 35, 38, 40, 83, 134, 136

Fraelissa, 33, 34, 40, 134

France, 61, 74, 105, 114, 124, 160

Freud, Sigmund, 16

Frye, Roland Mushat, 25

Gaelic poets, 39

Gainsford, Thomas, 42, 79, 81, 83, 87, 88, 89, 90

genocide, 18, 143

George, Saint, 20, 137

Gernon, Luke, 6, 22, 120, 124, 151

Geryoneo's monster, 26

glib, the, 24, 153

Gloriana, 47, 55, 143

Glory of England, The by Thomas Gainsford, 42

Grantorto, 21, 101, 110, 123, 125 
Fitzpatrick, Joan. 2000b. Irish Demons: English Writings on Ireland, the Irish and Gender By Spenser and His Contemporaries. Lanham. University Press of America.

Gray, M. M., 92, 120, 121

Greek romance, 58, 117, 160

green sickness, 22

Greenblatt, Stephen, 50, 81, 156

Greenlaw, Edwin, 158

Grey, Lord Arthur, 1

Grille, 45, 135, 140

Guazzo, Francesco Maria, 40

guerrilla warfare, 84, 88

Guiana, 23, 97, 120, 172

Guile, 133

Guise, house of, 108

Guizor, 101, 108

Gurgunt, 78

Guyon, 37, 38, 39, 45, 47, 48, 49, 50, 51, 53, 54, 77, 81, 82, 83, 84, 138, 144, 148

Hackett, Helen, 21, 59, 69, 143

Hadfield, Andrew, 2, 52, 118, 119, 123, 143, 144, 151, 152, 153, 158, 159

and John McVeagh,, 123

Hamilton, A. C., 33, 91, 98, 101, 168

Harvey, Gabriel, 161

Hawkins, Harriet, 37

Heliodorus, 58, 117, 155

Hellwis, Edward, 21

Henley, Pauline, 56, 80, 153, 159

Henri of Navarre, 142, 160 
Henry 8, 57, 61, 141, 155

Henry, the duc de Guise, 159

Highley, Christopher, 155

Hilliard, Nicholas, 28

History of Ireland, A by Edmunde Campion, 27

Holiness, 20, 119, 137, 161

Holinshed, Raphael, 27, 39, 43, 44, 45, 54

Homer, 38, 45

Hooker, John, 27, 44

Hooker, Richard, 83, 157

Hough, Graham, 158

House of Holiness, 136

House of Pride, 132, 137

Huddibras, 48

Hughes, Art J., 39

hybridity, 17, 25, 26, 94, 123, 153

Iconologia by Cesare Ripa, 23

icons, 30,73

idolatry, 14, 66

Image of Ireland, The by John Derricke, 117, 159, 160

Immaculate Conception, 58, 59

Impatience, 158

Impotence, 158

incest taboo, 56, 60, 61, 63, 64

Infidels, 13, 14, 31, 103 
inherent nobility, 113, 116, 117, 119, 123

Iniquity (Queen of Hell), 102

intermarriage, 9

Ireland

as a sister to England, 8

as a victim, 7, 23

as a wasteland, 149

as cursed, 81

climate of, 80,83

geography of, 80

Irenius, 4, 5, 9, 10, 11, 13, 21, 25, 26, 27, 29, 34, 38, 39, 44, 50, 51, 52, 53, 57, 81, $85,86,89,91,93,94,98,101,103,107,110,111,114,115,116,117,118,119$, $121,129,131,132,133,139,140,141,142,143,146,148,153,154,160$

Irish

as cannibals, 11, 27, 29, 30, 64, 92, 93, 104, 123, 126, 156, 160, 161

as cursed, 4

as savage, $2,15,27,29,52,88,98,113,152$

as serpents, 24,35

as weeds, 5, 6

baptismal rites, 39

childbirth, 11, 24, 25

common ancestry with Scots, 53, 116

compared to beasts, 65

diet, 43, 92

language, 24, 25, 38, 143

law against their clothing, 141 
mothers/foster mothers, $7,11,43,48,140$

rebellion, 5, 6, 11, 12, 13, 14, 15, 22, 37, 38, 42, 44, 46, 54, 86, 87, 90, 91, 92, 95 , $96,99,101,108,110,111,113,114,118,121,124,129,130,131,132,143,144$, $145,146,147,149,161$

rivers, 98

war cries, 37, 85, 139

wolves, 87,88

Irish landscape

impassability of, $79,81,98,99,114$

the interior, $77,80,87,98,157$

Islam, 41

Italian Romance, 38

Itinerary, An by Fynes Moryson, 65, 153

James 1 of England (6 of Scotland), 33, 41, 154

Jardine, Lisa, 156

Jenkins, Raymond, 154

Jewel, John, 83, 157

Joan La Pucelle, 57, 72, 75

Jones, Ann Rosalind, 24

Jonson, Ben, 42

Jove, 58, 129, 144, 145, 146

Joyce, P. W., 98

Judson, Alexander, 153

Jupiter, 58

justice, virtue of, 12, 13, 14, 50, 101, 105, 106, 107, 108, 110, 111, 124

Katherine of Aragon, 56, 60 
Fitzpatrick, Joan. 2000b. Irish Demons: English Writings on Ireland, the Irish and Gender By Spenser and His Contemporaries. Lanham. University Press of America.

Kermode, Frank, 31

kerns, 24, 87

Killarney, lakes as inspiration for the Bower of Bliss, 80

Kitchin, G. W, 78

Klein, Bernhard, 152, 157

Klein, Melanie, 11

Lady Meed, 102, 159

Latona, myth of, 58

Lemmi, C. W., 158

Leslie, John, 55

Letter to Raleigh by Edmund Spenser, 16, 55, 143

Lewis, C. S., 106

Lucifera, 132

lunar imagery, 143, 149

Lupton, Julia Reinhard, 148

lust, 34

Lust, figure of, 93, 94, 95, 120, 122, 158

Mac Art, Brian, 44

Mac Dhomhnaill clan, 39

MacCaffrey, Wallace, 46

MacFarlane, Alan, 32

Magennis clan, 39

Malecasta, 132, 156

Maleger, 84, 85, 86, 92, 144

Maley, Willy, 2, 3, 9, 15, 18, 151, 152, 159, 160 
Mandeville, John, 156

mantle, the, 24, 133, 141, 153

maps of Ireland, 82, 152

Mares, F. H., 42

Marian iconography, 59, 61

Mary 1, 1, 49, 66

Mary Queen of Scots, 33, 46, 49, 55, 66, 101, 171

Mass, the Catholic, 32, 38, 83, 84, 121

Maxwell, Constantia, 162

McCabe, Richard, 13, 27, 30, 31, 33, 39, 103, 158, 159

McCracken, Eileen, 79

McNeir, Waldo F., 121, 160

Medina, 46, 47, 48, 49, 59, 143

Meliboe, 114, 116

menstrual blood, 42

Mercilla, 107, 143

Mercury, 104, 144, 146

mercy/pity, danger of, $9,14,28,50,51,56,96,107,108,133$

Millican, C. Bowie, 152

Milward, Peter, 56

miscegenation, 9, 94, 98, 114, 120, 123, 126, 132, 135

Molanna, 129, 131, 144, 147, 149

Montrose, Louis, 23, 115

Morgan, Hiram, 90, 94, 118, 155, 157, 158

Mortdant, 38, 137 
Moryson, Fynes, 24, 25, 41, 65, 91

Mother Hubbard's Tale by Edmund Spenser, 46

Mountjoy, Lord Deputy, 25

Munera, 50, 101, 102, 103, 104, 105, 106, 107, 108, 109, 110, 111, 126, 158, 159, 161

Munster plantation, 1, 2

Munster rebellion, 3, 9, 12, 16, 56, 92, 118

Muslim mythology, 103

Mutabilitie, 129, 130, 131, 135, 140, 143, 144, 145, 146, 147, 148, 149

Nature, 129, 131

Neff, Merlin L., 158, 159

Neill, Michael, 152

Nelson, William, 106

Neoplatonism, 20, 35, 59, 60

Neptune, 96

Netherlands, the 101,110

New Description of Ireland, A by Barnaby Rich, 15, 25

New English Ideology, 3

New Testament Revelation of St. John, 19, 20, 21, 35, 152

New World, 22, 30, 124

Niccol, Richard, 24

Nine Years War, 2, 119, 158

Obrien, Murrogh, 27

Occasion, 45, 158

"Ocean to Cynthia" by Walter Raleigh, 143

Odyssey, The by Homer, 38, 45, 82 
Fitzpatrick, Joan. 2000b. Irish Demons: English Writings on Ireland, the Irish and Gender By Spenser and His Contemporaries. Lanham. University Press of America.

Oge, Rory, 11, 159

Ollyphant, 60, 62, 63, 92

O'Neill clan, 37, 38, 39, 45

O'Neill, Hugh, (the Earl of Tyrone), 94, 95, 98, 119, 120, 123, 158, 161

Orgoglio, 32, 42, 161

Orlando Furioso by Ludovico Ariosto, 38

Ormond and Ossory, Earl of, 17

Osgood, Charles G., 92

Owst, G. R., 102

Padelford, Frederick M., 95

paganism, 13, 30, 31, 103, 132, 138

Pale, the, 1, 117

Palmer, the, 47, 82, 83, 138, 148

Paridell, 66, 156

pastoralism, 113, 114, 115, 116, 117, 119, 121, 149

Pastorella, 113, 114, 115, 116, 117, 119, 120, 121, 122, 123, 126, 157

pelican, the, 28,29

Persons, Robert, 56

Petrarchan rhetoric, 21, 58, 65, 66, 69, 71, 96, 97, 101, 102, 103, 105, 109, 111

Phaedria, 149

Phillips, James Emerson, 55, 56

Phoebe, 143, 146

Placidas, 94

planter rhetoric, 3,5

Pliny, 27 
Poeana, 106

Pollente, 89, 101, 102, 103, 108, 110, 158, 159

Pope, the, 12, 15, 24, 32, 42, 62, 102, 103, 125

postcolonial theory, 17

poststructuralism, 16

primogeniture, 99, 161

Purkiss, Diane, 32, 46, 154

Radigund, 50, 97, 105, 107, 141, 143, 156

Raleigh, Walter, 16, 23, 95, 97, 98, 120, 124, 162

rebellion as a sickness, 91, 121

Red Hand of Ulster, 37, 39, 53

Redcrosse, 20, 23, 24, 30, 33, 34, 40, 83, 137, 138

Reformation, 6, 9, 12, 20, 55, 57, 59, 61, 91, 111, 133

relic worship, 108, 111

Rich, Barnaby, 2, 15, 24, 25, 65, 91

Ripa, Cesare, 23

Rise and Growth of the Anglican Schism by Nicolas Sander, 55, 56, 57, 61, 62, 63, $67,68,70,72,75$

Rishton, Edward, 56

Rosinger, Lawrence, 20, 152

Ruddymane episode, 37, 38, 39, 40, 45, 48, 49, 51, 52, 53, 148

Saluage Nation

the ignorant, 30, 31, 66, 122, 138, 157

the malevolent, $93,113,114,121,122,157,160$

Sander, Nicolas, 55, 56, 57, 61, 62, 63, 67, 68, 69, 70, 72, 75

Sanders, Norman, 72 
Sansfoy, 138

Sansjoy, 138

Sansloy, 48, 83, 138

Satan, 12, 23, 32, 40, 41, 67, 102

Schleiner, Winfried, 156

Scotland, 33, 53, 116, 154, 159, 160

Scythian, alleged origins of the Irish, 27, 37, 44, 53, 115, 116, 139

Semper Eadem as Elizabeth's motto, 20, 22

Sergis, Sir, 124

Shakespeare, William, 24, 28, 29, 51, 52, 53, 54, 55, 57, 68, 69, 70, 71, 72, 73, 74, $75,120,123,153,155,156,157,167$

2 Henry 6, 157

All is True (King Henry 8), 57, 68, 70, 72

Comedy of Errors, The, 157

Hamlet, 28, 29

Henry 5, 157

King Lear, 28

Macbeth, 51, 53, 54

Othello, 156

Richard 2, 24, 28, 157

Tempest, The, 120

Shepheardes Calender, The by Edmund Spenser, 14, 46, 59, 69

Shepherd, Simon, 97, 155

Short Survey of Ireland, A, by Barnaby Rich, 65

Sidney, Henry, 83

Sidney, Phillip, 66, 119, 158 
Slander, 158

Smerwick, 27, 44, 56, 153, 159

Smith, Roland M, 33

Smith, Thomas, 1

Southwell, Robert, 52

Spain, 24, 101, 110, 125, 159, 160

Squire of Dames, the, 60

St. Patrick, 23

Stallybrass, Peter, 24

Stanyhurst, Richard, 43, 45

Staton, Walter, 121

Strabo, 27, 154

Strong, Roy, 21, 28, 156

Stubbs, John, 46

"Supplication of the Blood of the English most Lamentably Murdered in Ireland, Cryeng out of the Yearth for Revenge, The", 2, 3, 4, 5, 6, 8, 11, 12, 13, 14, 15, 16, $18,39,51,74,81,86,129,130,132,133,134,135,136,146$

surnames

imposition of English upon the Irish, 142

Old English adopting Irish, 7

Surrender and regrant policy, 161

Talos as source for Talus, 159

Talus, 38, 50, 86, 101, 102, 104, 106, 107, 108, 109, 111, 144, 155, 159

Tasso, 38

Tayler, William, 119

temperance, virtue of, 84, 132, 133, 136, 161 
Thames and the Medway, marriage of, 96, 98

Thomas, Keith, 40, 154

Throckmorton, Elizabeth, 95

Timias, 88, 89, 90, 95

Titans, 60, 61, 94, 130, 147

Todd, H. J., 51

"To his Mistress Going to Bed", by John Donne, 23

tolls, 103, 110, 158

Tonkin, Humphrey, 119, 160

transhumance, 115, 116

transubstantiation, 4, 30, 122

travel literature, 77

Travels by John Mandeville, 156

Typhaon, 26

Typhoeus, 60, 61, 62, 64

Ulster, as a young niece of England, 8

Una, 19, 20, 21, 22, 23, 24, 30, 31, 33, 34, 35, 40, 46, 47, 49, 58, 65, 66, 78, 110 , $122,131,132,133,134,136,138,142,143,152,160$

Upton, John, 37, 60, 95

usquebaugh, 43, 154

Van Roey, Jan L. R., 110

venereal disease, 34, 91

Venus, 73, 134, 155

Verdant, 43, 137, 141

Vickers, Nancy, 103, 104, 105, 161 
View of the Present State of Ireland, A by Edmund Spenser, 2, 3, 4, 5, 7, 8, 9, 11 , $13,15,16,19,21,25,26,27,29,34,37,38,39,41,44,47,50,51,52,53,54,57$, $81,85,86,89,91,93,94,96,98,101,103,107,110,111,114,115,116,117,118$, $119,120,121,122,129,130,131,132,133,134,136,137,139,141,142,144,146$, $148,149,151,153,154,159,160$

manuscripts of, 151

Virgin Mary, 47, 48, 58, 59, 61, 69, 73, 155, 166

virginity, symbols of, $20,21,47,58,65,82,97,105,155$

Wandring Islands, 82, 83

Wandring Wood, 30, 84

Ware, James, 151

Warner, Marina, 58

Warton, Thomas, 19

Waters, D. Douglas, 32

White, Hayden, 93

Whore of Babylon, the, 31, 32, 35, 41, 102, 138, 161

Wild Man, the, 93, 158

Williams, Arnold, 79

Williamson, Paul, 108, 109

Willis, Deborah, 43

Wilson, E. C., 156

witches and witchcraft

as metaphor for Catholic seduction, 32, 34, 38, 145

cannibalism, 40, 41

continental conception of, 40

devil marks, 35, 42

familiars, 42, 43 
Fitzpatrick, Joan. 2000b. Irish Demons: English Writings on Ireland, the Irish and Gender By Spenser and His Contemporaries. Lanham. University Press of America.

frustrating sexual relationships, 40

harm done to children by, $7,11,25,26,27,40,41,44,51,53,63,94,140$

hunting of, 31

interference with the weather, 40, 83

Wither, George, 28

Woman Clothed with the Sun, the, 21

woman-as-land trope, 22, 71, 124, 153

Woodbridge, Linda, 58

woods, Irish

as refuge for rebels, $30,79,80,81,87,88,89,90,93,98,118,138$

economic potential of, $30,79,81,87$

Yates, Frances, 143, 156 